UNIVERSIDADE DE SÃO PAULO

FACULDADE DE EDUCAÇÃO

Maria Eloisa Velosa Mortatti

\title{
GESTÃO DEMOCRÁTICA COMO UM PROCESSO DE EDUCAÇÃO PARA A CIDADANIA
}




\section{GESTÃO DEMOCRÁTICA COMO UM PROCESSO DE EDUCAÇÃO PARA A CIDADANIA}

Dissertação apresentada como requisito parcial à obtenção do título de Mestre em Educação, Programa de Pós Graduação em Educação, Mestrado. Área: Estado, Sociedade e Educação. Faculdade de Educação. Universidade de São Paulo. Orientadora: Prof $^{a} \operatorname{Dr}^{a}$ Lisete Regina Gomes Arelaro.

São Paulo

2006 
AUTORIZO A REPRODUÇÃO E DIVULGAÇÃO TOTAL OU PARCIAL DESTE TRABALHO, POR QUALQUER MEIO CONVENCIONAL OU ELETRÔNICO, PARA FINS DE ESTUDO E PESQUISA, DESDE QUE CITADA A FONTE.

Ficha Catalográfica elaborada pela

Biblioteca da Faculdade de Educação - USP - SP

Mortatti, Maria Eloísa Velosa

Gestão Democrática Como um Processo de Educação Para a Cidadania/ Maria Eloísa Velosa Mortatti - São Paulo, 2006.

Dissertação - Programa de Pós Graduação em Educação, Mestrado. Área de Concentração: Estado, Sociedade e Educação. Faculdade de Educação. Universidade de São Paulo.

p. 156

1. Cidadania e Educação 2.Estado e educação 


\section{FOLHA DE APROVAÇÃO}

Maria Eloísa Velosa Mortatti

“Gestão Democrática como um processo de Educação para a Cidadania”

Dissertação apresentada ao programa de Pós Graduação em Educação, da Faculdade de EducaçãoUniversidade de São Paulo, como requisito parcial à obtenção do título de Mestre

Área: Estado, Sociedade e Educação.

Aprovado em:

\section{Banca Examinadora}

Prof $^{\mathrm{a}}$. Dr ${ }^{\mathrm{a}}$.

Instituição:

Assinatura:

Prof $^{\mathrm{a}}$. Dr ${ }^{\mathrm{a}}$

Instituição:

Assinatura:

Prof $^{\mathrm{a}} \cdot{ }^{D} \mathbf{r}^{\mathrm{a}}$

Instituição:

Assinatura: 


\section{AGRADECIMENTOS}

A Deus, que é, segundo Paulo Leminski, "tudo aquilo (ou aquilo tudo) que faz a gente viver, com plenitude mental e espiritual, vida boa de ser vivida: chame-se Ra, Amon, Aton, Zeus, Iavé, Jesus, Xangô, Buda ou revolução. O sentido: a interpretação final do gesto de existir. O para quê. E o por quê”.

À Profa. Dra. Lisete Regina Gomes Arelaro, por sua amizade, pela orientação sempre segura, pelos ensinamentos preciosos e também por acreditar e confiar a responsabilidade para a realização dessa pesquisa.

À Prof. Dra. Maria Victória de Mesquita Benevides e ao Prof. Dr. Vitor Henrique Paro que, participando da Banca de Exame de Qualificação, apresentaram significativas contribuições a este trabalho.

À Prefeitura Municipal de Araraquara, em especial à Equipe da Coordenadoria de Participação Popular, que foi fundamental para a realização dessa pesquisa.

Aos meus colegas de orientação, pelo apoio e discussão dos trabalhos, com quem tive momentos que, além de muito alegres, foram de grande aprofundamento teórico.

Aos amigos, que tiveram a paciência de agüentar minhas lamúrias, empolgações, ansiedades e inquietações no decorrer de todo esse percurso.

À Marcela e ao Arnaldo que me ajudaram de maneira significativa, fazendo a revisão deste trabalho e ajudando nas questões paulistanas.

À Minha mãe Marlene, meu pai Oswaldo e os meus irmãos Antonio e Teresa que tiveram a paciência nesse período e me deram todo o incentivo para prosseguir. 


\section{LISTA DE QUADROS, TABELAS E GRÁFICOS}

QUADRO 1. Ciclo do Orçamento Participativo

TABELA 1. Participação por reuniões do OP 76

TABELA 2. Participação total do OP 76

$\begin{array}{ll}\text { TABELA 3. Renovação de participantes } & 78\end{array}$

TABELA 4. Participação total por etapa de reuniões 80

TABELA 5. Perfil dos Delegados do Orçamento Participativo 86

TABELA 6 Participação em outros espaços 93

TABELA 7. Espaços de participação $\quad 94$

TABELA 8. Participação em mais de um espaço 95

GRÁFICO 1. Participação total nas regiões $\quad 74$

GRÁFICO 2. Participação OP 2001/04 79

GRÁFICO 3. Média de Participantes por reunião/ano 79

GRÁFICO 4. Participação OP 2001/04 por região

GRÁFICO 5. Participantes por Gênero 82

GRÁFICO 6. Participantes por Etnia 83

GRÁFICO 7. Participantes por Faixa Etária 83

GRÁFICO 8. Participantes do OP por Escolaridade 84

GRÁFICO 9. Variação de Escolaridade $\quad 84$

GRÁFICO 10. Total de Participantes que participam em outros espaços em $2004 \quad 93$

GRÁFICO 11. Número de Participantes por espaços 95 


\section{LISTA DE ABREVIATURAS E SIGLAS}

APP Agentes de Participação Popular

CEPAM Centro de Estudos e Pesquisa de Administração Municipal

COP Conselho do Orçamento Participativo

CPP Coordenadoria de Participação Popular

CRC Coordenação das Relações com a Comunidade

CROPs Coordenadores Regionais do OP

CTs Coordenadores Temáticos

ES Espírito Santo

GAPLAN Gabinete de Planejamento

IBGE Instituto Brasileiro de Geografia e Estatística

IDH-M Índice de Desenvolvimento Humano de Municípios

MG Minas Gerais

NPP Núcleo de Participação Popular

ONG `S Organizações Não Governamentais

OP Orçamento Participativo

PCdoB Partido Comunista do Brasil

PPS Partido Popular Socialista

PSB Partido Socialista Brasileiro

PT Partido dos Trabalhadores

RS Rio Grande do Sul

SP São Paulo

UBS Unidades Básicas de Saúde

UNESP Universidade Estadual de São Paulo

UNIARA Centro Universitário de Araraquara

UNIP Centro universitário Paulista 


\section{RESUMO}

A democracia participativa vem ganhando ênfase no âmbito das administrações públicas. A experiência de maior destaque, até mesmo internacional, é a de Orçamento Participativo, no qual a população delibera sobre as prioridades a serem inseridas no orçamento público. Estudos têm destacado que essas práticas possibilitam aos seus participantes realizarem um exercício da cidadania ativa, desenvolvendo cada vez mais os espaços de participação popular característicos de sociedades democráticas - Freire, Benevides, Gohn, Pontual. Admite-se, também, que essas experiências de Orçamento Participativo vêm contribuindo para o desenvolvimento e integração de outras práticas participativas. Esta pesquisa teve por objetivo estudar o instrumento de gestão democrática denominado “Orçamento Participativo”, implementado pela Administração Municipal da Prefeitura de Araraquara/SP, trabalhando com a hipótese de que esse mecanismo de participação popular contribui para a educação para a cidadania da parcela de munícipes que participam desse processo, incentivando que estes se insiram em outros espaços de participação e de controle social. O que se pode perceber é que essa participação colabora, de fato, para a formação cidadã, como uma espécie de “escola de cidadania”, pois a pesquisa mostrou os diferentes aprendizados dos seus participantes, bem como o envolvimento dos mesmos em diversos Conselhos de Políticas Públicas, o que acabou favorecendo a integração entre eles. Para esse desenvolvimento, a pesquisa fez uso da metodologia qualitativa, utilizando, dentre outros instrumentos, a entrevista semiestruturada, a análise de documentos e a observação participante nas reuniões do OP. Esse estudo possibilita afirmar que essas experiências são importantes para a construção de uma “cidade educadora”, na qual aconteçam políticas públicas que despertem para valores como a igualdade e a solidariedade e estimulem o exercício da cidadania, despertando cada vez mais interesse em participar e se conceber como cidadão.

Palavras-chave: Gestão democrática, educação, cidadania, participação popular, orçamento participativo, política educacional. 


\begin{abstract}
Participatory democracy is being emphasized in the sphere of public administration. The most prominent experience, even international, is the Participative Budget, in which people deliberate about the priorities to be inserted in the public budget. Many studies have emphasized that these practices allow their participants to do an active citizenship exercise, developing more and more the spaces of popular participation that are peculiar in democratic societies - Freire, Benevides, Gohn, Pontual. We also admit that these experiences with Participative Budget are contributing to the development and integration in other participative practices. The present research aimed to study the instrument of democratic management called "Participative Budget", that was implemented by the Municipal Administration of Araraquara City Hall in São Paulo State, working with the hypothesis that this mechanism of popular participation contributes to the education to the citizenship of the participants in this process, encouraging them to be involved in other spaces of participation and social control. We could notice that this participation contributes, in fact, to the formation of citizens, with a kind of "school of citizenship", as the research showed different learning by their participants, as well their involvement in many Public Policy Councils, helping to integrate them. To this development, the research used qualitative methodology, making use of many different instruments as semistructured interview, analysis of documents and participative observation in the "Participative Budget" meetings. This study enabled us to say that these experiences are important to build an "educator city", in which public policy can happen to awake for values as equality and solidarity and to stimulate the practice of citizenship, in order to interest more and more the participation and the act of being citizen.
\end{abstract}

Key-words: Democratic management, education, citizenship, popular participation, participative budget, educational policy. 


\section{SUMÁRIO}

Introdução

CAPÍTULO 1

Estado e Democracia

- Cidadão e Cidadania: onde entra a Educação? 28

- O Processo Dialógico Despertando Consciências 32

- $\quad$ Educação Política para a Participação 38

CAPÍTULO 2

Participação Popular nas Administrações Públicas 41

- Alternativas da Participação Popular 44

- Conselhos 44

- Orçamento Participativo: Espaço de participação Política 45

- Experiências anteriores de Orçamento Participativo 48

CAPÍTULO 3

O Despertar para a Participação e Educação Cidadã no Município de Araraquara $\quad 56$

- A Gestão Educacional Democrática 58

- Gestão Democrática na Saúde e os Conselhos Gestores de Unidades 68

- A Experiência de Orçamento Participativo de Araraquara 69

CAPÍTULO 4

O que as Entrevistas Revelaram... 97

O PROCESSO EDUCATIVO E A PARTICIPAÇÃO POPULAR : 104 ALGUMAS CONSIDERAÇÕES

REFÊRENCIAS BIBLIOGRÁFICA 109

$\begin{array}{ll}\text { ANEXOS } & 114\end{array}$ 


\section{INTRODUÇÃO}

Temas como participação popular, democracia e cidadania fizeram parte da minha formação pessoal e me motivaram a escolher a graduação em Ciências Sociais e também a profissão de educadora (professora efetiva da rede estadual de São Paulo desde 1989). Minha prioridade e história de vida baseiam-se no compromisso de contribuir para a construção de um mundo mais justo e democrático, com mulheres e homens exercendo sua cidadania. Nesse sentido, destaco minha atuação na Pastoral da Juventude, movimento de cunho progressista da Igreja Católica, que desde os meus 15 anos de idade me fez perceber a importância da participação cidadã.

No entanto, a questão que despertou meu interesse para o aprofundamento do estudo e a realização do Curso de Mestrado foi a transformação ocorrida na política municipal da cidade de Araraquara/SP a partir do pleito eleitoral do ano 2000, no qual o Partido dos Trabalhadores (PT) venceu as eleições.

Esta cidade, por sua história, sempre apresentou um perfil político conservador (Kerbauy,2000). Refiro-me ao contexto geral de sua população, mesmo sabendo da existência de grupos que, embora reduzidos, sempre ofereceram resistência a essa tendência conservadora da cidade. Essas pessoas estavam engajadas principalmente no movimento estudantil, já que eram alunos da UNESP (a maioria vindos de outras cidades), que foram se envolvendo com a cidade e formando lideranças que culminaram na fundação do Partido dos Trabalhadores (PT), até a eleição de um Prefeito Municipal desta base social.

Com a eleição do PT, foram abertos espaços de participação na Administração Municipal que antes não existiam. A implementação do Orçamento Participativo, dos Conselhos de Escola e de Unidades Básicas de Saúde (UBS) mobilizou uma cidade sem histórico participativo. Os conselhos foram escolhidos por terem sido implementados nos bairros da cidade onde existiam escolas e UBS, abrindo assim a possibilidade de participação de um número maior de pessoas em espaços de descentralização do poder público.

Fui convidada, então, a integrar a equipe da Coordenadoria de Participação Popular no início desse governo (2001), onde ainda me encontro na condição de pesquisadora participante. Também é importante esclarecer que, apesar do grande envolvimento com a pesquisa, procuro manter o distanciamento necessário para as análises dos dados. Integrar a 
referida Equipe possibilitou-me perceber a mudança que ocorreu na cidade e também nas pessoas que participavam desses espaços, o que me motivou a estudar e escrever sobre o assunto que se tornou referência para Araraquara.

Em minhas observações sobre o Orçamento Participativo da cidade, pude perceber o envolvimento das pessoas com essa Administração Municipal e as mudanças ocorridas durante os quatro anos dessa Administração. Nesse sentido, o que me motiva neste trabalho é analisar o processo educativo das ações de participação popular e as mudanças de mentalidade, de comportamentos, de valores e de procedimentos, pois parto da hipótese de que o processo do Orçamento Participativo pode possibilitar importantes aprendizados para os seus participantes no que diz respeito à cidadania.

Sendo assim, a realização do presente trabalho tem o intuito de colaborar com as discussões realizadas sobre participação popular e a educação para a cidadania, a partir das quais

podemos promover entre os atores da sociedade civil uma apropriação dos mecanismos de funcionamento do estado e do instrumental necessário a uma melhor capacitação para que tais atores possam interferir na formulação, execução e gestão das políticas públicas. (Pontual, 2000, p.2)

O objeto desta pesquisa, portanto, é o processo educativo, visando ao exercício da cidadania dos participantes do Orçamento Participativo do município de Araraquara e como a inter-relação entre as diferentes formas de participação popular contribui, ou não, para a educação das pessoas, no que diz respeito à formação para a cidadania.

Para tanto, tomou-se como alvo da investigação, a implementação do processo de gestão democrática na cidade de Araraquara pela Administração "Democrática e Popular”, na Gestão de 2001-2004, isto é, os canais que possibilitaram a participação dos atores da sociedade civil, tendo como referência o "Orçamento Participativo”. 


\section{OBJETIVOS E HIPÓTESE}

O primeiro governo da Frente Democrática e Popular de Araraquara no interior do estado de São Paulo, que é composto pelos partidos PT, PSB e PC do B, implementou o que estava proposto em seu Plano de Governo em relação à gestão democrática e à participação popular (2001 a 2004). A prioridade do governo municipal desse período estava baseada na crença de que a administração pública deveria estar comprometida com a transformação social, buscando objetivos que atendessem aos interesses da classe trabalhadora. Esse governo sucedia administrações pautadas pelo autoritarismo e pela ausência de participação da sociedade.

Uma parcela da esquerda tendeu a erigir a democracia como valor estratégico, tornando-a uma referência básica nos níveis prático e teórico - donde a recorrência das idéias de direitos e cidadania. Como não poderia deixar de ser, estas circunstâncias condicionaram experiências e reflexões sobre a participação popular. (Daniel, 1994, p.22).

Esse Governo de Araraquara confirma a afirmação de Daniel, no sentido de que alguns gestores públicos são mais sensíveis às questões relacionadas à participação popular como um mecanismo de estímulo ao exercício da cidadania.

Foram criados na cidade, então, o Orçamento Participativo (OP), os Conselhos de Escolas Municipais, de Unidades de Saúde e foram ampliados os Conselhos Municipais setoriais, a partir da participação dos representantes das regiões do OP. Sendo assim, objetivou-se verificar o aprendizado desses participantes no que diz respeito à educação para a cidadania que o processo do OP pode, potencialmente, proporcionar, além de observar se houve uma ampliação dessa participação, isto é, se esses atores se engajaram em outros espaços de participação popular além do OP.

Em função dessa hipótese, algumas questões impõem-se como prioridade a este trabalho: O Orçamento Participativo colabora, de fato, com a formação para a cidadania? Ele dinamiza a participação popular? É um mecanismo que estimula a cidadania ativa ${ }^{1}$ ? A multiplicação de espaços de participação popular propicia a conscientização ${ }^{2}$ cidadã? O OP facilita essa multiplicação de espaços de participação? Como se relacionam os diversos

\footnotetext{
${ }^{1}$ Destacamos o conceito de cidadania ativa da autora Maria Victória Benevides, que define cidadão como aquele que busca abrir novos espaços de participação política.

2 Para o termo conscientização teremos como referência Paulo Freire nos livros "Educação como Prática para a Liberdade" e "Pedagogia do Oprimido", para quem o indivíduo consciente integra-se a sua realidade tendo a capacidade de transformá-la inserindo-se, assim, no processo histórico como sujeito.
} 
espaços de participação popular? Existe uma ligação e uma transversalidade entre eles que desemboquem na conscientização para a cidadania? A educação para a cidadania se dá pelos espaços de participação popular? Como?

Com este trabalho também se pretende refletir sobre a existência de uma relação interdisciplinar que um processo de participação popular pode desenvolver, isto é, analisar a proposta de participação popular de um governo democrático e popular que, pela primeira vez, chega ao poder em uma cidade considerada conservadora. É também necessário pensar em como essa relação entre Orçamento Participativo e Conselhos pode auxiliar na questão da formação cidadã, fazendo com que essa educação se torne "um serviço público, ou seja, transformá-la a partir do eixo central da res publica, e não dos interesses privados, patrimoniais, clientelistas ou meramente corporativos”. (Spósito, 1999, 46).

\section{METODOLOGIA}

O estudo será desenvolvido mediante análise da implementação do projeto de gestão democrática da administração municipal de Araraquara e o seu processo educativo. Para tanto, foi realizado um levantamento dos procedimentos político-administrativos deste governo e da relação existente com os mecanismos de participação popular, tendo como base o Orçamento Participativo. Para essa realização, o trabalho utilizou como fonte, as informações fornecidas pela Prefeitura Municipal.

A fim de atingir os objetivos pretendidos, este Projeto pressupõe a realização da pesquisa nos moldes de Lakatos \& Marconi (2001, p. 43), para quem a pesquisa “divide-se em pesquisa documental (ou fontes primárias) e pesquisa bibliográfica (ou de fontes secundárias)" - grifos das autoras - prevendo-se além do levantamento de estudos e documentos existentes, a consulta de dados estatísticos disponíveis.

Para verificar o processo de gestão democrática, nas suas diferentes manifestações adotou-se como método de trabalho, a metodologia qualitativa e como instrumentos de pesquisa, a observação e a entrevista. Levando em consideração que a pesquisadora se encontra na posição de ator-pesquisador, no qual é agente participante de pesquisa, foi utilizado como método a pesquisa-ação. Tendo sido tomados os cuidados acadêmicos necessários para que não houvesse a interferência entre os dois papéis: o de pesquisadora e o de participante do programa pesquisado. 
Essa modalidade de pesquisa, de abordagem metodológica qualitativa, amparada nos fundamentos da História Oral, em que os propósitos de descrição e reflexão se encontram na captação, registro e análise das informações coletadas. Esse procedimento foi escolhido porque melhor se adaptava ao tipo de informação necessária a situação particular da minha dupla atuação. Segundo Bogdan e Biklen (1994), isso nos permitirá “avaliar” de forma mais direta a reação dos entrevistados frente aos problemas colocados, bem como perceber de forma mais consistente suas opções, pois, obedecidas as cinco características principais da investigação qualitativa, os objetivos previstos nesta Pesquisa terão condições de ser alcançados, pois:

A fonte direta dos dados é o ambiente natural e o pesquisador, o instrumento principal, freqüentando o local em estudo e se familiarizando com ele, interessando-se pelo contexto e as relações com os sujeitos;

A investigação é descritiva, de modo que palavras, imagens, cenas, ambientes, episódios, situações, pensamentos e depoimentos são minuciosamente descritos;

Os pesquisadores se detém mais no processo que no resultado e nos produtos, buscando-se as causas, as origens, a história de comportamentos, ações e pensamentos expressos pelos sujeitos investigados, procurando compreender o que interfere nesses pensamentos e ações e como estes se traduzem em atividades e interações diárias;

A análise dos dados se processa de forma indutiva, ou seja, nem sempre os dados são obtidos para comprovar hipóteses construídas previamente, porem, muitas, emergem dos próprios dados;

O significado é de importância fundamental, pois ele se dá através do processo de busca de compreensão dos fenômenos que ocorrem em determinado contexto, instituição ou comunidade.( Bogdan e Biklen, 1994, p.43).

Com relação às entrevistas, essas tiveram um caráter semi-estruturado, elaborandose, previamente, um Roteiro de Orientação das mesmas, mas suficientemente flexível, de forma que possibilitasse acrescentar perguntas de esclarecimentos, tendo como base de atuação a flexibilidade.

Para tanto, escolheu-se uma amostra de pessoas a serem entrevistadas, dentre o conjunto de conselheiros eleitos nos anos de 2001 a 2004 no processo do OP, que envolvia cerca de 56 pessoas anualmente tendo sido escolhidas 22 pessoas considerados os seguintes critérios: sexo, escolaridade, pessoas de diferentes regiões da cidade, segmentos representativos e participação ativa no processo. Também foram feitas as observações nas reuniões do OP e, para que não fosse perdido o material observado, foi criado um "caderno de campo” para as observações de caráter informativo. 
Como a Pesquisa tem caráter qualitativo, foi levantado o máximo de dados referentes ao objeto e ao universo da mesma, pois somente assim, obter-se-á um conjunto de dados que possibilitem analisar, de forma consistente, as questões suscitadas por este projeto.

\section{DESCRIÇÃO BREVE SOBRE OS CAPÍTULOS}

No primeiro capítulo são expostas algumas concepções do pensamento clássico sobre o Estado que auxiliam a reflexão e orientam o trabalho de pesquisa. No decorrer desse, as questões que envolvem a democracia serão desenvolvidas com maior atenção, assim como um levantamento teórico sobre cidadania, direitos e de valores como a igualdade.

No segundo capítulo, discute-se a questão da descentralização do poder público, tendo o Orçamento Participativo (OP) como um mecanismo de descentralização da Gestão Pública, sendo um exemplo de participação popular. São apresentadas de forma abreviada as descrições de duas experiências de municípios que desenvolveram esse projeto: Porto Alegre (RS) e Santo André (SP) e que, em certo grau, foram referencia para o programa de Araraquara.

O terceiro capítulo apresenta do processo de Gestão democrática da cidade de Araraquara (SP), tendo como foco principal o OP.

No quarto capítulo são apresentados os dados da pesquisa acerca do processo educativo que possibilitou, ou não, o processo do OP de Araraquara. 


\section{CAPITULO 1 \\ ESTADO, CIDADANIA E DEMOCRACIA}

Consideramos fundamental para o desenvolvimento da pesquisa o conhecimento do pensamento de alguns autores clássicos dos quais destacamos John Locke, Jean-Jacques Rousseau, Karl Marx e Antonio Gramsci a respeito da noção de Estado, uma vez que esse conceito nos reporta às questões de democracia, direitos sociais e cidadania.

Na teoria clássica sobre o Estado, destacamos a visão de John Locke sobre a formação de um governo, enquanto um poder político que irá determinar as leis que salvaguardam a liberdade individual e o respeito à propriedade, mantendo a sua segurança e garantindo, assim, os direitos, que eram denominados de "naturais”. A esse poder cabia governar, protegendo a sociedade civil. Em conseqüência, o Estado se torna o protetor do homem contra o seu estado de natureza.

Para Locke, o estado de natureza é aquele em que a pessoa se afirma como sujeito de direito e da liberdade, bem como da igualdade. Apesar do estado de natureza ser estabelecido pela liberdade, Locke afirma que há a necessidade da constituição de um governo para sanar os conflitos, destacando também que o homem não nasceu para viver sozinho, determinando a sociedade como um local para a vivência humana. A partir desse momento, a sociedade política começa a existir entre os homens quando estes concordam em transferir seus poderes naturais para uma autoridade, que seja de escolha comum, e assim possa decidir sobre os problemas coletivos. Neste sentido, esse governo deverá proteger os direitos naturais dos homens, pois esses direitos (à vida e à propriedade) pertencem ao homem no seu estado de natureza.

Segundo Dewey, Locke "designa por propriedade tudo que está implícito em "vida, liberdades e possessões"; o indivíduo tem a propriedade de si mesmo, de sua vida e de suas atividades: a propriedade, nesse sentido amplo, é que cabe à sociedade proteger.” (1970, p.19).

Locke desenvolve a idéia de contrato social como sendo um pacto, no qual as pessoas dão o seu consentimento para que se preserve a vida e a propriedade (direitos naturais), e, assim, sejam protegidos pela lei e, sob essa medida, concordem com a formação da sociedade civil. "O início da sociedade política depende do consentimento dos indivíduos de se unir e compor uma sociedade; e que, quando estão assim associados, podem instituir a forma de governo que melhor lhes convier.” (Locke, 2006, p. 144). 
Locke valoriza a sociedade civil como algo que vai trazer a razão ao indivíduo, em busca de uma boa relação entre ele e a propriedade, promovendo a justiça.

Já para Jean-Jacques Rousseau, o homem é corrompido pela sociedade civil e pela propriedade. A sociedade civil torna-se a base da desigualdade social, pois no momento em que o homem se apropria da posse da terra, gera um mecanismo de exclusão e de diferenciação entre as pessoas. Neste sentido, o Estado se torna, para Rousseau, uma criação da classe dominante para manter seus privilégios e garantir o direito de propriedade. Com a propriedade privada, a igualdade não pode mais existir. Esta sociedade abre caminho para os proprietários preservarem a ordem e manterem a hegemonia, controlando e legitimando a divisão entre ricos e pobres, regularizando a desigualdade e se tornando a classe dominante.

Em sua obra Contrato Social, Rousseau afirma que a base da sociedade estava no interesse comum pela vida social, no consentimento unânime dos homens em renunciar às suas vontades particulares em favor de toda a comunidade. Assim, o Estado deveria estar a serviço dos interesses comuns, propiciando a igualdade entre todos.

Para Rousseau, a busca de uma sociedade que seja democrática está vinculada à realização da vontade geral que implica em um contrato social, sendo esse a base legítima para uma comunidade que deseja viver sob o princípio da liberdade. Nesse sentido, essa sociedade não obedece apenas ao desejo de um grupo social, mas à vontade geral. A concepção de Rousseau sobre o direito político é baseada no processo democrático, pois a soberania vem do povo. Para ele, a participação do indivíduo na sociedade é de fundamental importância para um estado justo.

Rousseau também afirma que a passagem do estado de natureza para o estado civil é determinada por uma mudança no homem. Essa mudança baseia-se pela sua conduta moral e, a partir desse momento, há a necessidade de pensar mais em suas atitudes. Sendo assim, o homem perde a sua liberdade natural e passa a ter a liberdade civil. É a partir desse estágio que se desenvolve a vontade geral. Para o autor, somente a vontade geral pode orientar um Estado para o bem comum. Rousseau (1997, p. 85) destaca ainda que “o que existe de comum nesses vários interesses forma o liame social e, se não houvesse um ponto em que todos os interesses concordassem, nenhuma sociedade poderia existir. Ora, somente com base nesse interesse comum é que a sociedade deve ser governada”.

Podemos destacar no pensamento de Rousseau que a vontade de todos difere da vontade geral. A primeira está vinculada aos interesses particulares e à soma de suas 
vontades. A segunda está voltada aos interesses coletivos, comuns e de direcionamento público. Em seu pensamento, a vontade particular tende a predileções e a vontade geral inclina-se para a igualdade.

\begin{abstract}
Se, quando o povo suficientemente informado delibera, não tivessem os cidadãos nenhuma comunicação entre si, do grande número de pequenas diferenças resultaria sempre a vontade geral e a deliberação seria sempre boa. Mas quando se estabelecem facções, associações parciais a expensas da grande, a vontade de cada uma dessas associações torna-se geral em relação a seus membros e particular em relação ao Estado: poder-se-á então dizer não haver mais tantos votantes quantos são os homens, mas somente tantos quantas são as associações. As diferenças tornam-se menos numerosas e dão um resultado menos geral. E, finalmente, quando uma dessas associações for tão grande que se sobreponha a todas as outras, não se terá mais como resultado uma soma das pequenas diferenças, mas uma diferença única - então, não há mais vontade geral, e a opinião que dela se assenhoreia não passa de uma opinião particular. (Rousseau, 1997, p. 92)
\end{abstract}

Dentro do pensamento clássico, importa enfatizar as teorias marxistas. Essas vêm demonstrar que o Estado surge das relações de produção. O que guia a sociedade é fruto das condições materiais e as relações econômicas, isto é, a sociedade civil. Para Marx (1988), é a sociedade que modela o Estado e não vice-versa. O que determina o Estado é o modo de produção dominante. Nessa concepção, o Estado não defenderia o bem comum, mas os interesses de um determinado grupo social que detivesse os meios de produção, sendo este a expressão política da dominação de uma classe sobre a outra.

Marx, diferentemente de Locke e Rousseau, que tinham no Estado o regulador de uma vontade geral, apresenta um Estado vinculado às relações de produção da sociedade capitalista, que é dividida em classes, em que uma delas sempre domina a outra. Segundo este pensador, o Estado representa os interesses da classe dominante, sendo um instrumento dessa dominação. Marx demonstrou que na sociedade capitalista, o Estado representa apenas esta classe e age conforme o interesse dela, reforçando as desigualdades sociais. Essas desigualdades são provocadas pelas relações de produção do sistema capitalista, as quais dividem os homens em proprietários e não proprietários dos meios de produção. E nesse sentido, as desigualdades são à base da formação das classes sociais.

Para Marx, na sociedade capitalista a classe dominante detém o poder econômico e também o poder político. Essa classe tem poder sobre o Estado, podendo manter o controle, a dominação e a manutenção da divisão da sociedade de classes, bem como a exploração dos trabalhadores. 
No pensamento de Marx está explícita a idéia da superação do Estado burguês e a idéia de que esse deveria garantir a ordem social. Para ele, era necessária uma nova concepção de sociedade e essa seria definida a partir da classe trabalhadora.

Marx (1988), em sua obra “O Capital”, demonstra a necessidade de um processo histórico para a sociedade chegar às condições materiais para essa transformação da sociedade. Nessa sociedade, não haveria mais diferenciação entre o homem e o produto de seu trabalho, o que alcançaria o fim da relação de exploração e dominação. O objetivo seria alcançar uma concepção de homem como sujeito social e histórico.

Gramsci tem como referencial o pensamento Marxista na concepção de Estado. Para esse autor, o Estado reproduz as relações de produção, impedindo que os trabalhadores, a classe dominada pela burguesia, pudessem desenvolver a consciência de classe. O Estado se torna o disseminador da hegemonia burguesa.

Gramsci afirma que a classe dominante impõe sua ideologia mantendo seu domínio na sociedade civil. Essa hegemonia faz com que os dominados aceitem a concepção de vida dos dominadores.

Para ele "Estado é todo o complexo de atividades práticas e teóricas com as quais a classe dirigente justifica e mantém não só o seu domínio, mas consegue obter o consentimento ativo dos governos”. (GRAMSCI, 1984, p. 87)

Coutinho (2000) demonstra em sua análise que, para Gramsci, a sociedade civil é o palco das lutas por transformação da sociedade, na qual se busca o consenso da maioria. Para isso, é necessário abrir espaços no seio do Estado, pois este se torna, agora, permeável à ação das forças em conflito. “O centro da luta está na 'guerra de posições', na conquista paulatina de espaços no interior da 'sociedade civil' e, por meio e a partir dela, no próprio seio do Estado.” (Coutinho, 2000, p. 39). O Estado capitalista agora ampliado, na concepção de Gramsci, passa a ser o local de reivindicações da sociedade, o campo da luta de classes.

Para Coutinho (2000), o Estado não pode mais estar a serviço e representar apenas uma classe social, ser um "comitê executivo da burguesia”, como denominou Marx. Ele deve estar aberto a outros segmentos sociais e seus interesses. Apesar de ainda representar a classe dominante, o Estado não pode satisfazer somente o interesse de uma classe. Nesse sentido, ele se torna um local de disputa na luta de classes ou frações de classes. 
É na relação que se estabelece entre o Estado e a Sociedade Civil que se tem o entendimento entre público e privado e onde serão verificados os conceitos de democracia e de cidadania.

Coutinho (2000) toma como referência a democracia como sendo sinônimo de soberania popular:

Podemos defini-la como a presença efetiva das condições sociais e institucionais que possibilitam ao conjunto dos cidadãos a participação ativa na formação do governo e, em conseqüência, no controle da vida social. (Coutinho, 2000, p. 50).

Coutinho ainda retoma o conceito de Marx sobre a alienação, na qual o indivíduo não se apropria de todos os bens sociais criados por ele e também destaca a construção coletiva do espaço público desenvolvida por Rousseau:

Segundo Marx, os indivíduos constroem coletivamente todos os bens sociais, toda a riqueza material e cultural e todas as instituições sociais e políticas, mas não são capazes - dada a divisão da sociedade em classes antagônicas - de se reapropriarem efetivamente desses bens por eles criados. A democracia pode ser sumariamente definida como a mais exitosa tentativa até hoje inventada de superar a alienação na esfera pública. Desde Rousseau, o mais radical representante do pensamento democrático no mundo moderno, a democracia é concebida como a construção coletiva do espaço público, como a plena participação consciente de todos na gestação e no controle da esfera política. É precisamente isso o que Rousseau entende por "soberania popular". (Coutinho, 2000, p. 50).

Tendo em vista essa concepção de democracia, Coutinho acredita que o que melhor expressa essa denominação de democracia é a idéia de cidadania. Para ele, cidadania é a capacidade dos indivíduos, ou do conjunto deles, de se apropriarem dos bens coletivos, que foram criados historicamente pelo conjunto da sociedade.

Segundo o mesmo autor, a cidadania está vinculada à idéia de direitos. Ele retoma a idéia de Locke, que baseou seu pensamento na questão das garantias dos direitos naturais pelo Estado, como vimos no início deste texto. Ele também destaca as contribuições do autor T. H. Marshall, que define a cidadania e o desenvolvimento dos direitos dentro do processo histórico.

Marshall (1957) divide o desenvolvimento da cidadania em 3 fases distintas da história: os direitos civis, os direitos políticos e os direitos sociais. Os direitos civis, criados no século XVIII, são aqueles baseados na liberdade, no direito à propriedade e à igualdade perante a lei. Já os direitos políticos, que ele determina como sendo do século XIX, eram 
constituídos do direito de participar no exercício do poder político. Mas esse direito não era estendido a todos, pois só participavam do poder político aqueles que eram detentores de propriedades. Não era, portanto, um direito estendido a todos, pois estava atrelado à questão econômica. Sendo assim, o direito político é visto como um direito secundário em relação aos direitos civis, que eram estendidos a todos os cidadãos na questão da liberdade e da igualdade. Somente no século XX, é que os direitos políticos atingem a cidadania com o direito do voto a todos os cidadãos. O direito social aparece no século XX como forma de diminuir a carência das camadas empobrecidas. Esse foi estabelecido num momento em que se desenvolvia o Estado de bem-estar social na Inglaterra e na Europa Ocidental. Os direitos sociais seriam aqueles em que estaria garantida uma qualidade de vida mínima. Esses englobam o direito ao trabalho e aos direitos do trabalhador, o direito à seguridade social e o direito à educação. O autor também divide esses direitos em períodos históricos, mas devemos ter o cuidado de examiná-los de maneira flexível, pois esses direitos (civis, políticos e sociais) se entrelaçam e se complementam.

É no século $\mathrm{XX}$ que os direitos que foram surgindo no decorrer da história se completam podendo, assim, ser identificados como direitos da cidadania (Fedozzi,1999). Apesar de serem considerados direitos da cidadania, ainda há dificuldades em se expandirem e se fazer apropriar desses direitos todas as camadas da população.

Para Benevides (1994), os direitos se tornaram concessões de uma classe para a outra, retirando do seu seio o significado de direito como algo conquistado e se tornando um favor, como poderemos ver também em Coutinho.

Nessa evolução - um avanço evidente no cenário do liberalismo manifesta-se também a contradição entre teoria e prática, na medida em que direitos passam a ser entendidos como concessões. Isto é, direitos são concedidos não como prestações legítimas para os cidadãos livres e iguais perante a lei, mas como benesses para os protegidos, tutelados, clientelas. Deixam de ser direitos para serem alternativas aos direitos. (Benevides,1994, p. 7).

Coutinho (2000) entende que os direitos sociais são conquistas da classe trabalhadora, bem como os direitos políticos, pois hoje o direito ao voto é universal. Os direitos de cidadania, assim como a democracia, vêm em decorrência da luta dos trabalhadores.

Para Benevides, cidadania não é só sinônimo de democracia, por isso ela passa a chamar de cidadania ativa aquela que representa a cidadania democrática no que diz respeito à soberania popular. 
Desta forma, as palavras cidadania e cidadão, referem-se, necessariamente, à participação na vida da cidade, entendida como o espaço público para as decisões coletivas. Nessa democracia antiga havia a clareza do termo cidadania, porque só se admitia como cidadão o membro ativo, que participava da vida pública. Aquele que não era ativo (o escravo, a mulher, o estrangeiro, por exemplo), simplesmente não era considerado cidadão.(Benevides, 1994, p. 13).

Neste sentido, a participação popular se torna o fundamento e a base da cidadania ativa. Para que isso aconteça, é necessária a criação de espaços públicos para que a soberania popular não esteja restrita apenas ao processo eleitoral, mas que tenha a possibilidade de "criação, transformação e controle sobre o poder, ou os poderes." (Benevides, 2003, p. 20).

Segundo Bobbio (2000), a regra da democracia é a maioria tomando decisões coletivas. Para essa decisão, é primordial que sejam garantidos os direitos de reunião e de associação. Esses direitos são as bases do Estado liberal. Para o autor, só um Estado democrático é capaz de garantir essas liberdades fundamentais. A relação entre o Estado liberal e o Estado democrático é a concessão dos direitos políticos como algo intrínseco aos direitos de liberdade, pois somente com o controle do poder haverá a garantia dos direitos da liberdade.

Para ele, a democracia e o exercício da cidadania não se dão somente pelo voto em representantes tanto para o Legislativo como para o Executivo, mas defende que o mais importante é termos uma quantidade de espaços, nos quais o cidadão poderá decidir.

Hoje, se se quer apontar um índice do desenvolvimento democrático este não pode mais ser o número de pessoas que têm o direito de votar, mas o número de instâncias (diversas daquelas políticas) nas quais se exerce o direito de voto; sintética mas eficazmente: para dar um juízo sobre o estado da democratização num dado país o critério não deve mais ser o de" quem" vota, mas o do "onde" se vota ( e fique claro que aqui entendo o "votar" como ato típico e mais comum do participar, mas não pretendo de forma alguma limitar a participação ao voto).” (Bobbio, 2000, p. 68)

... Deveremos procurar ver se aumentou não o número de eleitores mas o espaço no qual o cidadão pode exercer seu próprio poder de eleitor.(Bobbio, 2000, p. 69).

O autor levanta uma questão pertinente no momento de fortalecimento da democracia, na medida em que o sujeito social, o cidadão ativo, não pode se limitar a exercer sua cidadania na época das eleições de seus representantes, sejam municipais, 
estaduais ou nacionais. A cidadania se constrói no processo democrático, no qual o cidadão participa dos espaços de debate e de decisões existentes.

Ghon aponta a soberania popular como um princípio da democracia, argumentando que

a participação popular é concebida como um fenômeno que se desenvolve tanto na sociedade civil - em especial entre os movimentos sociais e as organizações autônomas da sociedade; quanto no plano institucional - nas instituições formais políticas. (2001, p. 17).

A participação das pessoas que se mobilizam para garantir seus direitos sociais nos remete para a valorização dos direitos políticos, pois os dois estão ligados, uma vez que o fortalecimento dos direitos políticos organiza as pessoas para a conquista dos direitos sociais, estabelecendo a cidadania ativa. (Benevides,1994).

Cidadania ativa é aquela que institui o cidadão como portador de direitos e deveres, mas, essencialmente, criador de direitos para abrir novos espaços de participação política. (Benevides, 1994, p.16).

Sendo assim, Benevides (2003), Ghon (2001) e Bobbio (2000) destacam que a participação cidadã e a soberania popular são princípios fundamentais e que devem ser estimulados diversos mecanismos para essa participação. Podemos destacar, na obra de Benevides, mecanismos como o plebiscito, o referendo, os projetos de iniciativa popular e os conselhos.

Com relação às questões sobre democracia e cidadania, há um pressuposto que se faz necessário, que é a criação de um sentimento de identidade, no qual os indivíduos se sintam cidadãos. Para tanto, Telles (1994) analisa que a ausência de espaços públicos, que proporcionem essa identidade social e também a negação dos direitos, pode prejudicar o convívio coletivo:

A ausência de espaços de reconhecimento e de vínculos propriamente civis, traduz-se nas dificuldades de formular os dramas cotidianos (individuais e coletivos) na linguagem pública dos direitos, tendendo, por isso mesmo, a ser equacionados no interior dos códigos morais da vida privada. É nisso que a negação dos direitos, o não reconhecimento dos outros como sujeitos de interesses e aspirações legítimas, afeta sociabilidade, cultura e identidade (Telles, 1994, p. 45).

A redução dos espaços públicos faz com que o sujeito social fique submetido às questões impostas pelo mercado, gerando a exclusão e a não identidade social na medida em que gera cada vez mais desigualdades e injustiças, negando, assim, “a dimensão ética 
da vida social através da recusa de um sentido de responsabilidade pública e de obrigação social.” (Telles, 1994, p. 45).

Destacamos nossa identidade com a autora ao defender que, para a realização da democracia, são necessários o fim dos privilégios e a disseminação de um pensamento que proporcione a cultura da igualdade, reconhecendo que todos os indivíduos são sujeitos de direitos.

Longe de corresponder a um processo harmonioso e linear, esta é uma construção a cada momento feita e refeita no terreno conflituoso e sempre problemático da vida social. Mas sinaliza um campo no qual a utopia democrática pode ser formulada na aposta de que homens e mulheres descubram o sentido do espaço público no qual as diferenças se expressam e se representam numa interlocução possível; no qual valores circulam, argumentos se articulam e as opiniões se formam; no qual parâmetros públicos podem ser construídos e reconstruídos como balizas para o debate em torno de questões pertinentes; e no qual, enfim, a dimensão ética da vida social pode se constituir através da convivência democrática com as diferenças e os conflitos que elas carregam, exigindo por isso mesmo, de cada um, a cada momento, o exercício desta capacidade propriamente moral de discernimento entre o justo e o injusto. Esta medida, por ser desprovida de garantias e pontos fixos, ainda mais nesse final de século que fez desmoronar antigas certezas, só pode ser construída numa permanente e sempre renovada negociação (Telles, 1994, p. 48).

A igualdade é questão fundamental em uma democracia, como bem expressa o artigo $1^{\circ}$ da Declaração Universal dos Direitos do Homem, de 1948, ao afirmar que "todos os homens nascem livres e iguais em dignidade e direitos”. Essa afirmação nos faz refletir até que ponto a questão da igualdade é tida como algo inerente à pessoa e se é respeitada como um valor, no que diz respeito a sermos iguais perante uma coletividade e termos os mesmos direitos nos acessos básicos à vida de cada ser humano.

Lafer (1988), por outro lado questiona o fato de a igualdade ser uma convenção e não um dado natural, uma vez que é a sociedade que decide o que ela significa, garantindo, só nessa condição, os direitos de sermos iguais:

Nós não nascemos iguais: nós nos tornamos iguais como membros de uma coletividade em virtude de uma decisão conjunta que garante a todos direitos iguais. A igualdade não é um dado [...] Ela é construída, elaborada convencionalmente pela ação conjunta dos homens através da organização da comunidade política. Daí a indissolubilidade da relação entre o direito individual do cidadão de autodeterminar-se politicamente, em conjunto com seus concidadãos, através do exercício de seus direitos políticos, e o direito da comunidade de autodeterminar-se, construindo convencionalmente a igualdade (Lafer, 1988, p. 150). 
A igualdade torna-se um valor ético retratado pela sociedade principalmente a partir da Revolução Francesa. Ao longo da História pudemos verificar que a questão da desigualdade era uma relação natural. Muitos eram considerados inferiores e alguns nem eram considerados pessoas, como podemos lembrar de tantas situações, nas quais o ser humano foi violentado e tratado de forma discriminatória e até mesmo cruel, sejam em regimes ditatoriais, escravocratas ou em situações de guerras. Foi na construção de uma consciência coletiva que se consolidou o direito de que todos nascemos iguais.

Uma sociedade democrática faz da igualdade uma questão fundamental, que deve ser entendida fora da questão da uniformidade, isto é, temos as nossas diferenças específicas de seres humanos, mas somos iguais em dignidade e direitos. Por isso, Lafer (1988) ressalta o pensamento de Hannah Arendt sobre a necessidade de separar a esfera pública da esfera privada:

Na esfera do público, que diz respeito ao mundo que compartilhamos com os outros e que, portanto, não é propriedade privada de indivíduos e/ou do poder estatal, deve prevalecer, para se alcançar a democracia, o princípio da igualdade. Este não é dado, pois as pessoas não nascem iguais e não são iguais nas suas vidas. A igualdade resulta da organização humana. Ela é um meio de se igualizar as diferenças através das instituições. É o caso da polis, que torna os homens iguais perante a lei. Por isso, perder o acesso à esfera do público significa perder o acesso à igualdade. Aquele que se vê destituído da cidadania, ao ver-se limitado à esfera do privado fica privado de direitos, pois estes só existem em função da pluralidade dos homens, ou seja, da garantia tácita de que os membros de uma comunidade dão-se uns aos outros. É neste sentido preciso que para Hannah Arendt a política institui a pluralidade humana e um mundo comum. (Lafer, 1988, p. 152)

A igualdade como um direito humano deve ter como fator primordial para sua realização a cidadania. É ela que vai garantir que se estabeleça uma relação de proteção, fazendo com que se torne um valor universal no âmbito da sociedade. A cidadania dará o valor real da existência desse direito, fazendo com que a esfera pública se diferencie da esfera privada, tornando assim a igualdade um princípio na esfera pública.

Para essa mudança de valores, a sociedade deve estabelecer os direitos como algo fundamental para a democracia e o exercício da cidadania ativa se torna indispensável para alcançar essa finalidade. Nesse sentido, podemos destacar a organização dos movimentos sociais, que têm como característica descentralizar os espaços públicos visando a reivindicação dos direitos de uma coletividade. Para Telles (1994), os movimentos sociais tornam-se objeto principal na redefinição das relações entre Estado e sociedade. 
Chauí (1990), em sua análise, relata que os movimentos sociais têm dois pólos. Em um deles, os movimentos sociais se dirigem ao Estado, utilizando a pressão para reivindicar seus direitos sociais. O outro, é absorvido pela esfera estatal. Esses movimentos também têm a função de criar novos sujeitos sociais e de expressar as idéias de igualdade e justiça. Sendo assim, a democracia se torna local de conflitos, pois ela passa a ter como característica, a criação de direitos novos em função das condições históricas e das lutas sociais, por força das classes populares que são as protagonistas nos movimentos sociais em conflito com um Estado que favorece a classe dominante.

Chauí (1990) destaca ainda, três aspectos no debate sobre cidadania no Brasil. O primeiro, sobre a questão legal, que diz respeito à participação do cidadão por meio de eleições e dos partidos políticos, sendo a cidadania uma referência ao "direito de representação política”. O segundo, está vinculado ao Estado de Direitos, destacando os aspectos legais, no qual a cidadania está atribuída à tese dos direitos e das liberdades civis. O terceiro, refere-se às lutas das classes populares, por intermédio dos movimentos sociais, para abrir espaço e garantir a participação nas decisões sobre as suas condições de vida e de trabalho.

\footnotetext{
Quando se examina o largo espectro de lutas populares nos últimos anos pode-se observar que a novidade dessas lutas se localiza em dois planos principais: a) no plano político, a luta não é pela tomada do poder, mas pelo direito de se organizar politicamente e pelo direito de participar das decisões, rompendo a verticalidade do poder autoritário; b) no plano social, mais amplo, nota-se que as lutas não se concentram na defesa de certos direitos ou em sua conservação, mas na luta para conquistar o próprio direito à cidadania, pelo reconhecimento de novos direitos e, portanto, de novos sujeitos sociais. (Chauí, 1990, p. 297).
}

A autora enfatiza, portanto, a importância dos espaços de participação política para que se estabeleça a divisão do poder e o princípio da igualdade no processo democrático. Para tanto, pode-se apontar a necessidade da descentralização das discussões sobre políticas públicas, com ampla participação popular, propiciando uma das possibilidades de ampliação da democracia e o exercício da cidadania ativa.

Feitas essas ponderações, pode-se afirmar que foi estabelecido um diálogo com os autores que discutem o tema cidadania, participação popular e o seu processo educativo, destacando um mecanismo de participação popular que surge no final do século XX, alternativa esta que coloca nas mãos da população, a tomada de decisão sobre o orçamento voltado para o investimento público: o Orçamento Participativo. 


\section{CIDADÃO E CIDADANIA: ONDE ENTRA A EDUCAÇÃO?}

O presente trabalho inicia esse questionamento com uma das afirmações a que muitos regimes autoritários se apegavam para retardar o processo de participação da população nas decisões coletivas. O argumento utilizado era o de que havia a necessidade de se educar primeiro o indivíduo, para que, depois, ele pudesse exercer sua cidadania.

Nesse sentido, Arroyo destaca a tese da imaturidade do povo como algo que perpassa a história e justifica a instalação de regimes autoritários, tornando o povo excluído das decisões políticas:

A tese da imaturidade e do despreparo das camadas populares para a participação e para a cidadania é uma constante na história do pensamento e da prática política... Tanto nos longos períodos de exclusão do povo da participação, como nos curtos de abertura, o exercício da cidadania não é permitido porque o povo não está preparado. O que diferencia, neste particular, as elites autoritárias das liberais é que estas se declaram a favor de educar as camadas populares para, um dia, participarem: o dia em que essas elites as julguem capacitadas. (Arroyo,2003, p. 33).

Esse discurso de educar primeiro o povo para depois lhes dar o poder da decisão e da participação acaba se tornando um mecanismo de controle utilizado pelas camadas dominantes, tendo como objetivo a submissão do povo nesse processo.

Essa idéia de que a educação para a cidadania fazia-se necessária anteriormente à sua participação vem ao encontro do pensamento atual, como podemos observar no estudo de Arroyo:

O pensamento político-educativo do século XVII não parece estar tão distante do pensamento e do comportamento político adotado três séculos depois por governos liberais e por progressistas e democratas para com os "irracionais e desordeiros" assalariados. Ainda se justifica a tutela do Estado e a exclusão da cidadania, em nome da minoridade moral e da irracionalidade política dos assalariados. A liberaldemocracia continua condicionando o direito dos trabalhadores a serem membros do corpo político a que mostrem ter aprendido "o padrão moral exigido a um ser racional. (Arroyo, 2003, p. 46)

O vínculo estabelecido entre educação e cidadania como sendo uma condição para a participação política age, segundo Arroyo, como justificativa para a exclusão da cidadania:

Sem dúvida que os educadores e a pedagogia não criam essas justificativas, porém, quando se continua defendendo a vinculação tão 
mecânica entre educação, cidadania e participação, continua se reforçando aquela lógica mais global em que ambos nasceram vinculados. Passar por alto dessa lógica global e dos efeitos reais que ela legitimou e continuar defendendo a educação como o ritual sagrado de passagem para o reino da liberdade é uma forma de contribuir para que a cidadania continue a ser negada, reprimida e protelada. (Arroyo, 2003, p. 40).

Arroyo continua seu pensamento, destacando o fato de a educação se tornar prérequisito para a cidadania diminuir ou alongar o período de participação dos trabalhadores no âmbito político, no qual não estariam preparados para defender os interesses da burguesia:

Diríamos que exatamente por serem de fato o supremo manancial da riqueza da nação é que não podiam ser aceitos como capazes de ação política. Como nos lembra Marx, o mesmo mecanismo através do qual se dá a formação da riqueza, a acumulação do capital, produz, ao mesmo tempo, necessariamente, o seu contrário, a acumulação da miséria e o pauperismo de um excessivo exército de reserva: saem daí as "Classes perigosas", temidas pela sua irracionalidade política. Os trabalhadores não foram considerados apenas como pobres, objeto de caridade, nem como ignorantes, objeto de educação, mas foram considerados como classes perigosas, objeto de temor, de caridade, filantropia e educação, o que mostra que a submissão das camadas inferiores não era um fato, mas uma forma de propaganda ideológica da minoria dirigente civilizada. (Arroyo, 2003, p. 47).

Ele continua sua reflexão respondendo a uma questão pertinente no sentido de que os trabalhadores são excluídos do processo de decisão política, alegando que esse está ligado ao processo educativo:

Como manter esse manancial de riqueza tão explosivo? Condenando suas ações políticas como irracionais, mantendo-os excluídos do poder, das decisões e da política. Não é uma questão pedagógica, mas uma questão política, uma expressão do confronto entre as duas classes em formação. Reduzir a questão da cidadania dos trabalhadores a uma questão educativa é uma forma de ocultar a questão de base. É o que vem se tentando fazer nos últimos séculos, quando se coloca a educação como pré condição para a cidadania. (Arroyo, 2003, p. 47).

A idéia de primeiro educar para a cidadania vem atrelada a interesses de protelar essa participação e desenvolvimento político das camadas trabalhadoras, pois segundo Bobbio “a educação para a democracia surgiria no próprio exercício da prática democrática” (2000, p. 43). Assim, a participação em espaços políticos faz com que o indivíduo se eduque para a participação e não necessariamente o contrário. Estando em um ambiente político de discussão, de reflexão, num ambiente dialógico, o cidadão aprende, 
mas também ensina por meio de sua vivência e vai se educando através da interagindo com outros cidadãos e com sua cidade.

Sendo assim, o argumento que está estabelecido não caracteriza uma forma plausível de educação para a cidadania, pois a possibilidade de esperar que, em especial, a escola realize esse papel significa que serão necessários muitos anos, como já temos percebido e não imediatamente. A escola tem seu papel nessa realização, pois cabe a ela, também, educar a criança e o jovem para a democracia, sendo esta também democrática. Mas o processo pedagógico que estamos discutindo aqui diz respeito ao envolvimento das camadas trabalhadoras no processo de participação política e, assim, na vivência deste, e a partir dele, estabelecer-se um aprendizado no que diz respeito à cidadania.

Essa relação entre educação e cidadania, segundo Arroyo, existe "no sentido de que a luta pela cidadania, pelo legítimo, pelos direitos, é o espaço pedagógico onde se dá o verdadeiro processo de formação e constituição do cidadão.” (2003, p. 79). Ou seja, a participação política deve se tornar uma condição na vivência do povo e, insistindo-se nisso, o exercício da cidadania criará uma cultura de participação.

Num Estado democrático estabelecido constitucionalmente é prevista a permanência do Estado de Direitos, no qual os indivíduos são iguais e têm o exercício do poder regulamentado pelas leis. Esse Estado pode garantir direitos, mas isso não significa que esse indivíduo se torne um cidadão ativo. Ele pode apenas receber esses direitos de forma passiva, continuando por longo tempo, governado e tutelado.

Na concepção clássica, observa-se a vinculação da cidadania à noção de direitos à liberdade dos cidadãos (ainda que restrita a poucos, aos proprietários) era dirigida pela razão, utilizando o pensamento, a lógica e o cálculo utilitário. A cidadania do século XIX, ao contrário dos séculos anteriores, se dirige a todos, inclui as massas, mas para disciplina-las e domesticá-las. Espera-se que os membros do tecido social, através da educação, participem do convívio social de forma harmoniosa. Os direitos sociais não são conquistados. São outorgados pelo Estado. Neste processo, onde a educação tem destaque, a prática pedagógica enfatiza as estratégias de persuasão, esclarecimento e moralização de cada futuro cidadão. (Gohn, 1994, p. 14).

Gohn destaca, também, a influência do Estado na vinculação dos direitos, sendo ele o facilitador na obtenção desses, inviabilizando o processo de organização da população para o exercício reivindicatório e cidadão deste processo.

O século XX trará novas acepções ao conceito de cidadania. O projeto burguês enfatizará a questão dos direitos dos indivíduos, menos como direitos e mais como deveres. Deveres para com o Estado, o interlocutor oficial da sociedade. O Estado passa a regulamentar os direitos dos 
cidadãos e a restringi-los, ou cassá-los, em determinadas conjunturas históricas. A questão da cidadania deixa de ser conquista da sociedade civil e passa a ser competência do Estado. (Gohn, 1994, p. 14).

Um outro autor, (Canivez,1991), ressalta o pensamento de Aristóteles, para quem o conceito de cidadão autêntico é definido como aquele que participa de assembléias do povo e que se envolve de maneira ativa na vida da cidade, isto é, governa junto com o Estado.

É diante deste aspecto que se mostra a educação para a cidadania. Canivez diz:

Essa educação não pode mais simplesmente consistir numa informação ou instrução que permita ao indivíduo, enquanto governado, ter conhecimento de seus direitos e de seus deveres, para a eles conformarse com escrúpulo e inteligência. Deve fornecer-lhes, além dessa informação, uma educação que corresponda à sua posição de governante potencial. (Canivez, 1991, p. 31).

A educação legitima e determina formas de vida política fazendo com que valores sejam propagados como objetivos dessa aprendizagem. Em geral, os valores priorizados são: a igualdade, o respeito aos direitos humanos, a solidariedade e o respeito a vontade da maioria, sem desrespeitar o direito das minorias.

Segundo Benevides, a educação para a democracia comporta duas dimensões:

A formação para os valores republicanos e democráticos e a formação para a tomada de decisões políticas em todos os níveis, pois numa sociedade verdadeiramente democrática ninguém nasce governante ou governado, mas pode vir a ser, alternativamente -- e mais de uma vez no curso da vida -- um ou outro. (Benevides,1996, p. 226)

A autora continua refletindo sobre a questão da educação para a democracia, destacando a importância de se despertar valores nos indivíduos:

Em sua primeira dimensão, a Educação para a Democracia consiste na formação do cidadão para viver os grandes valores republicanos e democráticos - de certo modo identificados com a tríade da Revolução Francesa e com as gerações de direitos humanos (do século 18 ao século 20), que englobam as liberdades civis, os direitos sociais e os de solidariedade dita "planetária". A educação como formação e consolidação de tais valores torna o ser humano ao mesmo tempo mais consciente de sua dignidade e da de seus semelhantes -- o que garante 0 valor da solidariedade -- assim como mais apto para exercer a sua soberania enquanto cidadão. Trata-se, pois, de uma curiosa inversão política, como se fosse um paradoxo: nas democracias a educação pública pode ser um processo iniciado pelo Estado, mas ela visa a fortalecer o povo perante o Estado, e não o contrário. (Benevides, 1996, p. 228). 
Ainda de acordo com a autora, a educação para a democracia tem como base a cidadania ativa, estabelecendo a relação entre a participação e os valores como liberdade, igualdade e solidariedade.

Ao discutir os valores democráticos é importante, no entanto, estabelecer certas prioridades e destacar o valor da solidariedade. A liberdade e a igualdade estão, como se vê, estreitamente ligada à tolerância. Mas esta é uma virtude passiva, ou seja, é a aceitação da alteridade e das diferenças, mesmo que seja uma aceitação crítica. Enquanto que a solidariedade é, em si mesma, uma virtude ativa - por isso muito mais difícil de ser cultivada -, pois exige uma ação positiva para o enfrentamento das diferenças injustas entre os cidadãos. A educação para esses três valores deve ser diferenciada. Não basta educar para a tolerância e para a liberdade, sem o forte vinculo estabelecido entre igualdade e solidariedade. Esta implicará no despertar dos sentimentos de indignação e revolta contra a injustiça e, como proposta pedagógica, deverá impulsionar a criatividade das iniciativas tendentes a suprimi-la, bem como levar ao aprendizado da tomada de decisões em função de prioridades sociais. (Benevides, 1996, p. 234).

Nesse sentido, a educação para a cidadania não pode ser apenas uma transmissora de informação, na qual o indivíduo tenha o conhecimento de seus direitos e deveres. Ela deve levar em conta espaços de vivência dos procedimentos de igualdade e solidariedade, tendo em vista o exercício reivindicatório e de reflexão dialógica sobre as demandas necessárias para a melhora nas condições de vida na cidade.

\section{O PROCESSO DIALÓGICO DESPERTANDO CONSCIÊNCIAS}

Um dos pensadores considerados referência nacional e internacional sobre este tema é Paulo Freire, razão por que esse autor será a base de nossa reflexão sobre o processo dialógico.

Para Freire, esse processo de educação acontecerá na medida em que as práticas forem baseadas no diálogo e na participação dos indivíduos enquanto sujeitos políticos, posicionando-se o autor contra toda submissão e passividade, propondo que essas práticas estejam voltadas para a tomada de decisões.

Sendo assim, a educação nas cidades se dará enquanto prática social e, assim, todos os ambientes participativos serão, em potencial, palco de educação e desenvolvimento para a cidadania: 
Relações entre educação, enquanto processo permanente e a vida das cidades, enquanto contexto que não apenas acolhem a prática educativa, como prática social, mas também se constituem, através de suas múltiplas atividades, em contextos educativos em si mesmas. (Freire, 2003, p. 16).

Para Freire, essa prática educativa faz com que as pessoas possam fazer a leitura do mundo de forma crítica, tendo a possibilidade de enxergar e refletir sobre o que é verdadeiro e não ver somente aquilo que interessa às classes dominantes.

Nesse sentido, destacamos a reflexão de Lima, ao se reportar a Freire, sobre a questão da participação:

A participação de que fala é uma participação no processo de decisão, um ato de "ingerência", e não a atitude de espectador que se limita a assistir ou, de mais ou menos longe, a contemplar. (Lima, 2000, p. 33).

O pensador, continuando sua argumentação na defesa do conceito Paulofeireano sobre a importância da participação para educar para a democracia, afirma:

Ao propor uma aprendizagem da democracia através do seu exercício e da sua própria existência, "aprendendo democracia prática da participação”, rejeita as teorias elitistas da democracia e opõe-se a perspectivas formalistas e instrumentais, subordinadas à "liderança competitiva", à "organização oligárquica" e à "racionalidade burocrática”. (Lima , 2000, p. 33).

Esse processo de aprendizagem democrática tem como característica o despertar da consciência para a verdadeira participação, aquela que possa gerar uma organização dos sujeitos, na qual tomem decisões, e que realmente gere uma redistribuição de poder. Freire nos mostra, então, como essa educação torna-se permanente:

A educação é permanente na razão, de um lado, da finitude do ser humano, de outro, da consciência que ele tem de sua finitude. Mais ainda, pelo fato de, ao longo da história, ter incorporado à sua natureza "não apenas saber que vivia, mas saber que sabia e, assim, saber que podia saber mais”. A educação e a formação permanente se fundam aí crítica. (Freire, 2003, p. 20).

Partindo dessa reflexão, observa-se que os processos de participação popular vêm gerando atores políticos que vão se enxergando como alguém que pode reivindicar, tomar decisões e emitir opiniões. É inserido dos movimentos sociais, associações de moradores, sindicatos, bem como em mecanismos de gestão democrática como os conselhos e também no Orçamento Participativo, que ele aprende e se desenvolve enquanto pessoa humana e um cidadão ativo. Nesse sentido, a educação é tida também como um processo de conhecimento, sendo formada na prática educativa do cotidiano. 
Diante dessa prática educativa do cotidiano, deve-se destacar que esse ensinamento não se dá pela transmissão passiva de conhecimentos, em que há uma pessoa que transmite e outra que recebe as informações. Essa educação acontece por intermédio da sua própria construção, onde o sujeito, participando, elabora suas experiências educativas de forma criativa, baseado na sua realidade, fazendo com que esse conhecimento gere nele atitudes participantes, de decisões e envolvimento com a realidade que lhe é apresentada, podendo, assim, interferir e transformar a sociedade e a si mesmo.

Para Freire, é importante que se respeitem os saberes das pessoas com as quais se quer fazer um diálogo educativo. Para ele, ensinar é aproveitar a experiência vivida pelos alunos em suas regiões, como por exemplo, a discussão sobre a poluição dos rios e os lixões em áreas das cidades. Essas discussões trazem para este sujeito a leitura de seu mundo e assim o subsidia para que ele possa modificar sua realidade, fazendo com que exista um caráter formador nessa mobilização estabelecida (Freire, 1996).

Freire também destaca a prática da solidariedade como característica importante no processo democrático:

A solidariedade social e política de que precisamos para construir a sociedade menos feia e menos arestosa, em que podemos ser mais nós mesmos, tem na formação democrática uma prática de real importância. A aprendizagem da assunção do sujeito é incompatível com o treinamento pragmático ou com o elitismo autoritário dos que se pensam donos da verdade e do saber articulado. (Freire, 1996, p. 47).

Os seres humanos são capazes de pensar o mundo a partir da consciência de sua existência, sendo aquele que aprende e transforma.

Quer dizer, já não foi possível existir sem assumir o direito e o dever de optar, de decidir, de lutar, de fazer política. E tudo isso nos traz de novo à imperiosa prática formadora, de natureza eminentemente ética. E tudo isso nos traz de novo a radicalidade da esperança. Sei que as coisas podem até piorar, mas também que é possível intervir para melhorá-las. (Freire, 1996, p. 58).

Essa interferência nas condições de vida do mundo é base fundamental para a educação para a cidadania, tendo como princípio básico o exercício desta para que se aprenda a realizar mudanças em prol dos menos favorecidos, inviabilizando, assim, a prática clientelista tão enraizada no nosso cotidiano. Nesse sentido, temos o homem e a mulher como sujeitos que fazem a História e, por isso, tornam-se "seres da decisão, da ruptura, da opção”. (Freire, 1996: 145). 
A partir dessas relações com a realidade, com sua integração, o desenvolvimento na sua capacidade de decisão e sua ação, interagindo como sujeito que interfere e transforma a sua realidade, podendo, assim, ser um agente ativo, podemos começar a definir esse sujeito como um ser consciente ou que esteja despertando para a conscientização. Esse indivíduo, segundo Freire,

Já não se satisfaz em assistir. Quer participar. A sua participação, que implica numa tomada de consciência apenas e não ainda uma conscientização - desenvolvimento da tomada de consciência - ameaça as elites detentoras de privilégios. (Freire, 1967, p. 63).

Para atingir a conscientização, é necessário que haja um ambiente social que propicie as discussões, análises críticas e o conhecimento da realidade, tornando o indivíduo responsável por seu ambiente e por suas decisões, comprometendo-se, assim, com a comunidade em que está inserido. Temos, então, a ação social gerando a conscientização e, para que isso aconteça, essa ação deve estar vinculada a uma reflexão. Sendo assim, ação e reflexão sobre essa prática, que é social, formam o processo de conscientização. As decisões devem ser tomadas junto com o povo e nunca para ou sobre o povo. Freire nos fala sobre o oposto desta situação, que é o que ainda temos, isto é, a base de servir o povo por intermédio do assistencialismo:

No assistencialismo não há responsabilidade. Não há decisão. Só há gestos que revelam passividade e "domesticação" do homem. Gestos e atitudes. É esta falta de oportunidade para a decisão e para a responsabilidade participante do homem, característica do assistencialismo, que leva suas soluções a contradizer a vocação da pessoa em ser sujeito, e a democratização fundamental, instalada na transição brasileira, a que já nos referimos. (Freire, 1967, p. 66).

No processo de conscientização, o sujeito sente-se co-responsável com a sua comunidade e não mero espectador da vida. Ele se sente parte integrante, pois pode decidir sobre a sua vida e a de sua comunidade.

Sendo assim, a educação, segundo Freire, deve ser o facilitador da reflexão, proporcionando para o indivíduo o desenvolvimento da capacidade deste poder de decisão:

É preciso, na verdade, não confundirmos certas posições, certas atitudes, certos gestos que se processam, em virtude da promoção econômica posições, gestos, atitudes que se chamam tomada de consciência - com uma posição crítica. A criticidade para nós implica na apropriação crescente pelo homem de sua posição no contexto. Implica na sua inserção, na sua integração, na representação objetiva da realidade. Daí a conscientização ser o desenvolvimento da tomada de consciência. Não será, por isso mesmo, algo apenas resultante das modificações econômicas, por grandes e importantes que sejam. A criticidade, como a entendemos, 
há de resultar de trabalho pedagógico crítico, apoiado em condições históricas propícias. (Freire, 1967, p. 69).

Para que essa consciência possa ser desenvolvida, há a necessidade de se estabelecer o diálogo, já que numa relação em que não haja diálogo existe o paternalismo, no qual um (o mais forte) concede benefícios a outros, estabelecendo uma relação de aceitação e não de decisão dialógica. “A dialogação implica na responsabilidade social e política do homem. Implica num mínimo de consciência transitiva, que não se desenvolve nas condições oferecidas pelo grande domínio.” (Freire, 1967, p. 78).

Pela história brasileira, dentro do processo de colonização, verifica-se que não foi proporcionada uma participação na resolução de situações-problema que propiciassem uma vivência comunitária, não havendo, assim, uma "vivência de participação popular na coisa pública” (Freire, 1967, p. 79). Essa falta de participação dificulta a constituição da consciência, desfavorecendo o ambiente democrático.

Não poderíamos, dentro destas circunstâncias, marchar para formas de vida democrática, que implicava num alto senso de participação nos problemas comuns. Senso que se "instala" na consciência do povo e se transforma em sabedoria democrática (Freire, 1967, p. 79).

A questão da não vivência democrática tornou-se desfavorável à solidariedade entre os indivíduos, fazendo com que cada um somente se abrisse para a solidariedade familiar, dificultando o desenvolvimento de um valor democrático.

Para a formação dessa consciência, é necessário que o homem e a mulher sejam envolvidos em determinadas condições, nas quais estejam engajados no debate para a solução dos problemas que são coletivos. Para tanto, é necessário que se tenha conhecimento da coisa pública e que tenham a oportunidade de participar da construção dessa sociedade.

Cada vez mais nos convencíamos ontem e estamos convencidos hoje de que, para tal, teria o homem brasileiro de ganhar a sua responsabilidade social e política, existindo essa responsabilidade. Participando. Ganhando cada vez maior ingerência nos destinos da escola do seu filho. Nos destinos do seu sindicato. De sua empresa, através de agremiações, de clubes, de conselhos. Ganhando ingerência na vida do seu bairro, de sua Igreja. Na vida de sua comunidade rural, pela participação atuante em associações, em clubes, em sociedades beneficentes. (Freire,1967, p. 100).

Para Freire, aprender democracia é viver a democracia. Este saber se incorpora ao homem e à mulher pela experiência demonstrada no dia-a-dia de quem vive e exerce o seu direito de participar. Nesse sentido, destacamos que “é próprio da consciência crítica a sua 
integração com a realidade” (Freire, 1967, p. 114). Sendo assim, o homem e a mulher tornam-se sujeitos do mundo, pois essa conscientização possibilita inserir-se no processo histórico como sujeito e não mais como objeto, como aquele que tem uma consciência servil, como destacou Paulo Freire, inicialmente, em seu livro "Pedagogia do Oprimido”.

Freire (1987) nos mostra que a consciência crítica faz com que os trabalhadores tenham a capacidade de reconhecer a realidade opressora e, para se libertar, é necessário uma "práxis autêntica” (p.38), isto é uma ação baseada na reflexão para que seja possível transformá-la.

Quanto mais as massas populares desvelam a realidade objetiva e desafiadora sobre a qual elas devem incidir sua ação transformadora, tanto mais se "inserem" nela criticamente. (Freire, 1987, p. 40).

A classe dominante deixa os trabalhadores pensarem que eles podem fazer escolhas. Faz com que eles pensem que o opressor oferece vantagens para os oprimidos (classe trabalhadora), mas, na verdade, o opressor faz concessões para que os oprimidos tornem-se mais subservientes e ainda fazem com que eles valorizem essas ações dos opressores. Para se tornarem livres, os oprimidos têm que reconhecer que são explorados. A partir dessa tomada de consciência de sua opressão, eles se tornarão livres da manipulação dos opressores.

Para Coutinho (2000), a classe dominante pode, em determinadas situações, utilizar-se (por causa da disputa e da luta de classes) das políticas sociais para desmobilizar a classe trabalhadora e tentar cooptá-la. Então, para que a classe trabalhadora não seja manipulada, é necessário tomar consciência de que as conquistas sociais fazem parte da luta de classes e que, portanto, quem conseguiu a obtenção desses direitos sociais e políticos foram os próprios trabalhadores.

Para acontecer essa libertação, há que se estabelecer uma relação de diálogo com a classe trabalhadora, uma vez que essa, durante toda a nossa história, foi rebaixada como aquela que não sabe pensar ou decidir e que “alguém” tem que fazer isso por ela. Esse preconceito tem que ser quebrado pelo próprio trabalhador, a partir de seu próprio pensamento, para que desalienado, possa alcançar a consciência crítica. Por isso, Freire defendia que “[o] diálogo crítico e libertador, (...), que supõe a ação, tem que ser feito com os oprimidos, qualquer que seja o grau em que esteja a luta por sua libertação.” (Freire, 1987, p. 52). 
Nesse sentido, o processo educativo torna-se uma tarefa na qual, educador e educando, ou, liderança e massa, sejam ambos os sujeitos desse processo, sendo capazes de entendê-lo, de conhecê-lo, mas também de recriá-lo de forma crítica. "Deste modo, a presença dos oprimidos na busca de sua libertação, mais que pseudoparticipação, é o que deve ser: engajamento.” (Freire, 1987, p. 56). Pode-se, portanto, afirmar que a tomada de consciência se dará por intermédio da reflexão de temas que façam parte da realidade de cada cidadão, refletindo e agindo sobre o local onde está inserido, podendo identificar as suas dificuldades e os motivos pelos quais essas dificuldades existem, dando suas opiniões e decidindo como interferir nesta situação. Isso traduz a relação teoria-práxis, ou no dizer de Paulo Freire: ação-reflexão-ação, que viabilizam o processo de desalienação da realidade.

O importante, do ponto de vista de uma educação libertadora, e não "bancária”, é que, em qualquer dos casos, os homens se sintam sujeitos de seu pensar, discutindo o seu pensar, sua própria visão do mundo, manifestada implícita ou explicitamente, nas suas sugestões e nas de seus companheiros. (Freire, 1987, p. 120)

Para Freire, é pelo diálogo, ou usando o seu próprio termo, é na teoria dialógica da ação que os homens e as mulheres se descobrem como sujeitos podendo, assim, agir para a transformação da sua realidade em colaboração e em solidariedade com os oprimidos. Ainda que essa ação signifique, freqüentemente, luta contra os interesses dominantes.

\section{EDUCAÇÃO POLÍTICA PARA A PARTICIPAÇÃo}

Adotando a concepção freireana de engajamento e reflexão sobre sua ação para alcançar a conscientização, faz-se uma reflexão, juntamente com outros autores, sobre a participação política e o processo de aprendizagem que ela proporciona com sua prática.

Num Estado democrático tem-se como base a participação das pessoas no processo de decisão dos assuntos que são de interesse público. Benevides demonstra essa prática para a educação política, a qual faz com que o cidadão seja ativo e se desenvolva no âmbito da participação popular. Para Benevides, aprende-se a votar, votando.

Nessa mesma linha de pensamento, destacam-se as palavras de Bobbio sobre o valor do voto no processo de educação política:

A participação no voto tem um grande valor educativo: é através da discussão política que o operário (the manual labourer), cujo trabalho é 
repetitivo e cujo ambiente de fábrica é angustiante, consegue compreender a relação entre eventos distantes e seu interesse pessoal e estabelecer relações com cidadãos diversas das suas cotidianas relações de trabalho, tornando-se, assim, membro consciente de uma grande comunidade. (Bobbio,1988, p. 69).

Para que esse engajamento e conscientização possam acontecer, é necessário que sejam garantidas ao indivíduo as informações e os espaços de participação popular, para que possam vivenciar essa cidadania, que Benevides destaca como sendo ativa.

Segundo a autora (1994), há uma diferenciação entre o cidadão que é mero eleitor e o cidadão que exige a participação de forma igualitária. O primeiro é aquele que só obedece às leis e contribui para que a ordem estabelecida permaneça, sendo esse tipo de cidadão que a classe dominante quer gerar, isto é, aquele que vota e volta para casa sem criticar nada. O segundo reivindica seus direitos e cria espaços sociais para se conquistar novos direitos exercendo, assim, a cidadania ativa.

A autora também destaca a importância de se criar mecanismos de informação e de organização para que a participação popular possa acontecer em um ambiente democrático, sendo a educação política uma educação para a participação. Para tanto, faz-se necessária uma mudança de mentalidade, como se mostra destacado abaixo:

A democratização em nosso país depende, nesse sentido, das possibilidades de mudança nos costumes - e nas "mentalidades" - em uma sociedade tão marcada pela experiência do mando e do favor, da exclusão e do privilégio. A expectativa de mudança existe e se manifesta na exigência de direitos e de cidadania ativa; o que se traduz, também, em exigências por maior participação política - na qual se inclui a institucionalização dos mecanismos de democracia semi-direta. (Benevides, 2003, p. 194).

Cada espaço aberto de discussão com a população sobre interesses da vida pública, faz com que esse cidadão participe de discussões e se envolva com o tema, tornando-o um sujeito do processo. Esse envolvimento do cidadão com o que é público faz com que a democracia participativa aconteça e possibilite a educação política.

É bom lembrar que a educação política através da participação em processos decisórios, de interesse público - como em referendos, plebiscitos e iniciativas populares -, é importante em si, independente dos resultados do processo. As campanhas que precedem às consultas populares têm uma função informativa e educativa, de valor inegável, tanto para os participantes do lado “do povo”, quanto para os próprios dirigentes e lideranças políticas. (Benevides, 2003, p. 198). 
Pode-se destacar, baseado nas concepções já citadas Benevides, Chauí, Freire, Coutinho e Canivez, que a educação para a cidadania ou para a vivência política deve fazer com que o indivíduo seja sujeito social, perdendo a noção de objeto ou ser passivo, em que só recebe os "benefícios” da classe política. Sua participação política necessita de espaços públicos para sua realização, pois estes são privilegiados para esta participação. O cidadão deve ter acesso às informações para que possa exercer a cidadania ativa e criar novos elementos culturais, potencializando a sua criatividade, conhecendo a história de luta dos povos pela realização de seus direitos, para que não o aceite como sendo mera concessão da classe dominante. Seu processo de formação deve ser crítico e este deve se interessar em assumir a vivência deste processo, tendo a liberdade, a igualdade e a solidariedade como princípios componentes do conceito de cidadão. A educação política é um direito de todos, bem como a participação nas decisões públicas e esta educação política se dá principalmente pela participação direta dos cidadãos e cidadãs.

Levando em consideração os pressupostos acima destacados, o presente trabalho pretende verificar que representações sociais os cidadãos fazem da sua vivência em alguns espaços democráticos estabelecidos pelo poder público e em que medida e de que forma, os mesmos consideram essas experiências educativas. 


\section{CAPITULO 2}

\section{PARTICIPAÇÃO POPULAR NAS ADMINISTRAÇÕES PÚBLICAS}

Há, hoje em dia, uma grande discussão a respeito da participação popular nas decisões de planejamento e políticas públicas. Várias experiências de Prefeituras Municipais de caráter democrático e popular, vivenciam ou vivenciaram essa experiência de envolvimento da população nas decisões e no controle de políticas públicas municipais, instaurando assim, um processo de democratização do poder local.

O Brasil é um país com contrastes muito significativos no que diz respeito à desigualdade. É um dos primeiros países do mundo em termos de crescimento econômico e um dos últimos em distribuição de renda, fazendo com que grande parte de sua população viva na miséria. Em sua História, sempre se destacaram os heróis das elites, sem qualquer referência às lutas de seu povo.

Podem ser destacadas as lutas dos movimentos sociais no Brasil que se mobilizavam em torno de questões como a reforma agrária, a educação, a saúde, os reajustes salariais dos trabalhadores através de movimentos grevistas. Esses movimentos, na sua maioria, foram sufocados e reprimidos pelo golpe militar de 1964, a partir do qual o país passou por um processo de despolitização e de não participação popular.

A partir de meados dos anos setenta, constata-se uma retomada mais aparente da organização da sociedade civil, que ressurge para reivindicar os direitos sociais, civis e políticos que lhes haviam sido confiscados pela ditadura militar. Esses homens e mulheres que criaram grupos de resistência através de novas associações, sindicatos e partidos políticos, assumiram o papel de "sujeitos sociais" coletivos, influenciando no processo de redemocratização do nosso país. As Comunidades Eclesiais de Base, os movimentos de saúde e de alfabetização e os clubes de mães e Sindicatos demonstravam a capacidade de organização e da utopia de uma sociedade mais justa com base numa transformação da relação Estado-Sociedade (Sader,1988). Essa organização estava baseada na demanda existente de melhorias na qualidade de vida das pessoas, iniciando-se, muitas vezes, pela reivindicação de melhorias nos bairros e nas suas cidades.

A participação na vida social aparece, então, para os trabalhadores, como um mecanismo de construção da história e de mobilização para modificar as suas condições sócio-econômicas e políticas. A discussão de participação popular, já na década de 1980, 
passava pela questão das pessoas dos movimentos populares se sentirem ou não participantes ativos da transformação, do processo democrático e sujeitos de sua própria história.

Para isso, é necessário criar espaços de representação dos interesses sociais, formando regras de convivência política para afastar as práticas autoritárias do poder público existentes no Brasil. Pode-se apontar a importância dos espaços e canais de participação direta para a garantia dos direitos dos setores sociais.

Essas experiências de participação popular citadas ajudaram na conquista de administrações municipais eleitas com o apoio das organizações populares. As Prefeituras Municipais, de caráter democrático e popular, abriram canais de participação que geraram debates sobre o papel da participação da população no processo de democratização do poder local, no que diz respeito ao planejamento e às decisões de políticas públicas, visando romper com a tradição autoritária e elitista que influencia o poder público.

As administrações municipais, democráticas e populares, que têm como base de apoio os movimentos populares, começam a reconhecer e a incentivar a participação da sociedade no processo de interlocução nos espaços públicos de decisões das políticas municipais, dando legitimidades às demandas populares, valorizando a cidadania, como um modelo democrático de gerenciamento público.

Percebe-se, assim, que é estabelecido um novo vínculo com o cidadão, isto é, o processo de participação dos indivíduos na administração pública faz com que seja revista sua atuação perante o processo democrático. A pessoa passa de simples eleitor a cidadão que exige, fiscaliza e colabora com a construção da cidade. Dá-se então, como diz Benevides (1994, p.14), o surgimento de “novos sujeitos políticos, novos cidadãos ativos”.

Para Benevides (1994), a concepção de cidadania ativa se dá na participação direta dos cidadãos e essa participação popular ocorre na vivência política, na qual se aprende a participar e exercer sua cidadania participando. Também entende a participação popular como uma “escola da cidadania” e, para que isso ocorra, é necessário garantir canais abertos de participação. Nesse sentido, os canais abertos de participação popular ajudarão na formação de novos “sujeitos políticos”. (Benevides,1994, p.18-9)

Os estudos disponíveis sobre as administrações municipais de caráter democrático e popular (Polis, 1994, 2000), começam a se pautar e adotar práticas oriundas de movimentos sociais, como, por exemplo, os Conselhos Populares de Saúde na Zona Leste 
de São Paulo, Conselho Popular do Orçamento em Osasco, Assembléia do Povo, em Campinas, entre outros. (Daniel, 1994, p.23)

Os mecanismos de que as administrações municipais dispõem para tornar sua gestão democrática e participativa podem ter as mais variadas denominações, tendo como canais de participação os fóruns, as comissões e os conselhos dos mais diversos tipos (os municipais e os gestores de unidades).

Os conselhos têm por objetivo envolver a população usuária dos equipamentos da prefeitura na elaboração dos planos de ação, acompanhamento, fiscalização das atividades desenvolvidas e nas decisões de âmbito local. O contato diário com a população que jamais teve experiência organizativa torna ainda mais desafiante atrair a sua intervenção no equipamento, restituindo o caráter público aos serviços da prefeitura. (Villas Boas, 1994, p. 58)

O indivíduo deve ser entendido como sujeito da participação, isto é, como cidadão. Para tanto, pode-se destacar que, para a democracia, é também importante que o cidadão deve ter o direito de decisão e não apenas de ser consultado sobre suas demandas. Nesse caso, o cidadão que participa dos mecanismos de democratização da gestão pública, como por exemplo, os conselhos, devem também deliberar sobre os recursos a serem investidos nos seus setores. A constituição de um processo de decisão sobre o orçamento público, como o Orçamento Participativo, é de extrema necessidade para valorizar e decidir sobre as demandas de cada setor organizado. É nesse contexto de ressignificação da democracia, de reconstrução e de participação popular no país, que destacamos o OP como uma das formas de participação popular que foram abertas no final do século $\mathrm{XX}$, tornando-se assim uma novidade, já que escolher a destinação dos recursos públicos é uma questão nova no país.

Por fim, é importante ressaltar neste capítulo, ainda que de forma breve, a origem da participação popular no processo de redemocratização e sua influência na formação de Administrações Públicas que se propuseram a ter uma forma democrática de governar as Cidades, demonstrando o seu posicionamento perante o poder público, na busca de transformações em relação ao clientelismo e fisiologismo existentes no país. 


\section{ALTERNATIVAS DE PARTICIPAÇÃO POLÍTICA}

São apresentados a seguir alguns espaços onde a população tem exercido seu direito de participar das decisões políticas, bem como a divisão do poder no que diz respeito à administração pública. O mecanismo a ser analisado será o Orçamento Participativo e sua interface com outras formas de participação que, neste caso, serão os Conselhos.

\section{CONSELHOS}

Mais recentemente na História brasileira, os Conselhos tiveram uma forte aclamação popular para que fossem contemplados na Constituição Federal de 1988, que foi denominada de cidadã, uma vez que disciplina os direitos de cidadania de todos os brasileiros. Isso se deu pela participação da sociedade, que estava ansiosa por instrumentos de participação e de pressão ao Estado para realização e garantia de seus direitos sociais.

O objetivo que motivou a criação dos Conselhos e que também aparece como um desafio é o de controle social da Gestão Pública para que exista o melhor atendimento à população.

Os Conselhos não são novidades, pois, ao buscar na História outras formas de conselhos, Gohn nos lembra que:

Há experiências internacionais desde o século passado, como o conselho da Comuna de Paris, ou do início deste século (XX), como os conselhos dos Sovietis, Conselhos dos Operários de Turim, conselhos Alemães, os antigos conselhos Iugoslavos nos anos 50 ou os conselhos americanos do pós-guerra. No Brasil, houve experiências históricas como conselhos comunitários nos anos 60 e no final dos anos 70, ainda na fase do regime militar, ou os "conselhos dos notáveis" que atuavam junto às instâncias governamentais. Nos anos 80 os conselhos populares foram a novidade no cenário político. Nos anos 90, foram criados os conselhos gestores institucionais, previstos a partir da Constituição de 88. (Gohn, 2000, p. 35).

Os Conselhos têm como característica fundamental, o fato de serem espaços de participação da população como canal de diálogo com o Estado, sendo um mecanismo que a sociedade tem para interferir nas políticas públicas de forma democrática e descentralizadora. 
Como se pôde verificar anteriormente, a forma de participação por intermédio dos conselhos não é nova, mas o que faz a diferença é a questão dos conselhos serem de caráter deliberativo, pois o “papel deliberativo sobre a política pública e a dimensão políticoinstitucional que assumem é que representa a novidade nessa experiência conselhista atual.” (Raichelis, 2000, p. 43).

Outra questão que a autora destaca como sendo de fundamental importância sobre a concepção de conselho é a paridade. Esta não deve ser somente numérica, mas de representatividade, de correlação de forças. Também se deve tomar cuidado para que a participação não se resuma à representação, na qual o membro do conselho não retorna mais à sua base para discutir conjuntamente com seus pares a respeito das questões levantadas no conselho.

Com isso entramos na discussão sobre a participação popular, pois os Conselhos são espaços importantes de democratização e, mesmo com todos os problemas apontados, são conquistas da sociedade civil. (Raichelis, 2000, p. 44).

Os Conselhos são importantes instrumentos de aperfeiçoamento da democracia. Eles se tornaram mecanismos valiosos para a constituição e consolidação de espaços públicos, nos quais os sujeitos sociais exercem sua cidadania, podendo negociar com o Estado as políticas públicas e serviços sociais de qualidade.

\section{ORÇAMENTO PARTICIPATIVO: ESPAÇO DE PARTICIPAÇÃO POLÍTICA}

Apesar dessas lutas e mobilizações, não se pode deixar de enfatizar a postura tutelar que a elite brasileira sempre teve em relação aos trabalhadores. A história brasileira é marcada pelo clientelismo, pelo corporativismo e também pelas relações fisiológicas. As iniciativas de organização e de mobilização sempre foram abafadas pelas épocas de ditaduras vividas no país. Nos anos de 1970, tem início uma mobilização da sociedade de forma organizada, principalmente nas grandes cidades e suas periferias. Por meio de sua luta, essa sociedade organizada vai garantir, na década de 80, uma participação intensiva no Processo Constituinte, gerando, assim, uma Constituição que garante a participação popular no que diz respeito ao controle das políticas públicas e sua gestão. 
No Brasil, a Constituição de 1988 estabelece a participação cidadã e a soberania popular como princípio fundamental e abre diversos mecanismos para esta participação como o plebiscito, o referendo, o projeto de iniciativa popular e os conselhos.

Com a reorganização dos movimentos populares e as eleições de Administrações Públicas de Partidos Políticos progressistas surgiu a necessidade de espaços institucionais de participação popular. Em cidades como Vitória e Vila Velha (ES), em Uberlândia (MG), em Belo Horizonte (MG), Piracicaba (SP), Santo André (SP) e em Porto Alegre (RS) o canal aberto para a participação popular foi para as experiências de discussão do Orçamento Municipal com a população. Vale ressaltar que, em pesquisa feita pelo Fórum Nacional de Participação Popular, tivemos entre os anos de 1997 a 2000, cerca de 140 municípios do Brasil que haviam iniciado um processo de participação com o objetivo de implantação do Orçamento Participativo.

Em Porto Alegre, capital gaúcha, surge o Orçamento Participativo como marca de participação popular. O Orçamento Participativo vem ao encontro da necessidade de espaços democráticos de participação política, de controle social e da luta pela conquista dos direitos sociais.

As experiências de orçamento participativo têm se pautado na idéia de uma nova ética no trato da coisa pública, tanto por parte dos governantes como da sociedade civil, centrada na responsabilidade social, no reconhecimento da diversidade e da pluralidade, na idéia da publicização de conflitos entre interesses sociais, de forma a imprimir uma certa transparência às ações do governo, e na garantia ao acesso às informações sobre a gestão pública. A idéia de partilha de poder implica a participação da população não só na elaboração mas também na decisão das políticas públicas. (Cepam³ ${ }^{3}$ 1998, p. 13).

A idéia de Orçamento Participativo focaliza a importância de ampliar os espaços de participação popular e de garantia do fortalecimento da democracia, pois esta implica em espaços de participação direta, de divisão do poder e de descentralização das decisões que dizem respeito à elaboração e execução das políticas públicas. A discussão do orçamento público não tem um caráter somente de participação, mas também serve para democratizar a elaboração de orçamentos feita em gabinetes. Sánches nos lembra que:

O surgimento do OP configura uma nítida ruptura com o clientelismo na política brasileira, principalmente com a tradição política fortemente marcada pelo patrimonialismo e pelo autoritarismo burocrático. O Partido dos trabalhadores tem sido identificado como o principal agente dessa inovação democrática e institucional. A maioria dos partidos

\footnotetext{
${ }^{3}$ Centro de Estudos e Pesquisa de Administração Municipal - Fundação Prefeito Faria Lima.
} 
políticos brasileiros tem reagido com críticas e oposição à difusão da experiência do OP no país. Ele tem se configurado como proposta dos setores de esquerda, críticos à organização tradicional da política brasileira. (Sanches, 2002, p. 14).

O OP surge como um modelo de ruptura com a tradição política brasileira pelos Partidos Políticos progressistas (PT, PC do B, PSB). Nesse caso, a principal referência é o Partido dos Trabalhadores e a experiência que se desenvolveu no município de Porto Alegre (RS) e se consolidou. O OP propicia o aprendizado do funcionamento da máquina pública, fazendo com que se possa romper com o caráter tecnocrático exclusivo de elaboração de planos de investimentos. O Orçamento Participativo é um instrumento de gestão democrática que pode proporcionar à população o acesso ao debate, às informações, à reivindicação e à conquista de serviços públicos, visando à melhoria da qualidade de vida bem como a redistribuição de renda.

O orçamento participativo tem se constituído também em um poderoso instrumento de redistribuição de renda. Embora muitas experiências de OP hoje em vigor tenham começado recentemente, no caso do município de Porto Alegre, têm sido feitos estudos com o objetivo de avaliar o efeito redistributivo da aplicação do Plano de Investimento, propostos pelo Orçamento Participativo e executados com prioridade por esta administração municipal. (Sanches, 2002, p. 15).

Tendo como princípio a soberania popular, o OP obriga que se respeite a decisão e a deliberação popular para a implementação e execução de obras e políticas públicas, uma vez que decide com os representantes do Governo, os recursos financeiros para essas demandas. Outro princípio é a transparência, condição básica para o controle social e vinculado à prestação de contas que deve ser realizada pelo Poder Público.

Com a experiência e o aprofundamento dos debates, esses espaços públicos acabam por superar os corporativismos egoístas e os particularismos limitadores, que aliás brotam inevitavelmente num primeiro momento, em razão de uma longa história de exclusão e de ausência de decisões e de projetos coletivos. Assim, as pessoas lutam não apenas pelas demandas de suas ruas e de seus bairros, mas adquirem uma visão integral de sua cidade, de seu estado e de seu país. Portanto, tornam-se cidadãs e cidadãos solidários, com consciência crítica e preocupação social, entendendo os processos de dominação, combatendo-os e se reconhecendo como construtores de uma nova sociedade. (Dutra,2001, p.10).

Como se pode verificar, o que está em jogo é o protagonismo das pessoas, fazendo a História e que reconhecem nesse processo histórico, a sua transformação pessoal e a transformação da sociedade. O Orçamento Participativo se torna um novo centro decisório 
juntamente com o Executivo e com o Legislativo, conforme nos lembra Genro (1997). Ele potencializa o exercício dos direitos da cidadania e motiva os cidadãos a serem mais exigentes e mais críticos. Cria, então, uma nova relação com o Estado, que faz com que a população conheça o seu funcionamento e que exerça sua cidadania, reconceituando a própria idéia de Estado e suas relações.

\section{EXPERIÊNCIAS ANTERIORES DE ORÇAMENTO PARTICIPATIVO}

Como as experiências bem sucedidas de OP das cidades de Porto Alegre/RS e Santo André/SP se constituíram em referência nacional, consideramos importante para a discussão apresentar um breve resumo, já que, em algum grau, elas interferem, também, na experiência realizada na cidade de Araraquara, objeto desta pesquisa.

A experiência da capital gaúcha foi a primeira a implementar esse mecanismo de participação denominado OP e tem sido o referencial de implantação para muitas experiências em diversos municípios onde existe o OP. A cidade de Santo André foi escolhida, por estar situada no Estado de São Paulo, onde também se localiza a cidade de Araraquara e pela tradição petista de reunião de seus Prefeitos, para a troca de experiências e discussão das experiências que avançam a Gestão democrática.

No histórico brasileiro de elaboração de orçamentos públicos, as características mais lembradas pela população são: a corrupção, o clientelismo político, o patrimonialismo, e o poder de decisão concentrado nas mãos de poucos. Com o OP, há uma diferenciação nesse processo, pois quem decide a respeito dos gastos públicos (na área de investimento) é a população que participa das suas assembléias, debatem as prioridades e definem onde serão feitos os investimentos da Cidade.

Boaventura de Souza Santos, ao se referir ao OP de Porto Alegre, define-o como:

Uma forma de administração pública que procura romper com a tradição autoritária e patrimonialista das políticas públicas, recorrendo à participação direta da população em diferentes fases da preparação e da implementação orçamentária, com uma preocupação especial pela definição de prioridades para a distribuição dos recursos de investimento (Santos, 2002, p. 466)

O autor continua sua reflexão destacando três princípios para o OP. O primeiro é que todo o cidadão tem o direito de participar, sendo que as organizações e instituições não 
detêm nenhum tipo de prerrogativa. O segundo princípio é a existência de regras para a participação, propiciando uma combinação da democracia direta e da democracia representativa. E o terceiro, é a distribuição dos recursos de investimento, baseados na combinação de critérios gerais com critérios técnicos, observando-se as rotinas e as restrições legais, financeiras e jurídicas que cabem ao Executivo respeitar.

Avritzer (2002) defende que a criação do OP de Porto Alegre está vinculada à ação de atores sociais organizados, que se destacaram num forte movimento na Cidade para que se debatesse a questão orçamentária.

O processo de criação do Orçamento Participativo como uma instância de deliberação sobre o orçamento está ligado à ação de múltiplos atores e a superposição de dois elementos. Primeiro, à existência de novos elementos culturais nas comunidades locais, fato esse ligado ao desenvolvimento de um forte movimento comunitário na cidade de Porto Alegre. Não foi por acaso que esses movimentos foram os primeiros atores capazes de identificar a contenção na questão do orçamento. Em segundo lugar, também é importante destacar o fato de que a capacidade da sociedade civil brasileira de recuperar a idéia da cidadania e incorporá-la na constituição através da participação de associações e atores comunitários no processo de decisão sobre questões locais foi de fundamental importância para o próprio processo de inovação institucional (Avritzer, 2002, p.575)

Fedozzi (1999), em seu estudo sobre o OP de Porto Alegre, levanta a hipótese de que esse mecanismo gera mudanças na gestão governamental, na qual a realização das consultas populares apresenta o outro elemento de contrato, isto é, demonstra a partilha de poder sobre o orçamento público, utilizando a participação dos munícipes. Por outro lado, este mecanismo também faz com que o governo torne as contas públicas transparentes, na medida em que realiza as prestações de contas não só para os tribunais de Contas, mas para a população. Outra característica destacada é a dinâmica institucional, a partir da qual a população intervém no processo de investimento dos recursos públicos. Essa dinâmica é exercida por meio de regras, rituais e critérios que normatizam e tornam o processo transparente.

Essa análise de Fedozzi sobre o OP de Porto Alegre acaba caracterizando, também, outros OPs de diversos municípios, pois a base desse programa se torna genérica, tendo algumas modificações e adequações de metodologia devem ser aplicadas de acordo com cada realidade.

Podemos afirmar, portanto, que o OP tem as seguintes características: a divisão do município por regiões; a definição de critérios de participação da população, bem como, da 
escolha de representantes; o estabelecimento de critérios para o atendimento das prioridades eleitas nas regiões; e as regras de funcionamento das Plenárias, bem como das competências das instâncias de representação, como o Conselho do OP, por exemplo.

\section{Orçamento Participativo de Porto Alegre}

O OP de Porto Alegre ${ }^{4}$ tem como referência histórica a mobilização dos movimentos comunitários da Cidade, que se organizaram e pressionaram o Governo Municipal para que disponibilizasse o orçamento municipal para a discussão com a população.

Com a eleição do Partido dos Trabalhadores, em 1888, o Prefeito Olívio Dutra desenvolve a idéia de mudar a concepção da Administração local, aderindo à discussão do orçamento municipal e desenvolvendo o OP. É importante ressaltar que o PT se manteve no governo dessa Cidade durante quatro mandatos, ou seja, por 16 anos, conservando, em todas elas, o OP, mas modificando-o, de acordo com as necessidades apresentadas em cada uma das Gestões. Essa breve exposição foi baseada, fundamentalmente, nos dados da Prefeitura Municipal de Porto Alegre e nos autores Avritzer (2002) e Fedozzi(1999).

O OP de Porto Alegre baseia-se no processo de decisão da população sobre os investimentos a serem realizados pela Prefeitura Municipal. Para realizar esse processo, o OP dessa cidade estabeleceu algumas etapas:

a) Primeira rodada de Assembléias Regionais:

A cidade de Porto Alegre foi dividida em 16 regiões administrativas. Nessa primeira fase são realizadas 16 assembléias regionais e 6 Plenárias temáticas. Os temas estabelecidos para as Plenárias Temáticas são: 1) circulação e transporte; 2) educação e lazer; 3) cultura; 4) saúde e assistência social; 5) desenvolvimento econômico e tributação; 6) organização da cidade, desenvolvimento urbano e ambiental.

Essas assembléias são abertas a toda a população e à representação de qualquer instituição civil. Também participam o Executivo Municipal (Prefeitos e Secretários) e são coordenadas por integrantes do Gabinete de Planejamento (Gaplan) e da Coordenação das

\footnotetext{
${ }^{4}$ Essa experiência faz referência aos anos de OP realizados pelo Governo PT (Partido dos Trabalhadores), de 1989 a 2004. No ano de 2005, a Prefeitura passa a ser administrada pelo Partido Popular Socialista (PPS) que manteve o OP.
} 
Relações com a Comunidade (CRC), que são membros da Administração Municipal. Têm participação nas Assembléias, os membros do Conselho do OP, dos Conselhos Populares e das demais entidades comunitárias.

A primeira rodada do OP tem como dinâmica

[...] a prestação de contas, pelo Executivo, do Plano de Investimento do ano anterior e apresentação do Plano aprovado para o orçamento vigente; a avaliação do Plano de Investimento do ano anterior pelos moradores da região e/ou participantes das temáticas e pelo Executivo; a primeira eleição para o Fórum de delegados, mediante o critério de um delegado a cada vinte pessoas presentes na assembléia. (Fedozzi, 1999, p. 118)

Em preparação a essa Assembléia, a população se organiza autonomamente, isto é, sem a presença ou a coordenação de pessoas da Prefeitura Municipal. Os participantes fazem o levantamento das demandas que irão ser reivindicadas pelos moradores ou entidades populares e discutem a escolha dos representantes da região para Delegados e Conselheiros do OP.

b) Rodada intermediária:

As reuniões intermediárias ocorrem entre a primeira e a segunda rodada de Assembléias oficiais. São organizadas pelos próprios moradores da região ou participantes das Assembléias Temáticas, tendo a presença de membros da Prefeitura Municipal. Nessa reunião, as demandas são hierarquizadas pela população participante. Também são escolhidos os Delegados do OP, mediante critérios estabelecidos que, em geral, propõem a eleição de um delegado para cada dez pessoas presentes, na maior reunião realizada pela Região ou pela Assembléia Temática.

c) Segunda rodada de Assembléias Regionais e Temáticas:

Segundo Fedozzi, essa reunião obedece os seguintes passos:

1.O executivo apresenta os principais elementos da política tributária e de receitas e a política de despesas que devem direcionar a elaboração da peça orçamentária do próximo ano, bem como apresenta a proposta de critérios para a distribuição de recursos de investimentos; 2. Os representantes comunitários apresentam para a assembléia dos moradores e para o Executivo as demandas priorizadas que foram aprovadas nas reuniões intermediárias das regiões e temáticas; 3. São eleitos os representantes ao Conselho do Orçamento Participativo, através da escolha de dois membros titulares e dois suplentes em cada região e temática. (Fedozzi, 1999, p.120) 
Depois de realizadas as etapas de Assembléias Populares, ficam formadas as instâncias institucionais de participação, isto é, o Fórum de Delegados e o Conselho do Orçamento Participativo (COP). O Fórum de Delegados é um órgão consultivo, de controle e de mobilização social. O COP é composto por dois membros titulares de cada Região e Assembléia Temática e dois suplentes; um Delegado titular e um suplente do Sindicato dos Trabalhadores Municipais de Porto Alegre; um Delegado e um suplente da União das Associações de Moradores de Porto Alegre; um Delegado do CRC (sem direito a voto) e um Delegado do Gaplan (sem direito a voto). Os conselheiros podem ser reeleitos apenas para um mandato. As atribuições do COP são:

\footnotetext{
Debater e aprovar a proposta orçamentária do município, confeccionada pelo Gaplan, tendo como base as decisões sobre a hierarquização e prioridades de obras tomadas nas assembléias intermediárias. Rever a proposta orçamentária final elaborada pela prefeitura; acompanhar a execução das obras aprovadas; discutir os critérios técnicos que inviabilizam a execução de obras aprovadas. (Avritzer, 2002, p.579)
}

Vale ressaltar que existem critérios para a distribuição de recursos seguidos por uma pontuação para definição da prioridade eleita pelos moradores. Os critérios são os seguintes: a) carências dos serviços e de infra-estrutura urbana; b) população em área de carência máxima; c) população total da região do OP; d) prioridade atribuída pela região aos setores de investimentos demandados por ela.

Após a posse do Conselho do Orçamento Participativo (COP), os seus membros participam de um curso sobre Orçamento Público e sua sistemática financeira e contábil. Também elaboram seu cronograma de discussão, devendo isso acontecer na segunda quinzena de julho de cada ano. No mês de agosto, o Gaplan elabora a matriz orçamentária que será a base da proposta orçamentária do exercício seguinte. No mês de setembro, o COP discute e delibera a matriz orçamentária e o detalhamento da proposta orçamentária para os programas de serviços e investimentos votados nas Plenárias.

O final da redação da proposta orçamentária é realizado pelo Gaplan, no final de setembro, tendo como base a aprovação do COP. Essa proposta é entregue na Câmara de Vereadores, no prazo estabelecido pela Constituição Federal, ou seja, até 30 de setembro. Os vereadores têm o prazo de $1^{\circ}$ de outubro a 30 de novembro para discutir e votar a proposta orçamentária, realizando, obrigatoriamente, as Audiências Públicas.

No período de $1^{\circ}$ de outubro a 30 de dezembro o COP, o Gaplan, a CRC e as demais secretarias elaboram o Plano de Investimento, baseado na proposta orçamentária 
enviada para a Câmara de Vereadores, fazendo a análise técnica, legal e financeira das demandas.

No primeiro semestre do ano seguinte, o COP realiza sua última etapa, que é a de acompanhamento e fiscalização da execução orçamentária e das estimativas de receita do município. Nesse mesmo momento, os Delegados fazem um acompanhamento mais direto das obras e serviços que vêm sendo realizados, atendendo às decisões de suas Regiões e Assembléias Temáticas. Também nesse período, os Delegados, Conselheiros e Representantes do município do CROPs e CTs, ou sejam, os coordenadores regionais e temáticos do OP, começam a organização e mobilização para o próximo ciclo do OP.

\section{Orçamento Participativo de Santo André}

No município de Santo André, o OP foi implementado na primeira Gestão do Prefeito Celso Daniel (PT), ou seja, de 1989 até 1992. Esse processo foi interrompido pela derrota eleitoral do PT no período de 1993 a 1996. O OP foi retomado no mandato seguinte (1997-2000), com a segunda vitória de Celso Daniel (PT), que foi reeleito para o período de 2001-2004, mas que não terminou seu mandato, pois foi assassinado no ano de 2002. Seu Vice, João Avamileno (PT), assumiu a Prefeitura Municipal, administrando-a até o final de 2004, sendo eleito novamente para a Gestão de 2005-2008.

Na primeira gestão do PT, a Prefeitura Municipal de Santo André desenvolveu práticas de participação popular, através de diversos instrumentos democráticos, inclusive o Orçamento Participativo.

O OP, no período de 1989-1992, era de caráter consultivo e tinha quatro fases, conforme afirma Pontual em sua tese de Doutorado (2000). A primeira é aquela em que o Prefeito Municipal e os Secretários elaboram uma primeira proposta de Orçamento. Na fase seguinte, o Prefeito Municipal e a Equipe da Prefeitura, discutem essa proposta com a população, através de Reuniões nas Regiões da cidade, reuniões das Plenárias Temáticas e, também, Reuniões especiais com as Entidades. Após essa relação com a comunidade, inicia-se outra fase interna, na qual o Prefeito Municipal, Secretários e Técnicos da Secretaria de Finanças compatibilizam o Orçamento, proposto pela Prefeitura Municipal com as demandas enumeradas pela população nas reuniões. A última fase constitui-se pela entrega do orçamento na Câmara Municipal para a sua tramitação legal. 
Em 1989, foi criada uma Comissão de Fiscalização com cerca de 300 pessoas eleitas pela população, para acompanhar e fiscalizar o cronograma das obras. Em 1991, criou-se a Assessoria de Participação Popular, ligada à Secretaria de Governo, e o coletivo dos Agentes de Participação Popular (APPs). Esses são técnicos e dirigentes das Secretarias que são chamados para estabelecer uma relação com o OP e as outras Secretarias de Governo.

Nessa primeira experiência de OP não existia uma instituição decisória, como o Conselho do Orçamento Participativo, para discussões e deliberações de assuntos das prioridades eleitas.

O OP, na Gestão de 1997-2000, passou por modificações, em função de avaliações da experiência anterior. A partir desse Mandato, foi criada uma estrutura para trabalhar a participação popular no Município. O Núcleo de Participação Popular (NPP) criado fica vinculado ao Gabinete do Prefeito e tem como atribuições:

Elaborar políticas públicas de participação popular e contribuir com os demais órgãos da administração direta e indireta para o desenvolvimento de ações de implementação da marca de governo Participação Popular, assumindo, entre outras ações, a coordenação do processo do Orçamento Participativo. (Pontual, 2000, p. 161)

Pontual descreve a estrutura estabelecida para o NPP: "É formado por um Coordenador Geral, quatro Coordenadores de Programas, seis Agentes de Participação Popular -APPs- que desenvolvem projetos e atividades em distintas Secretarias, além dos funcionários responsáveis pelas tarefas administrativas”. (Pontual, 2000, p. 161)

A Cidade de Santo André foi dividida em 19 regiões, tendo como critério a proximidade geográfica e a facilidade de locomoção, bem como a identidade entre os bairros. Existiam oito Plenárias Temáticas: saúde, educação, habitação, saneamento e meio ambiente, cultura, assistência social, desenvolvimento econômico e geração emprego e renda e funcionalismo.

O processo do OP foi dividido em 2 fases: a primeira fase constitui-se na realização das Plenárias Informativas, nas quais a Prefeitura Municipal faz a prestação de contas financeira e do andamento das obras, explica a composição do orçamento municipal e apresenta o funcionamento do processo do OP.

Entre a primeira e a segunda fase existem reuniões intermediárias, nas quais cada bairro se organiza, de forma autônoma, para elencar as prioridades que serão apresentadas 
na segunda fase. O papel da prefeitura se limita a dar as informações que forem solicitadas pela população.

A segunda fase conta com a presença do prefeito, vice-prefeito e dos secretários. Nesse momento, os representantes do governo apresentam diretrizes para a cidade e a população apresenta as prioridades. Há a intervenção do governo nos casos de prioridades que tenham algum empecilho jurídico ou comentários sobre obras de alto custo. As prioridades votadas nessas plenárias são indicativas para o Conselho Municipal do Orçamento, pois a plenária vota três prioridades para a região e duas de interesse geral da cidade e quem irá definir qual a prioridade será realizada é o Conselho Municipal do Orçamento.

Para a realização da eleição do Conselho Municipal do Orçamento, de acordo com o Regimento do OP, é necessário ter um quorum mínimo de participação na plenária. São estabelecidos $0,05 \%$ proporcionalmente à população de cada região, ao passo que, no caso das temáticas o quorum mínimo era de 100 participantes. Caso a plenária não atinja o quorum, fica assegurado que duas prioridades serão levadas ao Conselho e só poderão eleger um representante titular e suplente para o Conselho, sem direito a voto.

Segundo a estruturação desse Conselho em 1999, temos que:

O Conselho Municipal do Orçamento (CMO) é paritário, composto por 52 integrantes da sociedade civil (26 efetivos e 26 suplentes), eleitos pelo voto direto, e 52 integrantes do governo (26 efetivos e 26 suplentes). Indicados pelo gabinete do prefeito assegurando a presença das diversas secretarias e empresas municipais (Pontual, 2000, p.168)

Analisando o Regimento Interno do Orçamento Participativo de 2006, o OP sofreu algumas modificações. A composição do Conselho diminuiu para 19 membros titulares e 19 suplentes da sociedade civis e os mesmos números para os representantes do governo, totalizando 76 membros. As plenárias deliberativas são bienais, isto é, em um ano as reuniões do OP com a população são para a realização da prestação de contas das obras dos anos anteriores e ações do governo nos bairros, enquanto no ano seguinte são realizadas as plenárias deliberativas, seguindo o processo apresentado anteriormente. Outra modificação é a eleição de três prioridades para a região e uma para a cidade.

A Caravana das Prioridades é um instrumento ainda utilizado para a formação dos conselheiros. Nesse mandato, ela é realizada de dois em dois anos para coincidir com as plenárias deliberativas. Ela possibilita aos conselheiros o conhecimento da cidade e das obras votadas, auxiliando o debate e a priorização das demandas. 


\section{CAPITULO 3}

\section{O DESPERTAR PARA A PARTICIPAÇÃO E EDUCAÇÃO CIDADÃ NO MUNICÍPIO DE ARARAQUARA}

O município de Araraquara, fundado em 22 de agosto de 1817, está localizado na região central do Estado de São Paulo. No ano de 2005, o município teve uma população estimada, pelo Instituto Brasileiro de Geografia e Estatística (IBGE), em 193.634 habitantes. Com o Índice de Desenvolvimento do Município (IDH-M) de 0,830, está em $133^{\circ}$ na classificação nacional, alcançando o IDH-M de longevidade de 0,786, o IDH-M em educação de 0,915 e o IDH-M de renda em 0,789. Tem uma receita orçamentária total de 153.000.000,00 e sua participação no Fundo de Participação dos Municípios é de cerca de 9.500.000,00. O município de Araraquara está na $51^{\circ}$ posição no ranking nacional de municípios para Investimentos, segundo a Revista Exame/2003.

A atividade industrial deste município está baseada na agroindústria. A área do comércio tem grande representatividade empregando cerca de $60 \%$ da mão-de-obra. $\mathrm{O}$ Ensino Superior também merece destaque pela universidade UNESP (Universidade Estadual Paulista) e os institutos de educação superior, UNIARA (Centro Universitário de Araraquara), a UNIP (Universidade Paulista) e as Faculdades Integradas Logatti. Elas agregam cursos de graduação e pós-graduação que atraem alunos de todo o país, tornando Araraquara um pólo de desenvolvimento educacional e cultural.

Apesar dessa estrutura de desenvolvimento, a história deste município é marcada pela política dos coronéis do café que, mesmo com o fim da Velha República, continuavam dominando a política local, estabelecendo seu poder na propriedade da terra e num sistema que favorecia as oligarquias. (Kerbauy, 2000)

Na década de 1950 podemos destacar na política local o surgimento de novos atores políticos, essa nova conjuntura mostra também o fim da hegemonia dos fazendeiros de café, promovendo uma mudança na atividade econômica regional. Com a população se transformando em urbana os setores sociais ligados à indústria, ao comércio e aos serviços passaram a conduzir a cena política local.

Situação e oposição passam a compor uma outra dinâmica. O controle da intermediação não corresponde mais à posse da terra e à ordem social rural. Apesar disso, a base política local continuava assentada na importância política de certas famílias: os Lupo, empresários do setor têxtil (fabrica de meias), e os Barbieri, ligados ao comércio local. (Kerbauy, 2000, p. 98) 
Quando os governos militares instalados em 1964 começaram a permitir eleições municipais para o executivo, o que prevalece é a dependência, caracterizando a política local. Tendo como base a política dos coronéis, outros personagens atuavam na troca de votos, garantindo, assim, a fidelidade administrativa, procurando avigorar a relação clientelista, por meio de concessões de empréstimos, realizações de obras e preenchimento de cargos públicos. Esse período, no qual se reforçava a troca de favores no ambiente político, fortaleceu o clientelismo de massa.

É dentro desse contexto que, com a eleição de um prefeito (no processo eleitoral de 2000) distante da política tradicional, ou mesmo distante das famílias tradicionais, temos uma proposta de Governo Democrático e Popular. Essa frente democrática e popular, formada pelos partidos PT, PSB e PC do B, propõe-se a governar, dividindo o poder com a população, como afirma seu plano de governo para o mandato 2001-2004.

Diante desse panorama, a administração municipal, encabeçada pelo Partido dos Trabalhadores, implementou mecanismos de participação da população para valorizar a gestão democrática e participativa, como o Orçamento Participativo e também a criação de diversos conselhos municipais. Realizou a remodelação dos Conselhos já existentes, que são instituídos por lei federal, além dos Conselhos Gestores das Unidades de Saúde, em cada centro de saúde de bairros e os Conselhos de Escola em cada unidade escolar de ensino fundamental e de educação infantil municipal, como já foi relatado.

Antes de ser discutido o processo do OP em Araraquara, que é o objeto deste estudo, descrever-se-á o processo da implementação dos Conselhos de Escolas e Gestores das Unidades de Saúde, pois estes, além de serem mecanismos de gestão democrática, têm uma interface com o OP. 


\section{A GESTÃO EDUCACIONAL DEMOCRÁTICA}

Atualmente se vive um novo paradigma na Administração Pública e a gestão da escola deve ser vista dentro desses novos princípios de gerência democrática. Tendo em vista a construção de uma sociedade democrática, a escola é o espaço de contribuição para que a democracia se constitua como realidade e não apenas como teoria ou método. A educação deve acompanhar esse processo de implementação da democracia participativa, cujo método é a participação, a discussão e o diálogo. A grande questão colocada por autores como Freire, Lima, Paro, e outros, é como aprender a ser democrático e exercer a participação cidadã em uma escola autoritária, que não discute, e apenas impõe suas idéias.

A democratização da escola pública envolve autonomia dos professores e alunos no papel de construtores da sociedade, e pela atuação destes, como sujeitos do processo pedagógico. Os docentes devem ser capazes de tomar decisões, sejam individuais ou coletivas, para a prática democrática no universo escolar. Sem isso, fica inviável a autonomia da escola para uma prática da "pedagogia da autonomia” (Freire, 1996). A autonomia do professor é intrínseca à sua profissão e um fator essencial à democratização da escola e do exercício das práticas pedagógicas, tornando-se então necessário rever, assim, as orientações tecnocráticas, que transformam os professores em "funcionários do sistema” (Lima, 2000, p.98), enquadrando suas ações em currículos, orientações pedagógicas e em avaliações já determinadas pelos dirigentes burocráticos.

O professor é um ser político por essência, seja na sua vida pessoal e principalmente na escola, na qual toma decisões que viabilizarão o processo de ensino aprendizagem, reforçando a atual situação ou buscando a transformação social.

Para Paulo Freire, o primeiro passo é encarar a educação como um ato político, pois o trabalho educativo exige opção política.

Se, ao contrário, conscientes das dimensões políticas, cívicas e éticas que marcam indelevelmente as práticas pedagógicas, a interação na sala de aula, a gestão curricular e a programação didática, os modelos de avaliação, a organização do trabalho pedagógico, os modos de gestão escolar, etc., os atores escolares mais dificilmente deixarão de se assumir como atores político-pedagógicos; e por essa via poderão mais facilmente abrir-se à reflexão, ao debate e à ação com outros autores (tradicionalmente representados como externos à escola), com outros saberes e poderes, cruzando-se com novos parceiros institucionais, com organizações comunitárias, movimentos sociais, etc. (Lima, 2000, p.41) 
Nesse sentido, a democratização da educação se apresenta como uma ferramenta que ajuda a rever as posturas burocráticas nas ações educacionais e a sair do isolamento em que esteve a educação, negando a participação da família e da comunidade para que a escola pudesse, assim, estar isenta dos problemas da sociedade. Hoje se faz necessário pensar a escola no contexto social em que vivemos, para que ela possa ajudar a negar a discriminação e a exclusão social, dialogando também com os movimentos sociais. Sendo assim, não podemos pensar em uma escola democrática sem a participação efetiva de outros setores da sociedade, isto é, a participação na gestão escolar não se limita ao envolvimento de professores, alunos e funcionários, mas de uma abertura à comunidade em que está inserida.

A descentralização e a autonomia são dois pressupostos para que a gestão democrática na educação seja efetivada, e assim, possa abrir seus portões para a comunidade local. Esse poder que as escolas conquistam com sua autonomia será redistribuído, pois no processo de participação, o poder passa a ser coletivo e não mais individual, seja o do diretor ou o do professor em sala de aula. O diálogo passa a ser peça fundamental, pois as decisões passarão a ser coletivas.

A autonomia na escola pública pressupõe a elaboração de uma política educacional definida de acordo com a realidade em que está inserida. É importante lembrar que a escola deve ter como referência, a política educacional vigente em nível federal, estadual ou municipal, e a partir daí, ter autonomia para garantir que sua unidade escolar possa elaborar sua política educacional. Dessa forma, a comunidade decide qual será a estratégia fundamental para chegar ao objetivo prioritário que foi elaborado em conjunto e assumido coletivamente. A autonomia visa à capacidade de gerir com participação cidadã, tornando a escola o local de decidir políticas educacionais relacionadas com a sua realidade.

A Lei de Diretrizes e Bases da Educação Nacional - Lei nº. 9394/96, em seu artigo 14, faz referência à gestão democrática e à autonomia da escola, caracterizando o envolvimento de professores e da participação da comunidade local na elaboração do projeto pedagógico em instâncias como o Conselho de Escola ou equivalentes.

Destaca-se o que Gohn diz sobre os órgãos de gestão democrática da escola:

No interior das unidades escolares temos ainda o Conselho de Escola, o Conselho de Classe e de Série e o Grêmio dos Estudantes; (...) são canais de participação importantes na mobilização da comunidade educativos para a melhoria da escola e da qualidade de vida do bairro. O Conselho de Escola incorpora representantes da comunidade local. Juntos, direção da escola, grêmio dos estudantes e conselho das escolas podem realizar: 
investigações sobre a realidade escolar e propor soluções; implantação de centros de estudos; organização de salas de leitura, sala de artes e outras atividades na área da cultura, esporte e lazer nas escolas, assim como utilização de dependências da escola pela comunidade local. A articulação/direção/grêmio e conselho pode gerar uma gestão participativa que conheça melhor a própria comunidade escolar, seus saberes e práticas. Juntos podem fazer uma etnografia da escola e elaborar um projeto político-pedagógico renovado. (Gohn, 2001, p.1034)

O que se percebe atualmente nas escolas públicas, é a não apropriação desses espaços de ações participativas pelos agentes educacionais e pela população do bairro. Esses Conselhos deveriam colaborar com a escola fazendo com que os alunos pudessem perceber a real importância do processo democrático em suas vidas. O que se verifica é que em muitas redes de ensino municipal há uma demora para a implantação da gestão democrática, e naquelas em que a mesma está sendo implantada, há certa resistência à perda de autoridade por parte dos dirigentes educacionais.

Ao destacar a importância da gestão democrática na educação, ressaltamos que ela faz o exercício da busca do consenso. A participação nos Conselhos vai permitir a convivência e a manifestação dos conflitos, pois se estará lidando com diferentes pensamentos e com classes sociais diferenciadas, fazendo assim com que a democracia possa se fortalecer em nosso país.

Paro (2005), ao falar em gestão democrática, refere-se ao fato de ser necessário dar condições para que as camadas populares participem da vida da escola. O autor também caracteriza essa participação.

Aceitando-se que a gestão democrática, deve implicar necessariamente a participação da comunidade, parece faltar ainda uma maior precisão do conceito de participação. A esse respeito, quando uso esse termo, estou preocupado, no limite, com a participação nas decisões. Isto não elimina, obviamente, a participação na execução; mas também não a tem como fim e sim como meio, quando necessário, para a participação propriamente dita, que é a partilha do poder, a participação na tomada de decisões. É importante ter sempre presente este espaço para que não se tome a participação na execução como fim em si mesmo, quer como sucedâneo da participação nas decisões, quer como maneira de escamotear a ausência desta última no processo.(Paro,2005,p.16).

A participação na escola pública requer a divisão de poder e a tomada de decisões coletivas para que a escola deixe de ser autoritária e passe a entender a prática democrática como um princípio da educação, aprendendo a ser democrático exercitando a participação. 
A participação da comunidade na escola,como todo o processo democrático, é um caminho que se faz ao caminhar, o que não elimina a necessidade de se refletir previamente a respeito dos obstáculos e potencialidades que a realidade apresenta para a ação. (Paro, 2005, 17)

Como já foi dito as pessoas aprendem a participar realizando esse ato, mas o caráter autoritário de nossa sociedade limita essa participação, pois está enraizada a relação de submissão, inviabilizando a prática da democracia e da participação. Sendo assim, como nos alerta Paro, mecanismos de participação como as Associações de Pais e Mestres (APMs) e os Conselho de Escola se tornam figurativos exercendo funções burocráticas.

Diante de tudo isso, e tendo em conta que a participação democrática não se dá espontaneamente, sendo antes um processo histórico de construção coletiva, coloca-se a necessidade de se preverem mecanismos institucionais que não apenas viabilizem, mas também incentivem práticas participativas dentro da escola pública. Isso parece tanto mais necessário quanto mais considerarmos nossa sociedade, com tradição de autoritarismo, de poder altamente concentrado e de exclusão de divergência nas discussões e decisões. (Paro, 2005, p. 46)

O que queremos ressaltar é a importância dos mecanismos de participação popular nas escolas públicas. Os pais devem fiscalizar e ajudar no funcionamento da escola, tornando-se também responsáveis pela instituição e também pelo processo pedagógico e não apenas executores de atividades, pois o que destacamos nesse processo é também a aprendizagem que um momento de debate pode ocasionar, bem como o direito de participar e exercer a cidadania. 


\section{A IMPLANTAÇÃO DA GESTÃO DEMOCRÁTICA NA REDE MUNICIPAL DE EDUCAÇÃO DE ARARAQUARA.}

A gestão democrática implica entender o processo de interação social. Observa-se que o papel da escola tem como fundamento ser instrumento de democratização e, sendo assim, como nos orienta Freire (1996), a educação, para uma participação ativa, deve começar na escola. Vale ressaltar que a escola deve estar aberta para buscar uma interligação com a sociedade, com os movimentos sociais, e assim, viabilizar a gestão democrática, como um princípio para o cidadão.

Considerando, portanto, o fortalecimento da gestão democrática, o Governo municipal se propôs a realizar uma Conferência Municipal de Educação que envolvesse professores, funcionários, pais, alunos, as entidades educacionais e a sociedade civil, de modo geral, para, a partir dela, formular as diretrizes para a educação no município de Araraquara.

No município de Araraquara existem 70 escolas públicas, sendo 32 escolas públicas de educação infantil. A cidade conta também com 27 escolas estaduais, com atendimento de ensino fundamental e médio, e 11 escolas de ensino fundamental municipais. Existem também 46 escolas privadas. Destas, 28 são de educação infantil, 17 com atendimento no ensino fundamental, 12 no ensino médio, 3 com atendimento em educação especial e 3 com atendimento em educação de jovens e adultos. Existe uma Escola Técnica Estadual, de caráter profissionalizante, vinculada à Secretária de Estado da Ciência e Tecnologia. No que diz respeito ao ensino superior, como já foi mencionado, há um Campus da Universidade Estadual Paulista (UNESP) e três instituições de ensino superior privado: UNIARA, UNIP e Faculdades Integradas Logatti.

Existem 1804 professores na educação básica pública, sendo 774 da rede municipal e 1.030 da rede estadual. Em relação aos alunos, pelo Censo Escolar de 2005 (site: Prefeitura Municipal de Araraquara), a rede municipal tem 15.496 e a rede estadual conta com 21.383 alunos. 


\section{A CONFERÊNCIA MUNICIPAL DE EDUCAÇÃO DE ARARAQUARA}

A Conferência Municipal de Educação, que ocorreu em junho de 2001, teve como tema a "Educação para a Cidadania”, com o objetivo geral de "promover amplo debate e mobilização social para a construção coletiva das diretrizes para a Educação no Município de Araraquara” (Araraquara, 2001). Foi uma grande iniciativa para a construção de uma gestão democrática na educação, pois propiciou a todos os envolvidos, a participação na elaboração das diretrizes educacionais, nos mais diversos temas, tornando-se um espaço de discussão democrática sobre os rumos da educação no município de Araraquara. Vale ressaltar que essa realização era uma proposta do Programa de Governo da Administração Municipal que dizia: “Organizar já nos primeiros meses de governo, uma Conferência Municipal de Educação, envolvendo alunos, pais, professores e funcionários, para definir as diretrizes para a educação no município”.

Preparando a Conferência, que ocorreu no mês de abril daquele mesmo ano, deu-se a instalação de um Fórum Municipal de Educação, que teve como objetivo ser um "espaço permanente de debate de questões educacionais, visando a melhoria da qualidade de ensino no Município de Araraquara e a construção de uma educação voltada para a cidadania”. (Araraquara, 2001).

Participaram desse Fórum Municipal de Educação, 296 (duzentos e noventa e seis) pessoas, divididas em grupos para discutirem e formularem propostas que foram debatidas na Conferência Municipal de Educação. Estes grupos de trabalho foram organizados visando ser um espaço de discussão que preparassem, de forma democrática, a Conferência Municipal de Educação. Os grupos foram formados de acordo com os temas abaixo:

- Gestão Democrática da Educação

- Financiamento da Educação

- Formação de Educadores

- Plano de Carreira e Estatuto do Magistério

- Escola Inclusiva

- Educação Infantil

- Ensino Fundamental

- Ensino Médio 
- Movimento de Alfabetização (MOVA) e Educação de Jovens e Adultos (EJA)

- Educação Complementar, Ações Complementares e Projetos Especiais

- Temas Transversais x Intervenções Pontuais

- Escola e Violência

- Escola Rural

- Alternativas ao Trabalho Infantil

- Arte-Educação

Com a implementação de um Fórum de discussões que aglutinou diversos segmentos da educação do município para a organização da Conferência Municipal de Educação, percebeu-se a disposição do Governo do Município em democratizar a educação, abrindo espaços para a participação no que se refere à formulação de políticas públicas e de metas para o município. Neste sentido, terá ênfase um dos eixos desta Conferência denominada “Gestão Democrática”, que é o foco do nosso trabalho.

\section{DIRETRIZES PARA A GESTÃO DEMOCRÁTICA NA EDUCAÇÃO MUNICIPAL DE ARARAQUARA}

Como foi dito anteriormente, o Fórum Municipal de Educação preparou e debateu os temas para a Conferência Municipal de Educação. Desta Conferência participaram 364 (trezentos e sessenta e quatro) delegados inscritos indicados pelas instituições de ensino e também os membros do Fórum. Estes se envolveram nas discussões de todos os grupos formados no Fórum Municipal. O grupo de trabalho sobre gestão democrática, estabelecido no Fórum, contou com o envolvimento de 15 pessoas, entre professores, diretores, funcionários da rede municipal, pais de alunos e estudante universitário, que elaboraram propostas para serem debatidas na Conferência Municipal.

Este grupo discutiu temas referentes ao processo de gestão democrática a ser implantado pela Secretaria Municipal de Educação: Conselho Municipal de Educação, Conselhos de Escola, grêmios estudantis e eleição de diretores e coordenadores de unidades escolares. O grupo encarregado do tema Gestão Democrática pautou seus 
trabalhos em discussões e análises de propostas para elaboração do Projeto de Lei que instituiu o Conselho de Escola nas unidades de educação municipal, bem como a proposta de um Regimento Interno para o funcionamento dos mesmos.

O documento final da Conferência Municipal de Educação de Araraquara ressalta que:

\begin{abstract}
A gestão democrática tem por finalidade possibilitar à escola um maior grau de autonomia garantindo o pluralismo de idéias; uma concepção pedagógica que assegure uma escola efetivamente pública e transformadora, voltada para o interesse das classes populares, capaz de redimensionar práticas tradicionais instituídas de caráter elitista, classificatório e seletivo. (Araraquara, 2001, p.58).
\end{abstract}

Nesse Grupo também foram debatidas propostas para a reformulação e ampliação do Conselho Municipal de Educação, para que este fosse mais representativo, no âmbito da sociedade civil, e garantido o seu caráter de órgão deliberativo da Secretaria Municipal de Educação. Houve a alteração da Lei que havia instituído o Conselho Municipal de Educação, modificando-se sua composição que passou de 12 membros para 33 membros, contemplando-se os vários segmentos da sociedade civil. Os membros do novo Conselho Municipal de Educação podem ser verificados no anexo A, ao final desse trabalho.

Foi apresentado na Conferência, o Projeto de Lei que instituiu os Conselhos de Escolas nas unidades escolares do município. Essa lei foi enviada à Câmara de Vereadores e aprovada no dia 25 de março de 2002 (a Lei consta do anexo B). Os Conselhos de Escola passaram a constituir um espaço de decisões com o objetivo de democratizar as relações de poder no interior da escola e passaram a ser o órgão máximo de decisões da unidade escolar. A natureza desse conselho é deliberativa, consultiva, normativa e fiscalizadora e a composição de seus membros é paritária: 50\% para representantes da comunidade escolar e local e 50\% para o Poder Público (funcionários, professores, direção), tendo ficado estabelecido, reuniões mensais.

Para os Grêmios Livres, a Conferência garantiu a formação de Entidade representativa dos estudantes, considerando um espaço de organização, de discussão, elaboração de projetos pelos estudantes para que estes possam desenvolver o senso crítico e participativo. A proposta do grupo de Gestão Democrática era de implementar os grêmios estudantis já no segundo semestre de 2001, tendo como apoio, os Conselhos de 
Escola, os professores e a direção das escolas para a elaboração de um Estatuto, bem como uma divulgação entre os alunos, coordenada pela Secretaria de Educação do município.

Outro tema trabalhado pelo Grupo de Gestão Democrática é a escolha do diretor e coordenador pedagógico. O Grupo havia discutido e encaminhou como proposta que a função de diretor e de coordenador pedagógico fosse preenchida por meio de eleição. Foi discutido na Conferência e a Assembléia decidiu que a função de Professor Coordenador seria ocupada por meio de eleição, pelos seus pares, e homologada pelo Conselho de Escola e a função de Diretor de Escola, continuaria sendo feita através de concurso público de títulos e provas.

Sobre esse assunto vale fazer alguns comentários. Segundo Paro (1996) o principal argumento utilizado para a realização de concursos para Diretor de Escola é da moralidade pública diante da escolha de funcionários para cargos do Estado e a capacidade técnica desses ocupantes. Outro argumento, é impedir o clientelismo utilizado na relação de nomeação política para ocupar esse cargo.

Ressalta a busca pelo tratamento igualitário aos candidatos, pois o concurso é encarado como uma forma democrática de escolha por não haver favorecimentos pessoais. Paro (1996) nos lembra que o diretor concursado quando assume o cargo, ele escolhe a escola, mas a comunidade escolar e o bairro não o escolheram, passando assim a ser democrático apenas de um lado, pois o processo de escolha garante a igualdade de oportunidade por meio de provas e títulos para que se atenda ao caráter técnico (formação e tempo de serviço no magistério).

Podemos verificar que essa conduta para a escolha do Diretor de Escola é realizada na rede estadual de São Paulo, sendo assim, os membros da Conferência Municipal de Educação de Araraquara assimilaram essa prática já enraizada no Estado, não refletindo sobre as vantagens democráticas de uma eleição de Diretor de Escola.

Pode-se destacar, conforme estudos realizados, que, em redes que optaram pela eleição, houve maior aproximação entre o Diretor de Escola e os professores, os funcionários, os alunos e os pais, quebrando a visão autoritária existente nessa relação. Possibilitou, também, maior diálogo entre as partes e posturas mais democráticas em relação ao Conselho de Escola e aos grêmios estudantis.

Se a Conferência Municipal de Educação tivesse aprovado o processo de escolha de Diretores de Escolas, através de eleição, a democratização da gestão pública seria 
ampliada, pois, a eleição seria mais um canal de participação para o crescimento da conscientização política e da cidadania dos moradores locais.

Outro momento de mobilização de caráter democrático na área da Educação foi a elaboração do Plano Municipal de Educação, que constituiu o documento base da II Conferência Municipal de Educação de 2004. Para a realização dessa Conferência, foi realizado, em abril de 2003, um encontro do Fórum Municipal de Educação, convocado pela Secretaria de Educação, conjuntamente com o Conselho Municipal de Educação, visando retomar os grupos de trabalho para as discussões sobre o Plano Municipal de Educação. Deste trabalho resultou o documento que foi apresentado à II Conferência de Educação, que se realizou no mês de março de 2004. Participaram destas discussões a Secretaria Municipal de Educação, o Conselho Municipal de Educação, representantes do Governo Municipal, Diretoria Regional de Ensino, organizações não-governamentais, escolas estaduais, municipais e privadas, Instituições Universitárias, especialistas em educação e todos os interessados nas questões educacionais.

Este relato mostra como foi importante, ou seja, como foi um passo fundamental para a implementação de ações que viessem à distribuição de poder em uma Instituição que se tornará reprodutora dos interesses da classe dominante. Com o Fórum Municipal e a Conferência Municipal de Educação ocorreram envolvimentos daquelas pessoas que faziam parte do processo educacional,levando a que eles participassem das deliberações. Cada tema desenvolvido pelo grupo de trabalho passou a ter maior legitimidade, quando se tornaram ações no interior da escola, mudando assim o caráter autoritário da escola pública.

A democracia participativa é fundamental para uma mudança social e cultural. A escola pública é um espaço no qual a comunidade pode exercitar essa participação, fazendo dela um mecanismo de mudança social, tornando-se espaços de educação e de participação cidadã, nos quais as escolas serão colaboradoras para a formação de uma administração pública democrática. 


\section{GESTÃO DEMOCRÁTICA NA SAÚDE E OS CONSELHOS GESTORES DE UNIDADES}

Os Conselhos de Saúde, sejam nacional, estaduais ou municipais, foram criados por pressão popular a partir da Constituição Federal de 1988. A característica desses Conselhos é ter representantes eleitos de todos os segmentos da sociedade, sejam usuários do sistema ou prestadores de serviços. Outra característica é a sua paridade. Metade dos seus participantes pertence a entidades que representam os usuários e a outra metade de funcionários do sistema de saúde. Os Conselhos de Saúde têm, também, no seu caráter deliberativo a expressão de uma importante conquista para a participação da sociedade. $\mathrm{O}$ objetivo maior dos Conselhos é a questão do controle social, no qual o cidadão possa auxiliar a gestão pública para que ofereça um melhor atendimento à população.

No município de Araraquara existe o Conselho Municipal de Saúde, que foi instituído por lei municipal, que gerencia os recursos financeiros e os atendimentos nesta área. O que podemos perceber, com relação à participação da população, é que esse Conselho tem uma representação muito elitista. Ele contempla as entidades da sociedade civis, mas seus representantes não correspondem às expectativas de envolvimento dos seus representados. São pessoas que se auto-representam, não dando um retorno àqueles aos quais representam.

A grande novidade para a Cidade, no que diz respeito à participação da comunidade no gerenciamento da área da saúde, foi a criação do Conselho Gestor das Unidades Básicas de Atendimento à Saúde. Estes foram criados com a finalidade de ampliar a participação da população na formulação de políticas públicas de saúde.

No município existem 21 Unidades Básicas de Saúde (UBS). Em cada uma delas, foram constituídos Conselhos Gestores, no ano de 2001. Sua composição é estabelecida pela paridade, isto é, 50\% de representantes da população e 50\% de representantes de funcionários das Unidades, reunindo-se mensalmente. Foram eleitos 401 Conselheiros e Conselheiras. Este conselho foi constituído pela Lei Municipal n 5.655/01 (vide anexo D) e tem por finalidade "estimular a participação popular na definição de diretrizes para a saúde do município e para melhoria da qualidade de vida da população”.

Sendo assim, a função do Conselho Gestor é acompanhar, avaliar e fiscalizar as atividades das Unidades, participando das decisões sobre sua organização interna, além de avaliar se a população está satisfeita com os serviços prestados. Uma das mobilizações 
mais significativas desses Conselhos foi a reivindicação para a participação no Conselho Municipal de Saúde que culminou com a realização da VI Conferência Municipal de Saúde em dezembro de 2005, e na qual, um dos eixos temáticos definidos foi o Controle Social, tendo como um de seus sub-produtos a modificação da composição do Conselho Municipal de Saúde, que passou a contar, também, com representantes da população dos Conselhos Gestores das Unidades Básicas de Saúde.

\section{A EXPERIÊNCIA DE ORÇAMENTO PARTICIPATIVO DE ARARAQUARA}

Em seu Plano de Governo, a Frente Democrática e Popular expôs a sua proposta de atuação para as diversas áreas do Município. Essa Gestão adotou, como primeiro passo para garantir à participação popular, a implantação do Orçamento Participativo (OP), com base legal na Constituição Federal de 1988 e também na Lei Orgânica do Município de Araraquara que estabelecem como princípio, "uma democracia representativa e participativa”.

\section{A ESTRUTURA E O FUNCIONAMENTO DO ORÇAMENTO PARTICIPATIVO}

O OP de Araraquara é viabilizado pela Coordenadoria de Participação Popular (CPP), que estava subordinada, no organograma de estrutura funcional da Prefeitura (2001 a 2004), ao Gabinete do Prefeito. Para colocar em prática o processo do OP e garantir um processo decisório descentralizado, o município foi dividido em 8 regiões. São 7 regiões urbanas e 1 rural, região esta que abrange três assentamentos e pequenos produtores rurais. Essa estrutura se inspirou no processo de OP da cidade de Caxias do Sul (RS), bem como todo o processo de execução.

No início do processo houve necessidade de explicar para a sociedade o que iria acontecer na Cidade com essa nova maneira de administrar. Então, foram mapeados e convocados grupos de representação social existentes na cidade como sindicatos, abrigos 
de crianças, Lions, Rotarys, associações de moradores, igrejas de diversas denominações e centros espíritas. Nessa primeira ação da CPP, estiveram presentes cerca de 300 pessoas, mas o resultado foi apenas informativo, pois esses grupos não se sentiram comprometidos com a proposta.

O princípio que rege a participação no OP de Araraquara é que deve ser uma participação aberta a todo o cidadão, sem nenhum privilégio a qualquer entidade ou organização. O que é valorizado é o morador do bairro. É ele quem toma a palavra, expõe suas reivindicações, vota a prioridade e elege os Delegados. A representação de Delegados se dá também por manifestação espontânea no momento da plenária ${ }^{5}$. Neste sentido, o que se percebe é que o OP se torna um novo espaço de participação e de conscientização do cidadão sem a intermediação de Instituições, que muitas vezes podem estar viciadas pelo clientelismo marcante na cidade, e também abre espaço para novas formas de organização, na medida em que o cidadão vai tomando consciência de sua capacidade de mobilização.

Nesse sentido, a Equipe da CPP fez várias reuniões em bairros da Cidade para apresentar a proposta de OP para os moradores e explicar como seria “dividido” o recurso financeiro que seria destinado para investimentos na cidade. A essa etapa deu-se o nome de reuniões explicativas. Para que isso ocorresse, foram utilizados mecanismos de comunicação como carro de som, convites a entidades de bairros e divulgação por meio de panfletos nas escolas. É necessário destacar também a importância dos equipamentos públicos localizados nos bairros para acolher a população participante das reuniões.

\footnotetext{
${ }^{5} \mathrm{O}$ processo detalhado será explicado mais adiante.
} 


\section{AS PLENÁRIAS DO ORÇAMENTO PARTICIPATIVO}

Como já foi dito, o município de Araraquara foi dividido em 8 regiões que tiveram como critério a proximidade entre bairros e acidentes geográficos, como linha férrea, rios e córregos. O processo se estabelece pela realização de plenárias regionais e sub-regionais.

\section{O FUNCIONAMENTO}

Nos anos de 2001 e 2002, o processo iniciou-se com um Seminário Aberto, que tinha como objetivo ser um momento de abertura do processo e explicação das regras, com aprovação do Regimento Interno pelos presentes. No primeiro ano, também foi submetida para apreciação da Assembléia, a divisão da cidade em 8 regiões. No ano de 2003 e 2004, esta etapa foi suprimida e o Regimento Interno passou a ser aprovado pelos conselheiros do OP.

As Plenárias Regionais estavam divididas em duas partes nos anos de 2001 a 2003. Na Plenária Regional I, eram apresentadas as contas da Prefeitura e começavam as discussões sobre as prioridades a serem elencadas até o final do processo. Nos primeiros anos, por conta da participação do Prefeito e pelo espaço que estava sendo proporcionado, os participantes não se limitavam às questões dos investimentos, discutiam também sobre o funcionamento da cidade e questões de manutenção. Ainda nesta fase, eram eleitos os Delegados, que seriam os representantes do bairro que fariam a "ponte” entre a população e a Prefeitura. A eleição desses Delegados se dá na proporção de 1 para 10 pessoas presentes do bairro, ou seja, cada 10 participantes elegem 1 delegado, ficando garantida a representação mínima de 1 delegado por bairro presente, conforme o Regimento Interno.

A etapa seguinte criada pela CPP, que pode ser chamada de etapa intermediária, é a sub-divisão das regiões em conjunto de bairros em números menores. Essa reunião, que é também organizada e divulgada pelos agentes da Prefeitura, mais o apoio dos Delegados, tem como finalidade proporcionar ao cidadão a discussão com mais pessoas de localidade mais próxima elencando também prioridades e elegendo mais delegados, caso a participação nessa reunião for uma proporção maior que na Plenária Regional, conforme critério estabelecido pelo Regimento Interno do ano. 
Para finalizar o processo de discussão das prioridades, são realizadas as Plenárias Regionais II, onde a população elege 3 prioridades hierarquizadas por região.

Ao processo do OP, a partir de 2002, foram inseridas também as plenárias temáticas. Cabe aqui ressaltar que o OP é um processo dinâmico e têm características próprias em cada lugar em que é realizado. Por isso, em Araraquara, as Plenárias Temáticas são diferentes das de Porto Alegre, por exemplo, em que os temas não são por segmentos sociais, mas por assuntos relacionados ao funcionamento da administração. As Plenárias Temáticas em Araraquara têm como objetivo discutir políticas públicas para setores da população que são discriminados pelo processo histórico brasileiro. Esses “segmentos” eram compostas por: portadores de deficiência, os afro-descendentes, as mulheres, os jovens e os idosos. Nas reuniões, esses segmentos apresentam projetos para serem discutidos e votados pela Assembléia presente.

A diferença dessas Plenárias Temáticas para as Plenárias de Bairro é que os participantes comparecem às reuniões organizados em grupos, que geralmente já trabalham em algum tipo de organização e que perceberam que o OP é um espaço de discussão sobre os recursos orçamentários para a execução das políticas públicas.

Uma sexta plenária temática também é realizada. Ela não abrange “segmentos” de forma específica, mas discute a Cidade de modo geral, isto é, elementos que não foram levantados nas Plenárias de Bairros, mas que são de interesse de toda a Cidade. Essa plenária é denominada Plenária da Cidade e prioriza investimentos nas áreas de desenvolvimento urbano e econômico. O que podemos perceber quanto à participação desta plenária é que segmentos como Associações de Arquitetos, Engenheiros, Comerciários, Industriais não sentem que este é um espaço importante de debate sobre a cidade. Quem participa são os cidadãos que de alguma forma participam de Programas da Prefeitura, ou estão se organizando em cooperativas e que têm a necessidade de disputar recursos financeiros. Nessas Plenárias Temáticas também são eleitos Delegados e definidos Conselheiros.

Vejamos o quadro 1 que estabelecido o cronograma para a realização do processo do $\mathrm{OP}^{6}$.

\footnotetext{
${ }^{6}$ Cronograma apresentado nas reuniões do OP para explicação do processo.
} 


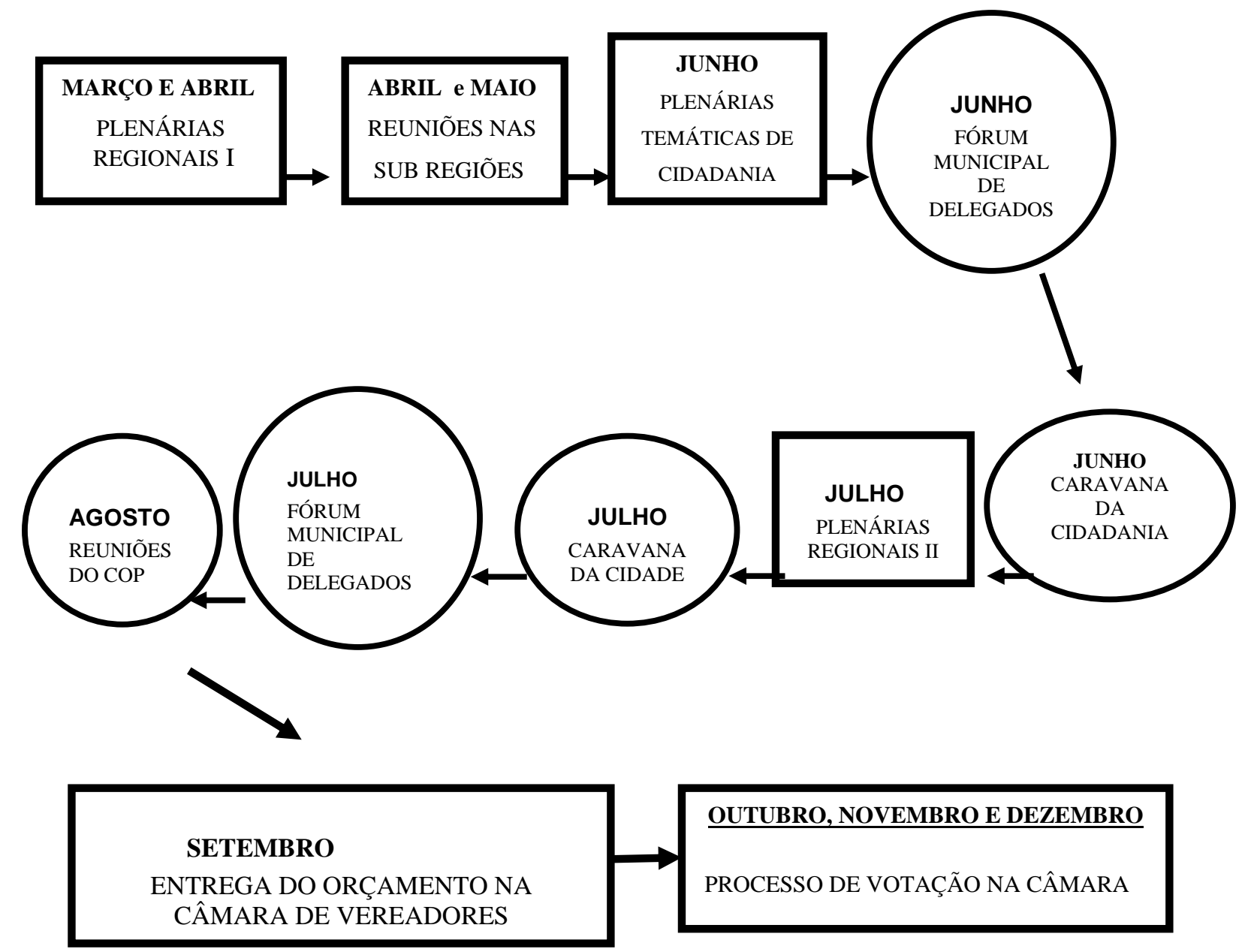

Fonte: Prefeitura de Araraquara

\section{ANALISANDO A PARTICIPAÇÃO NAS PLENÁRIAS DO OP}

Os gráficos e tabelas são resultados de informações coletadas no momento da inscrição dos participantes nas reuniões do OP. Nessa inscrição, as pessoas que participam, respondem um questionário constando: nome, endereço, cor/raça, sexo, se é portador de deficiência, grau de escolaridade e também se é a primeira vez que participa da reunião. 
Quem realiza essa inscrição é a própria Equipe da CPP. Esses dados foram fornecidos pela Prefeitura de Araraquara para mostrar a participação da população desse processo.

Vejamos o gráfico 1 que mostra o número de participantes nos três anos de OP (2001 a 2003).

\section{Gráfico 1 - Participação total nas regiões}

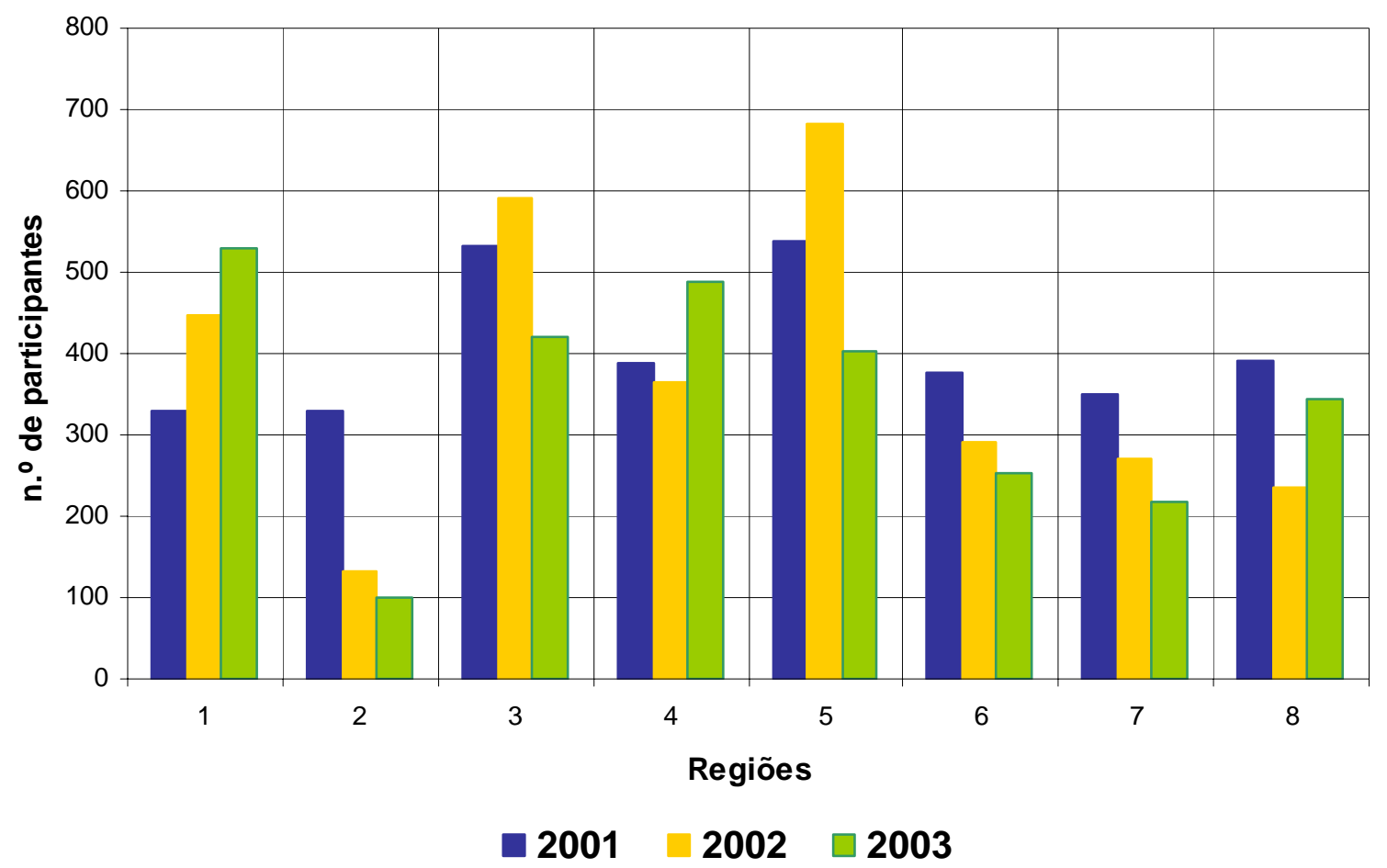

Fonte: Prefeitura de Araraquara

No primeiro ano de implantação do OP, verificamos que foi o ano de maior participação, pois era o ano da novidade e da expectativa de um Governo Popular. Era o momento de se discutir tudo. Todos os problemas que angustiavam a população eram colocados na Assembléia. Havia uma necessidade de falar com o Prefeito e de lhe mostrar a situação que existia em cada bairro. A necessidade era de resolução imediata e as falas eram muitas vezes particularizadas.

No segundo ano, o gráfico 1 mostra um aumento na participação nas regiões 1, 3 e 5, que são regiões onde se localizam grandes demandas em infra-estrutura. Já nas outras regiões, constata-se uma diminuição na participação. Uma explicação possível sobre essa diminuição é a da não realização, até a época das reuniões do OP, das obras votadas no ano anterior caracterizando, talvez, uma descrença no processo do OP e a necessidade imediata 
da população de ver seus problemas resolvidos em curto prazo. Essa hipótese aparece de maneira objetiva nas entrevistas e também verificamos em pesquisa realizada em município do Estado do Paraná pela pesquisadora Gouveia (2002).

- Vejamos o que diz Pont a respeito da participação inicial das pessoas nesse processo:

Disputar a renda da cidade abertamente, democraticamente, estabelece, novos parâmetros igualmente para a discussão e a superação do egoísmo e da solidariedade, uma consciência mais aguda entre a cidadania. As pessoas aparecem, a primeira vez, para resolver o problema da frente da sua casa - nem é da rua. Em alguns anos, já se preocupam com a rua, com o bairro, com a cidade, com políticas setoriais. Isso gera uma outra visão, de enfrentamento contra o individualismo e o egoísmo ensinados pelo capitalismo. (Pont, 2000, p. 81).

Pode-se analisar a participação no sentido em que Pont nos coloca. As pessoas participam do processo inicialmente para resolver os seus problemas, mas com o passar do tempo, com o envolvimento do processo, verificamos que o OP estabelece uma relação entre as pessoas e a cidade, fazendo com que os cidadãos se sintam sujeitos do processo e comecem a participar com uma visão de solidariedade e de cidade. Quando detalharmos as entrevistas isso poderá ficar mais claro.

As tabelas 1, 2 e 3 detalham os números da participação: 
TABELA 1- Participação por Reuniões do OP

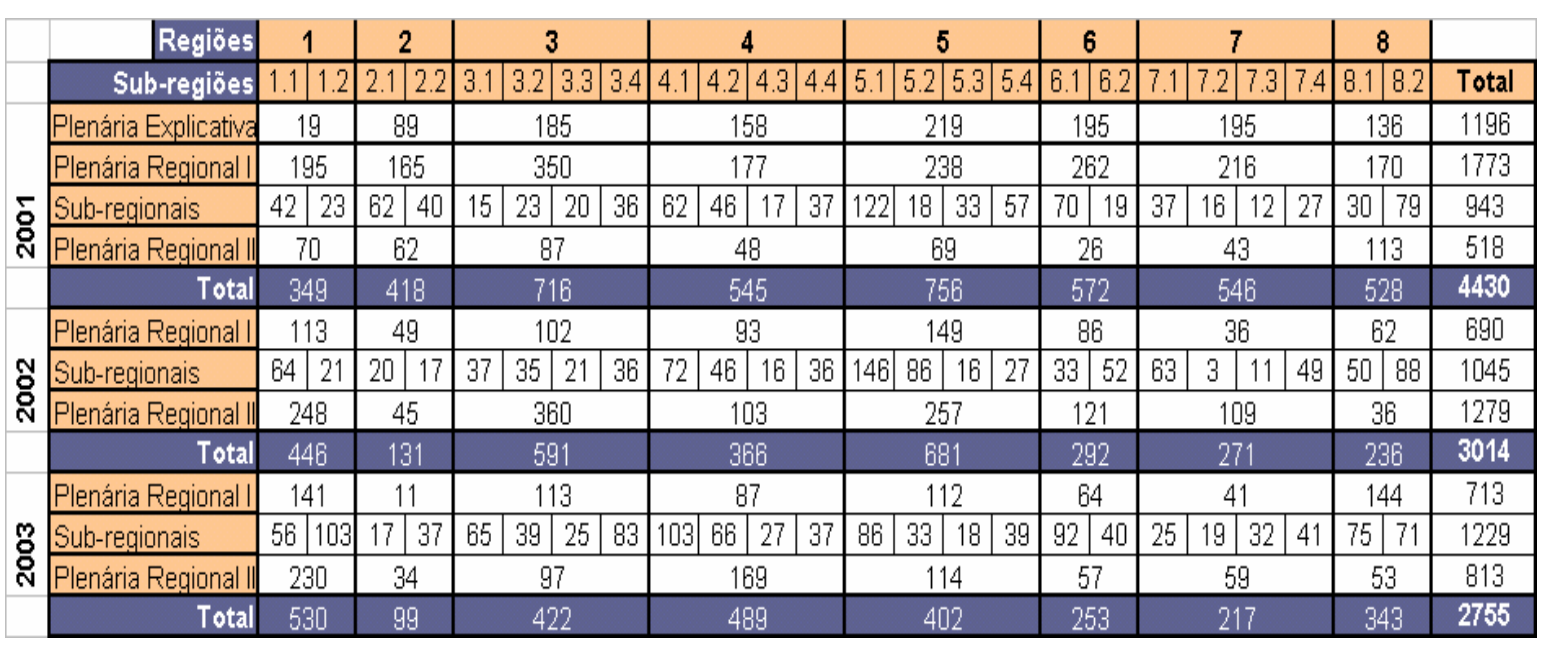

Fonte: Prefeitura de Araraquara

Na tabela 1 verifica-se uma grande participação nas Plenárias Regionais I no ano de 2001. Esse ano foi o da novidade e também de conhecimento do OP pela população. A partir dos anos seguintes o que se observa é uma diminuição da participação nessa Plenária e um aumento na etapa das sub-regiões e também em alguns casos das Plenárias Regionais II.

TABELA 2 - Participação Total do OP

\begin{tabular}{|c|c|c|c|c|c|c|c|c|c|c|}
\hline Regiöes & 1 & 2 & 3 & 4 & 5 & 6 & 1 & 8 & PI. Tem. & Total \\
\hline 2001 & 349 & 418 & 716 & 545 & 756 & 572 & 546 & 528 & 0 & 4430 \\
\hline 2002 & 446 & 131 & 591 & 366 & 601 & 292 & 271 & 236 & 578 & 3592 \\
\hline 2003 & 530 & 99 & 422 & 489 & 402 & 253 & 217 & 343 & 542 & 3297 \\
\hline 40 & & & & & & & & & & 11319 \\
\hline
\end{tabular}

Fonte: Prefeitura de Araraquara

A diferença numérica do ano de 2001 para os outros anos é significativa e deve-se levar em conta a etapa das reuniões explicativas, que só ocorreram no primeiro ano e que foram contabilizadas no total da participação. 
Analisando esses dados é possível afirmar que, talvez porque a população começa a entender o processo do OP, ela se mobiliza com maior intensidade para participar da Plenária Regional II (2002 e 2003), que é a Plenária decisiva para eleição das prioridades e dos conselheiros.

O crescimento da participação nas reuniões do OP nas sub-regiões, provavelmente, se dá pelo fato de esta etapa ocorrer mais próxima da população, pois é formada por quantidade menor de bairros, facilitando a locomoção e também a identificação do morador com aquilo que está mais próximo dele.

No ano de 2004, o Conselho do Orçamento Participativo, baseando-se nos dados a cima, elimina a etapa da Plenária Regional I. Essa atitude demonstra que o processo do OP é dinâmico e deve se adaptar às respostas que a população vai dando durante o período. Mas também se questiona essa atitude na medida em que se perde um espaço de debate e discussão entre a população e o poder público.

Na tabela 2, pode-se constatar uma variação na participação nos anos de 2001 a 2003. Algumas regiões apresentam uma diminuição na participação, cuja hipótese mais freqüente é que isso se deu pelo atraso nas obras que foram votadas anteriormente. Esse atraso, frequentemente, faz com que a população sinta um descrédito diante do processo do OP. Para esta análise, pode-se reportar aos estudos de Gouveia (2002, p. 88). Em outros casos, em locais onde foram realizadas as obras e sanadas as urgências, a participação também diminuiu, podendo-se aventar que a mesma seja conseqüência da fragilidade do exercício da cidadania. Em contraposição existem também regiões na cidade que percebem a importância do processo e começam a se organizar de forma mais ativa para a participação, como é o caso da região 1, que apresenta um crescimento nesse período. 
TABELA 3 - Renovação dos Participantes

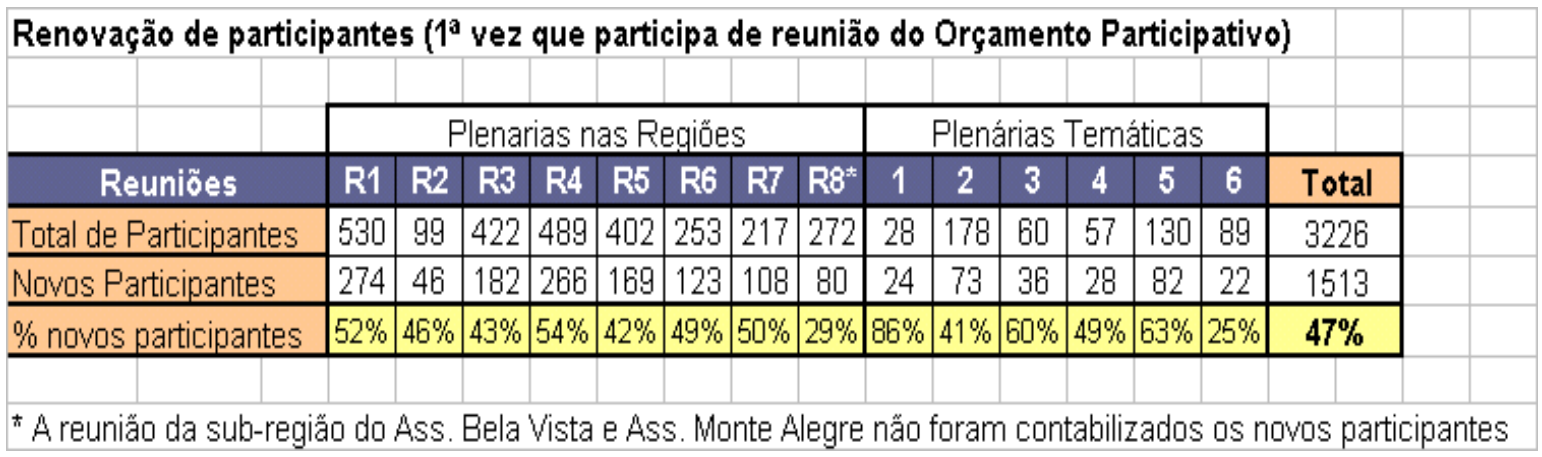

Fonte: Prefeitura de Araraquara

Com relação à renovação de participantes nas reuniões do OP, conforme constante na tabela 3, pode-se observar que os novos participantes chegam a quase a metade do total da participação. Do ponto de vista positivo, pode-se analisar que o OP é um espaço aberto de participação, onde todos podem debater e escolher prioridades e a população começa a perceber que ela tem voz e voto nas questões da cidade e que pode ser agente transformador da sua realidade. Nesse sentido, pode-se citar o trabalho de Genro (1997, p. 28), em relação a essa característica da participação, uma vez que o OP de Araraquara tem características semelhantes.

Por outro lado, com os dados observados na tabela 3 permite-se afirmar que as pessoas que participaram do OP não estão retornando em outros anos. Uma explicação para essa atitude poderia ser que suas demandas já foram atingidas. Nesse sentido, o OP como mecanismo de conscientização política, apresenta dificuldades de, num curto período, fazer com que as pessoas percebam a importância de discutir a cidade, pois a discussão do orçamento é algo que gera expectativas imediatas em um povo que é muito sofrido e que se sente abandonado.

Os gráficos 2 e 3, mostram a comparação do número de participantes dos 4 anos de Orçamento Participativo em Araraquara (2001 a 2004), bem como o desenvolvimento do seu processo de reuniões: 
PARTICIPAÇÃO NO ORÇAMENTO PARTICIPATIVO - 2001 A 2004

Os gráficos 2 e 3 e a tabela 4 mostram a participação entre os anos de 2001 a 2004. Foram registrados em 179 reuniões, 13.863 “participações”, O termo, “participações”, foi escolhido pela Equipe da Prefeitura Municipal para caracterizar que um único participante pode ter participado em várias reuniões.

Gráfico 2 - Participação OP 2001/04

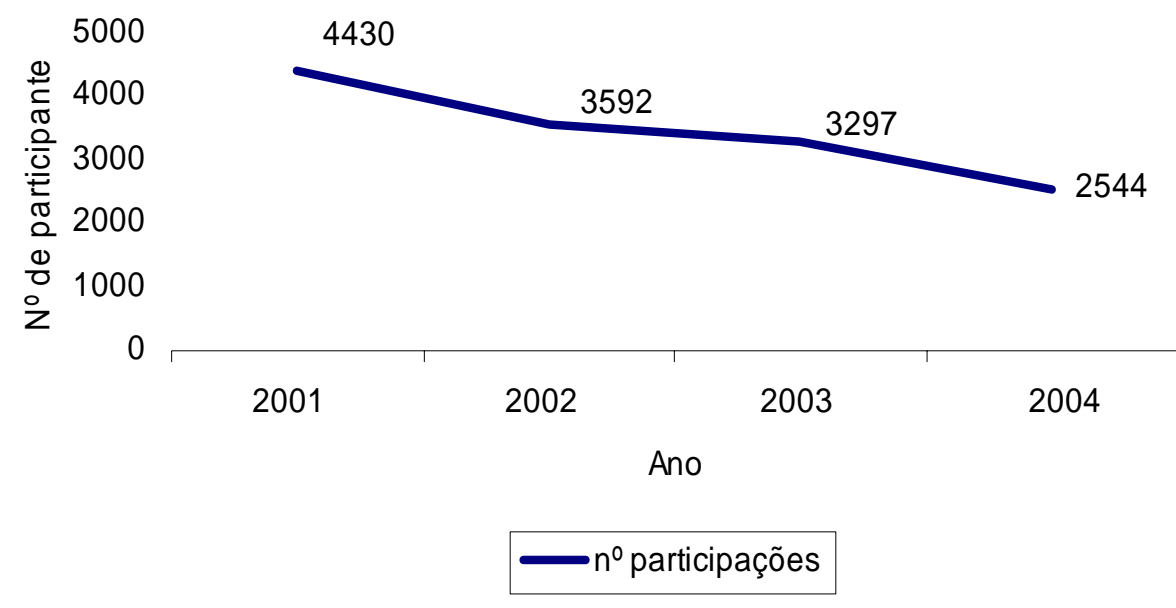

Fonte: Prefeitura de Araraquara

Gráfico 3 - Média de participantes por reunião/ano

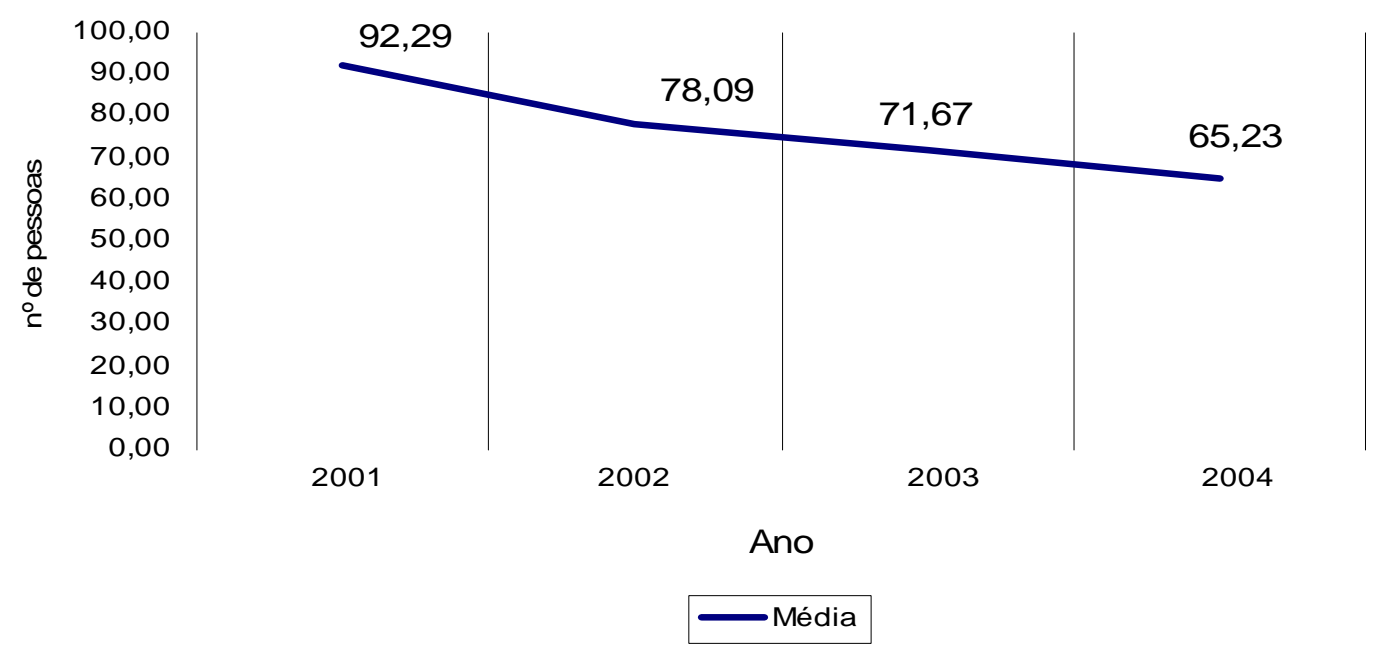

Fonte: Prefeitura de Araraquara 
Os valores dos gráficos 2 e 3 demonstram, mais uma vez, a queda da participação nas reuniões do OP. A partir deles podemos supor que a supressão de etapas antes estabelecidas, como as reuniões explicativas e a Plenária Regional II, contribuíram para essa diminuição.

Os dados da tabela 4 ajudam a fundamentar essa hipótese.

Comparação 2001 - 2004 - Dados detalhados

TABELA 4 - Participação total por etapa de reuniões

\begin{tabular}{lcccc}
\hline & $\mathbf{2 0 0 1}$ & $\mathbf{2 0 0 2}$ & $\mathbf{2 0 0 3}$ & $\mathbf{2 0 0 4}$ \\
\hline Plenárias explicativa & 1196 & Suprimida & Suprimida & Suprimida \\
Plenárias Regional I & 1773 & 690 & 713 & Suprimida \\
Plenárias Sub-regionais & 943 & 1045 & 1229 & 940 \\
Plenárias Regional II & 518 & 1279 & 813 & 1033 \\
Plenárias Temáticas & inexistente & 578 & 542 & 452 \\
Seminário de Prestação de Contas & inexistente & inexistente & inexistente & 137 \\
\hline
\end{tabular}


Gráfico 4 - Participação OP 2001/04 (somente as reuniões realizadas nos bairros)

Participação OP 2001-04 por região

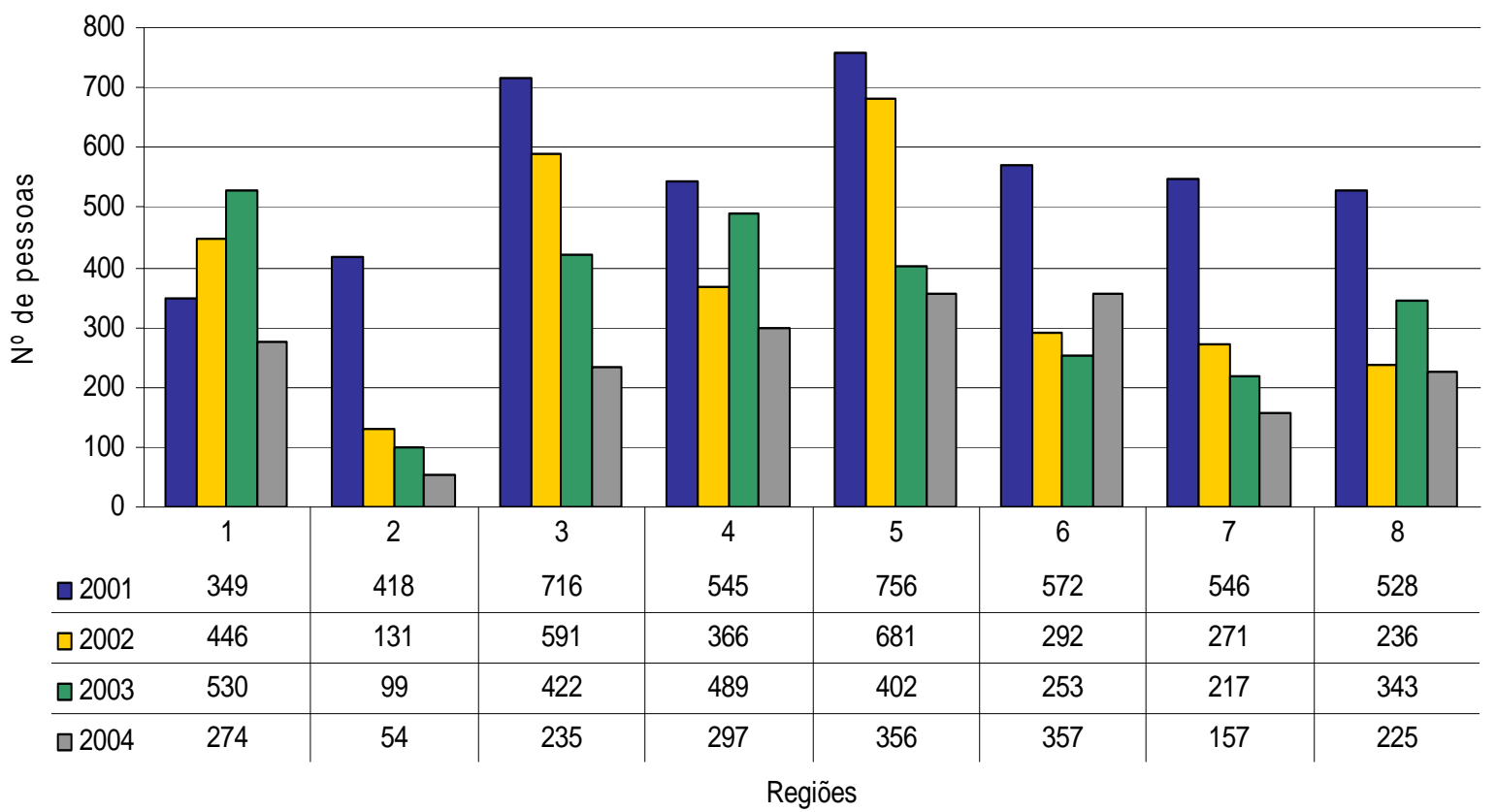

Fonte: Prefeitura de Araraquara

Os dados apresentados no gráfico 4 indicam a participação nas Plenárias realizadas nos bairro, sem contabilizar as Plenárias Temáticas, do Orçamento Participativo deste primeiro mandato da Administração do Partido dos Trabalhadores e indica a flutuação da participação nessas reuniões. 


\section{PERFIL DOS PARTICIPANTES DO ORÇAMENTO PARTICIPATIVO:}

$2001-2004$

Em todas as reuniões do OP, os participantes são cadastrados por um representante da CPP. O participante, ao ser cadastrado, responde de forma espontânea às perguntas do cadastro (cor/raça, escolaridade, data de nascimento, se tem eficiência ou não, etc.). $\mathrm{O}$ número total de participantes cadastrados pela Equipe da Prefeitura Municipal foi de 6133, que coletaram as informações dos maiores de 16 anos (nascidos entre 1901 e 1988). Destacam-se algumas observações sobre o processo de cadastramento realizado nas plenárias do OP:

- O cadastro do OP foi reformulado em 2002, tendo sido incluído alguns itens novos (sexo, escolaridade e cor/raça) e, como os cadastros anteriores não foram atualizados, estes itens são referentes ao OP dos anos 2002, 2003 e 2004.

- Os vários cadastros foram preenchidos de forma incompleta, razão pela qual os números apresentados nos gráficos 5,6,7,8 e 9 são inferiores aos números de pessoas cadastradas.

\section{Gráfico 5 - Participantes por sexo}

Participantes no OP por sexo

\begin{tabular}{l|l} 
Homens: & 2754 \\
\hline Mulheres: & 3255
\end{tabular}

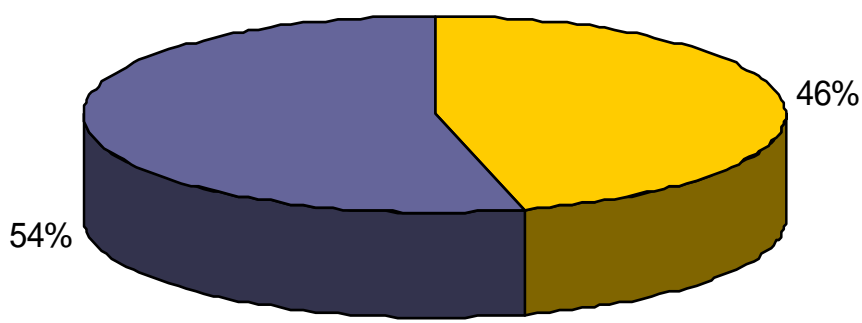

$\square$ Masculino $\square$ Feminino

Fonte: Prefeitura de Araraquara 
Com base nos dados apresentados no gráfico 5 pode-se afirmar que as mulheres na cidade de Araraquara estão se mobilizando mais que os homens para a participação nas reuniões do OP.

\section{Gráfico 6 - Participantes por raça/cor}

\begin{tabular}{l|c} 
Raça/Cor & Total \\
\hline Branco & $\mathbf{1 5 4 7}$ \\
\hline Negro & $\mathbf{6 6 3}$ \\
\hline Mestiço & $\mathbf{3 1 1}$ \\
\hline Oriental & $\mathbf{2 1}$ \\
\hline Indígena & $\mathbf{4}$
\end{tabular}

Participação no OP por Etnia

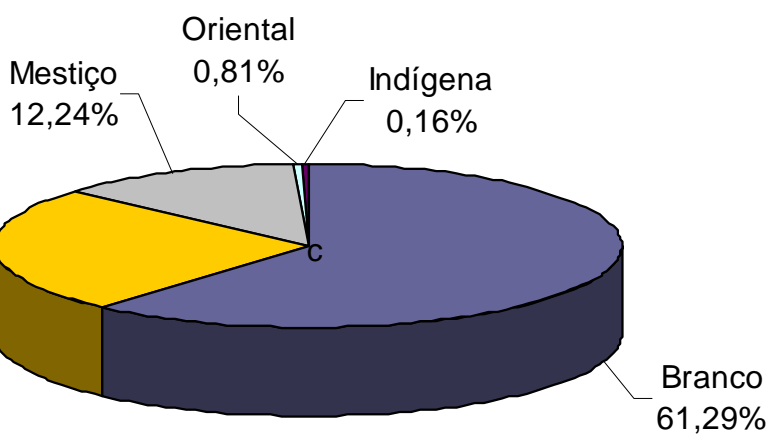

Fonte: Prefeitura de Araraquara

Os resultados apresentados no gráfico 6 mostram que a raça branca apareceu mais, porém sendo significativa a participação dos negros.

\section{Gráfico 7 - Participantes por Faixa Etária}

\begin{tabular}{l|c}
\multicolumn{1}{c|}{ Faixa Etária } & $\begin{array}{c}\mathrm{N}^{\mathrm{o}} \text { de } \\
\text { Participantes }\end{array}$ \\
\hline De 16 a 24 anos & $\mathbf{1 8 0 4}$ \\
\hline De 25 a 64 anos & 3633 \\
\hline $\begin{array}{l}\text { A partir de } 65 \\
\text { anos }\end{array}$ & 449
\end{tabular}

Participantes do OP por Faixa Etária

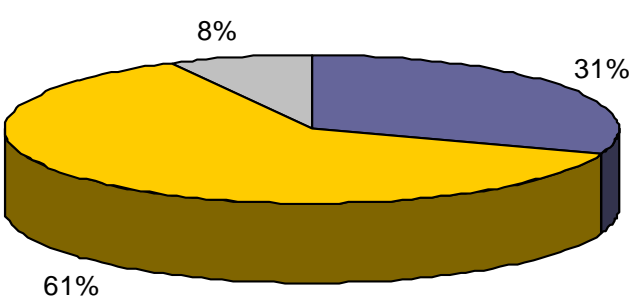

$\square$ De 16 a 24 anos $\square$ De 25 a 64 anos $\square$ A partir de 65 anos

Fonte: Prefeitura de Araraquara

No gráfico 7 é mostrado, como esperado, que o número de adultos na faixa etária de 25 a 64 anos, é a mais numerosa, No entanto merece destaque a significativa participação dos jovens na faixa etária de 16 a 24 anos, correspondendo a 30\% da 
participação e a expressiva participação de idosos, que apesar de representarem menos de $10 \%$ do total, do ponto de vista numérico, 429, são bastante significativos.

\section{Gráfico 8 - Participantes do OP por Escolaridade}

\begin{tabular}{|c|c|}
\hline Escolaridade & Total \\
\hline Analfabeto & 32 \\
\hline Alfabetizado & 9 \\
\hline De $1^{a}$ a $4^{a}$ & 686 \\
\hline $\operatorname{De} 5^{a}$ a $8^{a}$ & 1291 \\
\hline Ensino Médio & 844 \\
\hline $\begin{array}{l}\text { Ensino } \\
\text { Superior }\end{array}$ & 372 \\
\hline Pós-graduação & 2 \\
\hline
\end{tabular}

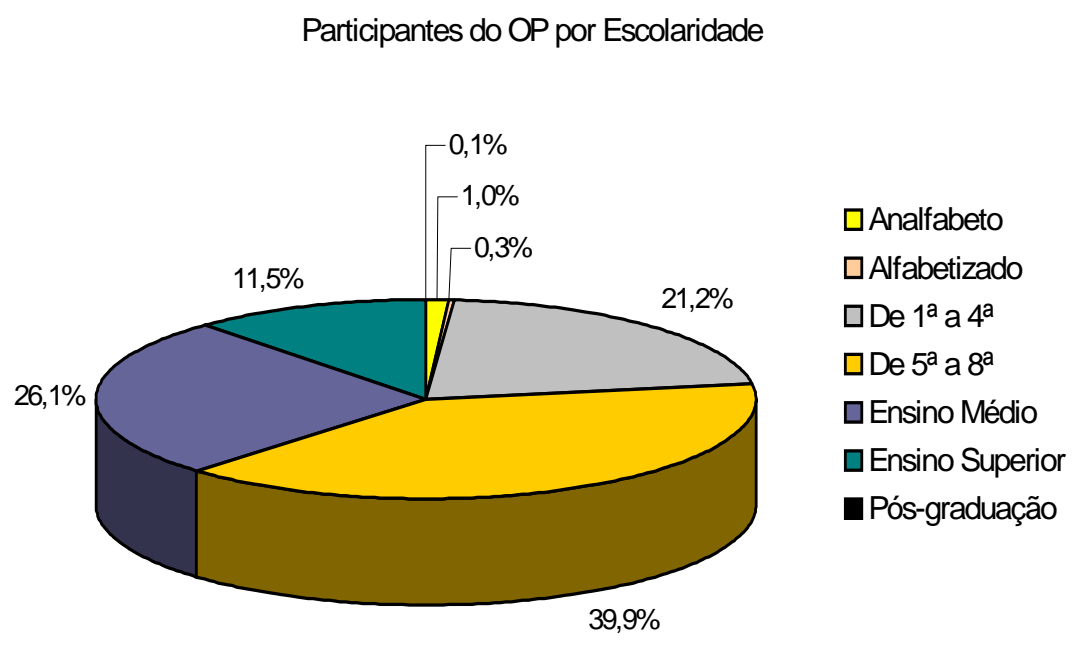

Fonte: Prefeitura de Araraquara

Gráfico 9 - Variação de Escolaridade

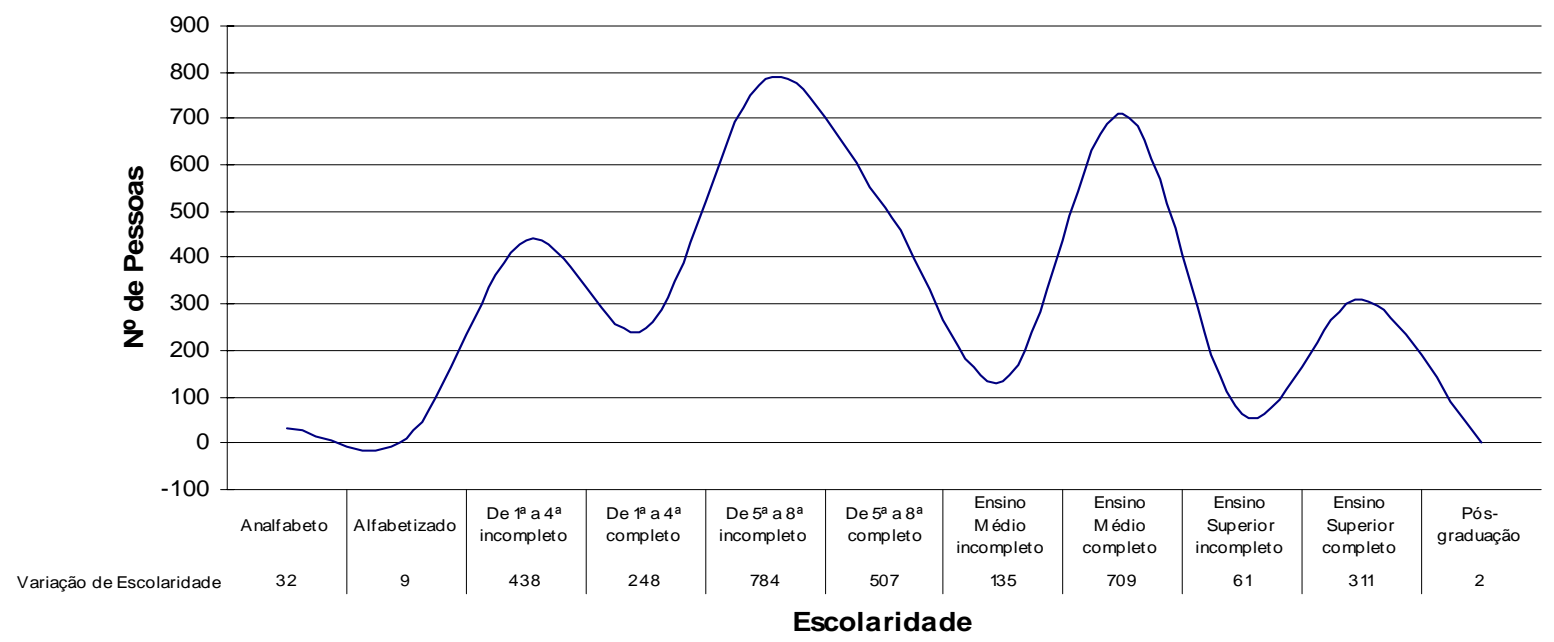

Fonte: Prefeitura de Araraquara 
Os resultados vistos no gráfico 8 surpreendem pela apresentação de mais de $60 \%$ dos participantes apresentarem escolaridade fundamental, sendo a maioria deles, $40 \%$, de Quinta e Sexta Séries e 21\% de Primeira a Quarta Séries. No entanto, é incomum a constatação de 32 analfabetos e 9 somente escolarizados, características incomuns nas pesquisas realizadas em outros municípios. Merece destaque, também, a constatação de que cerca de $1 / 4$ dos participantes possuem Ensino Médio e pouco mais de 10\% o Ensino Superior.

\section{A IMPORTÂNCIA DOS DELEGADOS NO PROCESSO DO OP}

A eleição dos Delegados ocorre na proporção de 10 para 1 . A cada 10 pessoas de um bairro presentes na reunião, esse bairro terá direito a 1 Delegado. Caso um bairro não atinja o número estipulado, fica garantido 1 representante para viabilizar o processo do OP.

Os Delegados têm a função de divulgar as informações sobre o funcionamento do OP, de organizarem os moradores para participarem das reuniões e, principalmente, os mobilizarem para a votação da prioridade do bairro ou sub-região. Para isso eles contam com as informações da Prefeitura Municipal e folhetos informativos.

Além da mobilização e organização da população para participarem das reuniões os delegados também têm como atribuição fiscalizar a elaboração e a execução do plano de investimento e compor comissões que deverão acompanhar as votações da peça orçamentária na Câmara Municipal, o processo de licitação e da execução das obras.

Existem espaços de encontro e de debate para os delegados que são os Fóruns Municipais e os Fóruns Regionais de Delegados. Esses fóruns têm como objetivo a articulação dos Delegados para discutir as prioridades levantadas nas reuniões, conhecendo um a prioridade do outro, para também despertar a solidariedade e verificar o que é realmente necessário para ser executado. Para ajudar nesse processo de discussão das prioridades é feita a Caravana da Cidadania.

A Caravana da Cidadania é um momento dos Delegados visitarem a região e verificarem in locu os temas levantados nas reuniões das sub regiões. Essa visita tem como objetivo estabelecer o relacionamento entre os delegados de uma região e principalmente favorecer o conhecimento da realidade do "vizinho". Ela propicia ao delegado conhecer a sua região e as necessidades emergenciais a serem resolvidas, subsidiando assim a análise 
de cada prioridade levantada e despertando o sentido de solidariedade social. É importante ressaltar que esse procedimento é utilizado em diversas experiências de Orçamento Participativo.

Tabela 5 - Perfil dos Delegados do Orçamento Participativo 2001 A 2004

\begin{tabular}{clc}
\hline & Categoria & Número de Participantes \\
\hline \multirow{2}{*}{ Sexo } & Feminino & 277 \\
& Masculino & 392 \\
& Total & 669 \\
\hline
\end{tabular}

\begin{tabular}{|c|c|c|c|c|}
\hline \multirow{5}{*}{ Faixa Etária } & De 16 a 24 anos & \multicolumn{3}{|c|}{38} \\
\hline & De 25 a 64 anos & \multicolumn{3}{|c|}{380} \\
\hline & A partir de 65 anos & \multicolumn{3}{|c|}{28} \\
\hline & Não preencheu & \multicolumn{3}{|c|}{223} \\
\hline & Total & \multicolumn{3}{|c|}{669} \\
\hline & Brancos & \multicolumn{3}{|c|}{158} \\
\hline & Negros & \multicolumn{3}{|c|}{83} \\
\hline Cor/Raça & Mestiços & \multicolumn{3}{|c|}{31} \\
\hline & Orientais & \multicolumn{3}{|c|}{2} \\
\hline & Indígenas & \multicolumn{3}{|c|}{1} \\
\hline & Não preencheu & \multicolumn{3}{|c|}{394} \\
\hline & Total & \multicolumn{3}{|c|}{669} \\
\hline \multirow{12}{*}{ Escolaridade } & & & & Total \\
\hline & De $1^{\mathrm{a}}$ a $4^{\mathrm{a}}$ incompleto & 23 & \multirow{2}{*}{\multicolumn{2}{|c|}{42}} \\
\hline & De $1^{\mathrm{a}}$ a $4^{\mathrm{a}}$ completo & 19 & & \\
\hline & De $5^{\mathrm{a}}$ a $8^{\mathrm{a}}$ incompleto & 66 & \multirow{2}{*}{\multicolumn{2}{|c|}{119}} \\
\hline & De $5^{\mathrm{a}}$ a $8^{\mathrm{a}}$ completo & 53 & & \\
\hline & Ensino Médio incompleto & 9 & \multirow{2}{*}{\multicolumn{2}{|c|}{102}} \\
\hline & Ensino Médio completo & 93 & & \\
\hline & Ensino Superior incompleto & 3 & \multirow{2}{*}{\multicolumn{2}{|c|}{51}} \\
\hline & Ensino Superior completo & 48 & & \\
\hline & Pós-graduação & 0 & & - \\
\hline & Não preencheu & 355 & & - \\
\hline & Total & 669 & & \\
\hline
\end{tabular}


Analisando a tabela 5 pode-se constatar, apesar do número significativo de não preenchimentos, a não ser com relação ao sexo, que na cidade de Araraquara a participação popular, na modalidade Delegados, ficou centrada na figura masculina, de idade adulta e de cor branca. A variação no item escolaridade, apesar de contar com cerca de $50 \%$ das informações, predomina os de escolaridade fundamental e médio.

\section{CONSELHO DO ORÇAMENTO PARTICIPATIVO E SUAS COMPETÊNCIAS}

O Conselho do Orçamento Participativo (COP) é formado por dois Conselheiros titulares e dois suplentes de cada uma das 8 regiões do OP e das 6 Plenárias Temáticas. Eles são eleitos entre os Delegados que foram eleitos no início do processo.

O Conselho do Orçamento Participativo de Araraquara é deliberativo. Deste Conselho fazem parte os Conselheiros eleitos nas Plenárias do OP, a equipe da Coordenadoria de Participação Popular e os técnicos da prefeitura. A função da CPP é organizar as reuniões e sua pauta. A Equipe Técnica da Prefeitura deverá ajudar os conselheiros, subsidiando-os com informações para que possam elaborar o plano de investimento. Para que isso aconteça, os secretários participam das reuniões do COP e são sabatinados, pelos conselheiros, sobre as questões técnicas para que a prioridade votada, nas Plenárias, possa ser realizada. Somente os Conselheiros representantes eleitos pela população, podem votar nas reuniões sobre as decisões do conselho. A Equipe da Prefeitura tem direito à argumentação no que diz respeito à viabilização do projeto a ser votado.

Os Conselheiros só deliberam sobre a parcela de investimento do orçamento anual. No que se refere ao custeio e à receita, só tomam conhecimento no momento em que a secretaria de finanças apresenta os dados. Durante a elaboração do Plano de Investimento, os Conselheiros analisam o impacto financeiro que a obra de um aparelho público pode dar no orçamento do município.

Para auxiliar na elaboração do Plano de Investimento e também na distribuição de recursos é realizada a Caravana da Cidade, na qual os Conselheiros percorrem as ruas 
analisando as prioridades de cada região e temática. Essa caravana auxilia na decisão dos conselheiros que passam a conhecer a Cidade como um todo, ampliando sua visão de bairro. Essa visita desperta também a solidariedade dos conselheiros em relação às regiões da cidade com desenvolvimento mais precário e com maior necessidade de recursos financeiros.

Durante o processo de elaboração do Plano de Investimentos, os conselheiros se reúnem todas as semanas nos meses de agosto e setembro, concluindo essa etapa com o ato de entrega do Orçamento Municipal à Câmara de Vereadores. Após essa entrega, os conselheiros passam a se reunir uma vez por mês, sendo que nos meses de outubro e novembro participam de um curso de formação junto com os delegados do OP. Esse curso uma carga-horária de 20 horas e é realizado uma vez por semana no período noturno.

O curso tem como objetivos:

\begin{abstract}
Aprimorar a formação das lideranças da sociedade civil que atuam nos diversos canais e espaços de participação popular e cidadã, construídos pela administração municipal e pelos movimentos sociais.

Desenvolver uma melhor compreensão das características do nosso município, da nossa história e das perspectivas para o nosso desenvolvimento.

Desenvolver uma compreensão crítica sobre o poder global e local. Qualificar os participantes dos espaços de participação popular, para que possam agir como agentes autônomos e multiplicadores de conhecimento nas suas esferas de atuação.

Debater a gestão democrática em Araraquara e os instrumentos necessários para o seu aprofundamento e ampliação.

(Prefeitura Municipal de Araraquara, 2003).
\end{abstract}

São desenvolvidos temas que abrangem a história da cidade, as questões de cidadania e direitos, o funcionamento administrativo como o processo licitatório e orçamentário, bem como outras questões de ordem jurídicas e de direitos dos cidadãos.

$\mathrm{Na}$ análise, verifica-se a necessidade dos elaboradores do curso de apresentarem os Projetos Municipais nas áreas de saúde, assistência social e educação, não se limitando apenas às questões de funcionamento, mas também de informação do que está sendo realizado na cidade.

O que se pode observar é que esses cursos são ministrados, no que diz respeito aos temas administrativos, por gestores municipais, o que impede a imparcialidade diante das informações a serem transmitidas. Há também uma preocupação com a formação geral 
desses Conselheiros e Delegados do OP, no que diz respeito aos temas sobre cultura e discriminação, os quais foram realizados por professores da Universidade Estadual localizada na cidade.

Os itens e subitens propostos para a formação dos Conselheiros pela Prefeitura Municipal de Araraquara no ano de 2003 foram:

\section{A cidade, seus atores e conflitos.}

- Nosso papel como indivíduos/cidadãos.

- Os direitos individuais, sociais e coletivos.

- Os cidadãos e o coletivo.

- A Comunidade e nossa co-responsabilidade.

- Poder local: características e funcionamento.

- Desafios atuais de Araraquara e o seu lugar no processo global.

- A importância histórica do Município de Araraquara

- Da concepção tradicional de cidade à construção de uma Araraquara cidadã e solidária.

\section{As políticas sociais no município de Araraquara}

- As políticas sociais e o combate à exclusão no Município de Araraquara.

- A comunidade e nossa co-responsabilidade.

- papel da educação na construção da cidadania participativa. Escola ciclada, escola do campo e conselhos de escola.

- A construção do Sistema Público de Saúde no município de Araraquara.

\section{A estrutura do estado}

- Noções gerais sobre o Estado e suas esferas de poder e competências. 
- O Executivo, o Legislativo e o Judiciário.

- O papel do setor público (importante abordarmos a Administração direta, indireta, autarquias, fundações, empresas públicas, sociedades de economia mista).

- Relação do Estado com o terceiro setor.

- Relação entre o público e o privado (regimes jurídicos diferentes).

- Justiça Tributária e política fiscal

- Estrutura tributária da cidade - IPTU, ISS, Taxas etc.

- Função social da propriedade.

- A importância da reforma tributária.

\section{Lei de Responsabilidade Fiscal}

\section{Orçamento Público e a legislação}

- Orçamento público - Lei de Diretrizes Orçamentárias, Plano Plurianual e Lei Orçamentária Anual.

- Verbas vinculadas.

- Procedimentos administrativos - Lei de Licitações - Lei n. 8.666/93.

\section{Desenvolvimento Urbano: Planejando a cidade}

- Planejamento e desenvolvimento da cidade.

- Plano Diretor. A importância da participação da sociedade na sua elaboração.

- Desenvolvimento integrado e sustentado.

- Política habitacional no município.

- A importância da preservação ambiental para o desenvolvimento sustentável.

\section{Participação Popular na definição de políticas públicas}

- Gestão democrática. 
- Canais de participação popular.

- Controle social.

- Co-gestão.

- O papel do cidadão neste processo.

\section{Poder Público e o combate à discriminação}

- Mulheres, negros e portadores de deficiência.

\section{Cultura e Ideologia}

Pode-se afirmar que os temas escolhidos são pertinentes e mostram a importância dada ao desenvolvimento dos cidadãos, tanto com a preocupação em conhecerem o seu passado e entenderem as relações atuais entre eles e suas relações com o poder público, quanto em passar informações de como esse sujeito pode agir e participar na sociedade.

O desenvolvimento da capacidade crítica do cidadão é de fundamental importância para o exercício da cidadania e a formação de atores sociais, protagonistas da história. Diante disso, pode-se fazer referência a Pont que discute a importância da aprendizagem cidadã que o processo do OP oferece aos seus participantes.

No momento em que se chama a população para discutir, em assembléias, para onde vai o dinheiro público, de maneira organizada, sabendo quanto será a receita, quanto será a despesa, quanto vai para cada Secretaria, quais são os principais tributos, o que vem de cada tributo, quanto se gasta com a manutenção, com o custeio, quanto é que vai para a folha de pagamento, o que é possível investir, - essa socialização de informações contribui para tecer novas relações na sociedade. A disputa da renda da cidade passa a ser um material politizador, conscientizador. (Pont, 2000, p. 80).

$\mathrm{O}$ OP se mostra um impulsionador de agentes sociais, pois possibilita a organização, o diálogo e a mobilização dos moradores de uma região em torno do que é comum, discutindo e debatendo o que será melhor para essa comunidade. Isso possibilita conhecer o funcionamento da cidade e despertar os cidadãos no compromisso com o bem-estar dela. A cidade se torna o espaço de aprendizagem, de relacionamentos e de solidariedade. O OP abre espaço para o surgimento de novas lideranças e desperta para a necessidade do controle social e a co-gestão, fazendo com que as pessoas se interessem 
pelo que é publico e possam participar com maior interferência nos outros espaços de participação existentes no município.

Para exemplificar a questão da aproximação das pessoas aos mecanismos de controle social, bem como a sua interligação, apresentamos uma enquête feita pela equipe da Coordenadoria de Participação Popular. Esses dados foram coletados no ano de 2004 e demonstra o perfil da participação da população que esteve presente no processo do OP daquele ano no que diz respeito ao envolvimento em outras formas de participação e de organização popular.

\section{ESPAÇOS DE PARTICIPAÇÃO - 2004}

Nas reuniões do OP de 2004, foi acrescentado à Ficha de Inscrição um Questionário sobre a participação do cidadão em outros espaços de participação popular que não fossem as reuniões do OP, com o objetivo de potencializar a divulgação do Orçamento Participativo por meio dos próprios participantes das reuniões do OP.

Fonte de dados: Cadastros realizados nas reuniões do OP

Período: Reuniões realizadas em 2004

Critério para seleção: Participantes com mais de 16 anos $^{7}$ (Nascidos entre 1901 e 1988)

\section{Observações:}

1 - Foi considerada somente uma participação de cada participante, desconsiderando o cidadão que participou mais de uma vez durante o ano.

2 - O critério para a tabulação do participante é a região onde reside e não em qual reunião participou.

\footnotetext{
${ }^{7} 16$ anos é a idade mínima para que o participante possa votar em uma reunião do OP.
} 


\section{Questionário acrescentado:}

Participa?

( ) Conselho de Escola

( ) Sindicatos

( ) Grupos de Ginástica

( ) Igreja

( ) Ass. De Moradores

( ) Outros

( ) Grupos de $3^{\text {a }}$ Idade

( ) Conselhos Municipais

( ) CGUS

( ) Grupos Culturais

TABELA 6 - Participação em outros espaços além do OP

\begin{tabular}{cccccccccc}
\hline & R1 & R2 & R3 & R4 & R5 & R6 & R7 & R8 & Total \\
\hline $\begin{array}{c}\text { Total de participantes } \\
\text { no OP }\end{array}$ & 262 & 92 & 240 & 342 & 359 & 191 & 245 & 256 & 1987 \\
$\begin{array}{c}\text { Não participam } \\
\text { Participam }\end{array}$ & 179 & 41 & 155 & 204 & 234 & 118 & 78 & 192 & 1201 \\
Participam (\%) & 83 & 51 & 85 & 138 & 125 & 73 & 167 & 64 & 786 \\
& 31,7 & 55,4 & 35,4 & 40,4 & 34,8 & 38,2 & 68,2 & 25,0 & 39,6 \\
\hline
\end{tabular}

Fonte: Prefeitura de Araraquara

Gráfico 10 - Total de participantes que participam em outros espaços em 2004

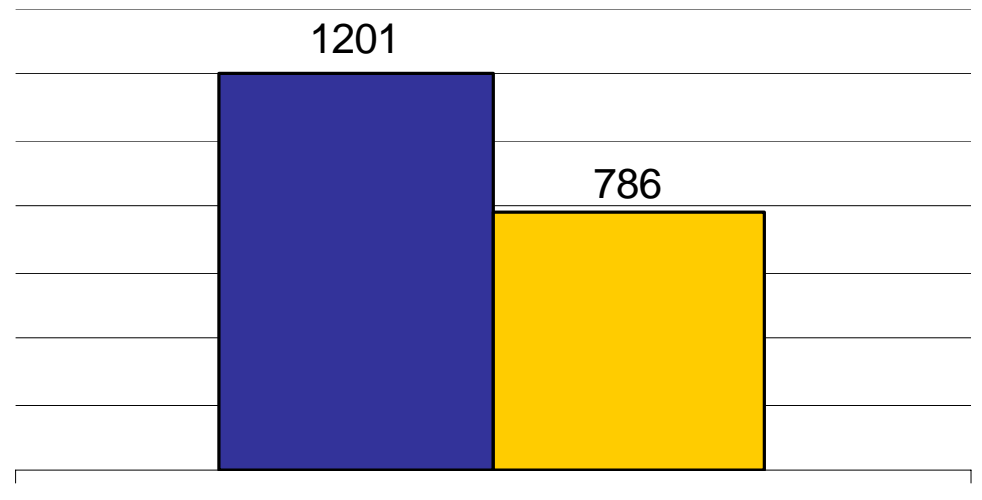

Participantes do OP

๑ Não participam $\square$ Participam de outros espaços

Fonte: Prefeitura de Araraquara 
Os dados da tabela 6 e do gráfico 10 mostram um número significativo de pessoas que participavam em outros espaços, no ano de 2004. Verifica-se também uma grande quantidade de pessoas que estão limitadas a participação no OP (1201 pessoas).

A tabela 6 mostra um percentual considerável. Cerca de 3/5 do total de participantes não exercem outra atividade em outros espaços de participação, fora o OP. Constata-se também que na Região de número 7 é a única cuja tendência de participação é inversa, ou seja, para cerca de 1/3 que não tem outra participação além do OP, 2/3 delas responderam que participam de outros espaços. Uma das hipóteses que pode ser levantada para essa inversão de tendência é o fato da Região 7 aglutinar um número de pessoas mais idosas com uma participação significativa em Igrejas, situação essa atípica para o restante da cidade.

TABELA 7 - Espaços de participação

\begin{tabular}{lcccccccccc}
\hline & R1 & R2 & R3 & R4 & R5 & R6 & R7 & R8 & Total $\begin{array}{c}\text { Total em } \\
\text { \% }\end{array}$ \\
\hline Igreja & 39 & 10 & 29 & 39 & 35 & 43 & 58 & 6 & 259 & $33,0 \%$ \\
Conselho de Escola & 14 & 6 & 13 & 20 & 35 & 15 & 20 & 13 & 136 & $17,3 \%$ \\
Conselho Gestor de Saúde & 3 & 3 & 4 & 20 & 9 & 3 & 13 & 21 & 76 & $9,7 \%$ \\
Grupos de 3 ${ }^{\mathbf{a}}$ Idade & 3 & 5 & 2 & 6 & 17 & 1 & 23 & 3 & 60 & $7,6 \%$ \\
Asso. De Moradores & 5 & 2 & 10 & 6 & 5 & 3 & 4 & 9 & 44 & $5,6 \%$ \\
Grupos de Ginástica & 2 & 4 & 3 & 8 & 3 & 0 & 22 & 0 & 42 & $5,3 \%$ \\
Grupos Culturais & 2 & 7 & 3 & 4 & 6 & 3 & 6 & 0 & 31 & $3,9 \%$ \\
Conselhos Municipais & 2 & 3 & 4 & 3 & 3 & 0 & 5 & 3 & 23 & $2,9 \%$ \\
Sindicato & 2 & 1 & 4 & 2 & 0 & 0 & 3 & 3 & 15 & $1,9 \%$ \\
Outros & 11 & 10 & 13 & 30 & 12 & 5 & 13 & 6 & 100 & $12,7 \%$ \\
\hline
\end{tabular}


Gráfico 11 - № de participantes por espaços

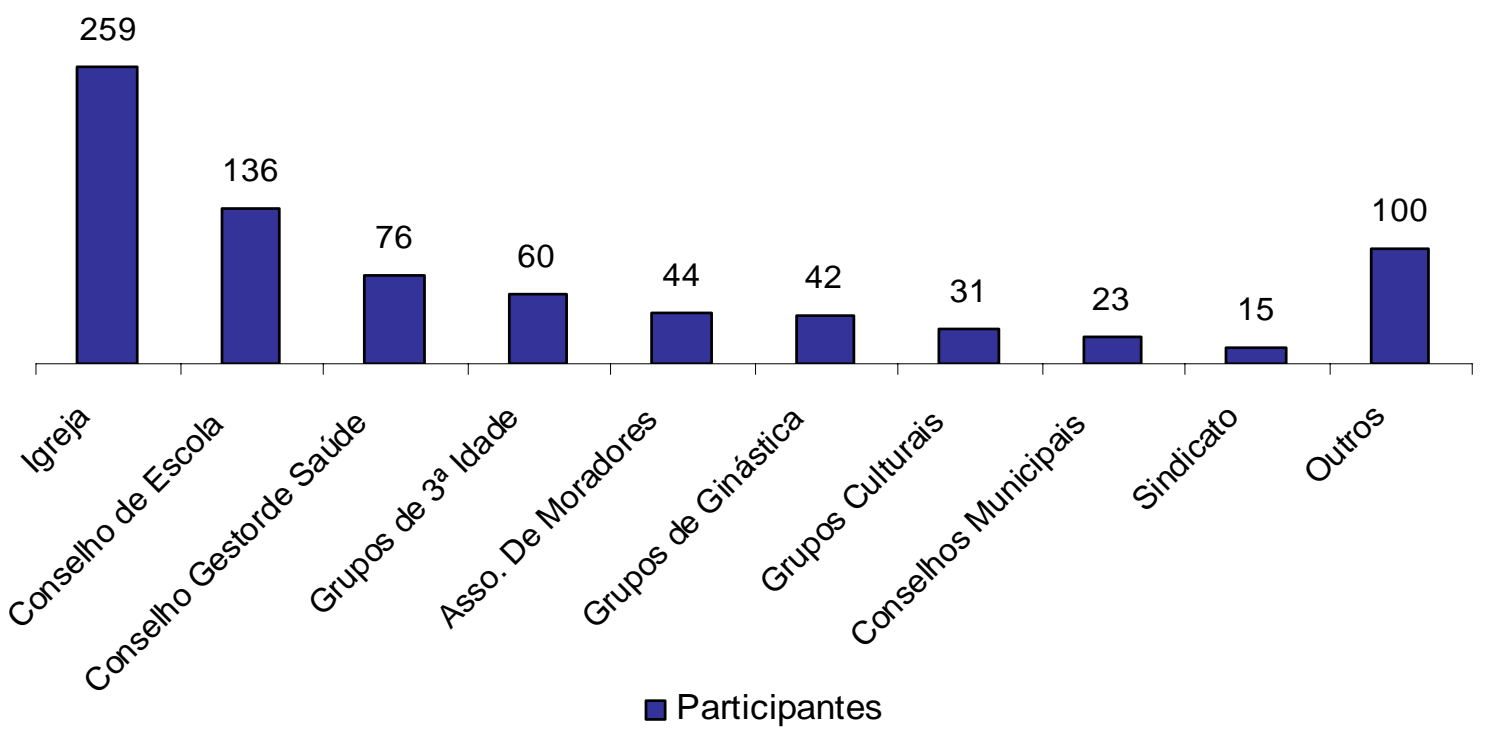

Os valores vistos na tabela 7 evidenciam, de maneira mais específica, os espaços de participação, onde pode ser verificado que, de forma significativa, a participação em Igrejas e no Conselho de Escola, representa 50\% do total de participação e a participação em Conselhos Gestores de Saúde, Grupos de Terceira Idade e Grupos de Ginástica representam outros 28\%, sendo a mais baixa participação, dentre todas elas, é a participação em sindicatos, representando menos de $2 \%$ do total. A tabela confirma, o já mencionado, que a Região 7 apresenta a maior participação tanto nas Igrejas, quanto em Grupos de Terceira Idade e grupos de Ginásticas.

TABELA 8 - Participação em mais de um espaço

\begin{tabular}{lccccccccc}
\hline & R1 & R2 & R3 & R4 & R5 & R6 & R7 & R8 & Total \\
\hline 1 Espaço & 71 & 43 & 68 & 119 & 108 & 68 & 138 & 57 & 672 \\
2 Espaços & 8 & 5 & 14 & 11 & 11 & 5 & 16 & 6 & 76 \\
3 Espaços & 2 & 2 & 1 & 7 & 4 & 0 & 10 & 1 & 27 \\
4 Espaços & 2 & 1 & 1 & 1 & 2 & 0 & 2 & 0 & 9 \\
5 Espaços & 0 & 0 & 0 & 0 & 0 & 0 & 1 & 0 & 1 \\
6 Espaços & 0 & 0 & 1 & 0 & 0 & 0 & 0 & 0 & 1 \\
\hline
\end{tabular}

Os dados da tabela 8 mostram que há pessoas que se mobilizam ocupando pelo menos um espaço de participação, pois do total que responderam a maioria participa em 
outro espaço além do OP. As três regiões que destacam majoritariamente são as regiões 4, 5, e 7, não havendo, nesse caso, uma explicação especial que justifique essa preponderância, o que podemos encaminhar para próximos estudos.

Apesar de não poder medir a intensidade da participação, constata-se que o perfil dos participantes do OP em Araraquara identifica pessoas com interesse em não só atuar em um único espaço de participação. 


\section{CAPÍTULO 4 \\ O QUE AS ENTREVISTAS REVELARAM...}

É importante destacar que as Entrevistas se constituíram em instrumento fundamental para a melhor compreensão do processo de participação popular que o Orçamento Participativo tem como pressuposto.

Ainda que o enfoque das entrevistas se concentrasse na história de vida, sob o aspecto da formação e do aprendizado dos participantes, no que diz respeito à educação para a cidadania, via OP e outras experiências vividas - anteriores, paralelas ou concomitantes - (anexo G) elas acabaram por levantar diferentes questões que superaram, em muito, o estabelecido no Roteiro Básico.

Assim, uma das primeiras questões feitas nas entrevistas, dizia respeito às experiências de participação anterior ao ano de 2001, quando iniciou a Administração “Democrática e Popular” (2001-2004), com a eleição do Partido dos Trabalhadores, na Cidade. A análise dos depoimentos nos permitiu traçar um interessante "quadro da situação”, pois, verificou-se que entre os entrevistados, 59\% não tinham nenhuma participação em qualquer tipo de grupo social - para além da família - que 14\%, participavam em Clubes Esportivos, 14\% participavam de alguma Associação de Moradores, 9\% haviam participado de algum tipo de Organização Social em outras Cidades e 4\%, em atividades sindicais.

Em período mais atual, incluído o da Pesquisa (2001/2004), 82\% desses mesmos entrevistados declararam que, além de sua participação no OP, participavam de mais de uma atividade e $18 \%$, apenas, de uma única atividade de participação popular ou associativa. A maioria informou estar envolvida com algum tipo de Conselho de Políticas Públicas locais, seja o Conselho Gestor da Unidade Básica de Saúde, o Conselho de Escola, ou o Conselho dos Usuários do Transporte Coletivo.

Em menor quantidade, aparece a alternativa de participação em Conselhos em nível mais geral da Cidade, ou seja, em Conselhos Municipais. Ficou identificada, em menor número, a participação em Associações de Moradores e quase no mesmo percentual, a participação em Partidos Políticos. Os menos citados, surpreendentemente, foram as participações em entidades religiosas, sindicatos e ONGs.

O que foi pode ser constatado, através dos depoimentos, é que os entrevistados estabelecem uma ligação estreita entre as diversas formas de participação popular, 
reconhecendo, de forma explícita, que o OP é o catalizador delas. Muitos dos entrevistados afirmaram que eles se sentiram motivados a participar de outros movimentos, depois de começarem a participar do OP em Araraquara e que, para eles, o OP atuou como um estimulador para a participação em outros espaços.

Os depoimentos indicam, inclusive, que algumas Associações de Moradores foram criadas a partir da "descoberta” de novas lideranças, que foram surgindo - ou se revelando - com e no processo do OP. Essas pessoas alegaram, também, que perceberam, a partir do $\mathrm{OP}$, a necessidade de se organizarem para terem mais força para reivindicar as melhorias para os bairros.

Alguns chegaram a reconhecer que a relação entre o OP e os Conselhos Setoriais “é uma contribuição de mão dupla para a participação” (entrevistados 4, 5, 7, 9, 13, 17, 19 e 21). Outros (entrevistados 3, 8, 11, 12, 15, 20 e 22), justificaram que alguns dos participantes se interessaram em participar dos Conselhos por terem se envolvido no processo, enquanto outros fizeram o caminho inverso, ou seja, já estavam participando do Conselho e perceberam que o OP era um espaço de participação importante para definição de assuntos referentes a sua área de atuação, isto é, ao Conselho a que ele pertencia.

O que se pode afirmar, pelas entrevistas feitas, complementadas, também, com as observações realizadas nas Plenárias do OP e nas reuniões do Conselho do OP é que há uma constatação e reconhecimento de que se deu, de fato, um desenvolvimento pessoal com vários dos entrevistados. Muitos declararam que houve uma mudança no seu jeito de ser, isto é, perderam a timidez que os impedia de se expressar em público por se acharem sem capacidade para isso. Com a participação sistemática e regular, que o OP cria e estimula, alguns foram perdendo o medo de falar e de expor suas idéias e opiniões, bem como começaram a se interessar mais pelo que acontece na Cidade (“impressões” estas presentes em 16, dos 22 depoimentos).

A abertura de espaços para discussão dos problemas dos bairros, deu a eles, de forma reconhecida, a dimensão de que era possível se reunir, e através desse processo, ajudar as pessoas do bairro e da Cidade, possibilitando uma maior integração social, assim como, a percepção mais consistente de que essas diferentes alternativas de participação podem gerar, nos envolvidos, consciência política e social, em potencial, para contribuir, de forma mais coletiva, com sua cidade e o seu bairro (entrevistados de $n^{\circ}: 2,7,11,14$, $25,17,18,20$ e 22$)$. 
Um outro evento, especialmente destacado pelos entrevistados foi a "Caravana", atividade que é feita pelos conselheiros do OP, através da qual eles visitam as regiões, a fim de melhor decidirem sobre as prioridades dos bairros. Esse processo, confessam os entrevistados, desperta o sentimento de pertencer a uma cidade, pois os Conselheiros começam a conhecer a realidade dos outros moradores e não somente a sua.

Esse momento gera um aprendizado do que deve ser feito pela Cidade e, principalmente, de seus participantes perceberem as necessidades de outros bairros, gerando, assim, um espírito de solidariedade, pois, em alguns casos, eles deixam de reivindicar as suas próprias demandas, em prol de bairros mais carentes.

Aprendi no $\mathrm{OP}$ a não me preocupar só com a gente. Aprendi a ver a necessidade de cada bairro e não ser egoísta e ter interesse próprio. Tem que beneficiar o maior número possível. O OP não é o "eu”, é um todo. (entrevistado 1)

Destacamos um segundo depoimento, em que foi enfatizado o caráter solidário desse processo:

É uma reeducação social. De repente eu aprendi que o bairro que eu moro tem suas necessidades, mas não tão importantes como as necessidades do meu vizinho que está lá do outro lado da cidade. Isso me deu uma visão... me deu a sensação agradável de perceber que eu posso ajudar as pessoas. (entrevistado 2)

Essa questão de conhecer melhor a Cidade em que vivem foi destacada também por aqueles representantes que têm por função mobilizar as pessoas de seu bairro, para participarem das reuniões do OP. Elas destacaram nas entrevistas, que outros moradores, participantes do OP, decidiram participar das reuniões do OP, em seus bairros, enfatizando esse aspecto, como um fator fundamental (entrevistados $n^{\circ} .5,8$, $11,12,18$ e 20$)$.

Depois que eles começam a participar, começam a ver as necessidades de outros bairros. (entrevistado 3)

Com a participação, esses sujeitos se sentem mais fortes para reivindica e dar sugestões para a resolução de conflitos. A partir dessa motivação inicial, começam a se interessar pelos “caminhos” por onde percorre o dinheiro público, o papel real dos impostos e o custo dos serviços públicos e, portanto, onde se deve empregar as verbas vinculadas nas áreas da educação e da saúde. As pessoas se sentem mais esclarecidas sobre a forma como é empregado o dinheiro público. O OP possibilita um conhecimento mais objetivo de como funciona a Administração Pública e a partir disso, as participantes começam se sentir mais responsáveis pela Cidade em que vivem. Começam a perceber que não basta só votar no “Dia das Eleições”, já que no Brasil o processo eleitoral é 
obrigatório, mas que é necessário, também e principalmente, fiscalizar a atuação de quem foi eleito e de participar junto dessa Administração (entrevistados $n^{0}: 1,2,5,8,9,12,14$, 19 e 22) .

“Tomam consciência”, expressão freqüentemente utilizada, do que é a Administração Pública, e de como são gestadas as políticas públicas, e isso passa a se constituir um patrimônio de todos. Ao participar da construção dessas Políticas, de seus projetos e obras, as pessoas começam a se interessar pela sua fiscalização e de tratar com maior respeito esse bem público, pois, agora, conhecem o valor financeiro de cada obra.

Quinze entrevistados afirmaram acreditar que quando a demanda que o bairro fez foi atendida, a comunidade se organiza para cuidar daquilo que conquistou, pois aprendeu a valorizar e a cuidar do patrimônio público.

Pessoalmente, depois que comecei a participar dos conselhos e do OP, a gente passa a perceber de uma maneira diferenciada de quando se é menos ativo. A gente vê com o desejo de melhorar aquilo que serve a comunidade, sempre prestando atenção nos detalhes que precisa de uma melhoria e tende a levar para os espaços públicos as reclamações daquilo que é necessário fazer. (entrevistado 4).

Com essa participação, disseram, o cidadão aprende o funcionamento da máquina pública. Ele começa a ter a dimensão do que é o Município, conhecendo a área urbana e a zona rural. Desperta, então, para a necessidade de se pensar a Cidade que eles querem no futuro e de ter acesso igual aos benefícios e serviços que ela oferece. Sendo assim, esse envolvimento faz com que as pessoas pensem em assuntos relacionados às questões municipais e despertem para a vontade de colaborar.

Antes da participação no OP e no conselho de escola a gente não via nada, não escutada nada do que acontecia na cidade... o dinheiro está indo pra tal lugar..., foi feito isso.... agora está sendo mais divulgado as coisas, os postos de saúde, a escola. O povo está participando mais, tanto na escola, porque hoje tem conselho de tudo praticamente, está sendo válido. (entrevistado 3)

Esse processo, afirmaram oito dos entrevistados (entrevistados de $n^{0} 2,3,8,11,13$, 14, 19 e 20), amplia a visão do que é ser cidadão, pois, participando do OP, as pessoas começam a perceber que Política não é apenas eleitoral. Ela se relaciona com o dia a dia das pessoas e há a necessidade de se fiscalizar o Governo, e é um direito e um dever, expressar suas opiniões.

Você é e se sente mais estimulado em participar de movimentos. No mínimo a gente aprende como funciona a máquina. Agora podemos dizer que somos cidadãos com dignidade e isso estimula cada dia mais a participação. Direito de saber que você é alguém. (entrevistado 2). 
Ficou evidenciado nas entrevistas que a existência de espaços de participação possibilita que os cidadãos se tornem "sujeitos” e não elementos passivos na questão política, e que o OP tem um papel importante, auxiliando a construção, no dia-a-dia, dessa cidadania.

Ele (OP) abre amplamente a possibilidade de participação e discussão e isso tudo vai possibilitando que você encontre seu espaço político, que se encontre como cidadão inserido no contexto social e no funcionamento deste social que envolve a questão político administrativo e deixa de ser alienado e passa a ser um cidadão consciente. (entrevistado 4).

O que ajuda nessa percepção, e foi colocado pelos entrevistados, é a transparência que esse processo propicia. A partir do momento em que se toma conhecimento do funcionamento da Administração Pública as pessoas sentem que têm o direito de falar, elas se apropriam desses espaços e se tornam fiscais das ações que foram determinadas no processo participativo.

Abriu muitos leques. A gente fica por dentro da vida política da cidade. Com certeza foi um grande passo na minha vida. (entrevistado 5).

Verificou-se que, com essa participação popular, houve uma valorização pessoal de seus participantes, uma vez que esse processo estimula o potencial de cada pessoa, e eles se sentem valorizados. Alguns chegaram a afirmar que, pela participação, sentiram que foi despertado, também, seu espírito de liderança e começaram a entender o seu papel como cidadão.

O poder de se sentir visto e ouvido. Modifica a vida da pessoa porque tem consciência e esperança. O que gera a vida é a esperança de mudar ela. Quando se envolve a pessoa critica, observa... (entrevistado 6)

Esse envolvimento com a Cidade, enfatizam os entrevistados, contribui para a socialização de seus moradores, pois faz com que essas pessoas, que antes eram apenas “indivíduos no meio da multidão” (entrevistado 7), se integrem à vida do município, tornando-se cidadãos que participam das decisões que dizem respeito a sua vida naquele momento.

Eu aprendi a gostar da cidade e me sentir parte dela. Sinto-me responsável por cada decisão, que posso fiscalizar, observar. Ter mais conhecimento do que é direito e mais informações de órgãos públicos e, assim, não depender de vereadores que se projetam na miséria, miséria até mesmo intelectual das pessoas. (entrevistado 6). 
Os depoimentos nos permitem afirmar que essas pessoas passaram a entender a cidadania como sendo participação dos cidadãos em busca de seus direitos. A questão dos direitos sociais e a luta por eles, se tornaram argumento forte quando eles expressam suas reflexões sobre cidadania.

Verificamos que essa participação, especialmente no OP, estimula, também, o questionamento do Estado em relação às questões que envolvem a educação, a saúde, a moradia, bem como a defesa dos direitos iguais para todos.

A participação ajuda muito a verificar os seus direitos e faz com que essa pessoa se torne importante dentro da comunidade e da sociedade. Ela sabe que é importante e vai se sentir satisfeito por isso. Ela vai falar e vai ser escutada. (entrevistado 7)

As outras questões que foram levantadas sobre o tema "Cidadania" podem ser resumidas nas seguintes considerações: 1) entende-se por cidadania o acesso igual à cidade, ou seja, a cidade passa a ser de todos; 2) ela faz com que aja integração entre um bairro e outro, juntamente com as Associações de Moradores; 3) ela desperta para o exercício da solidariedade; 4) a pessoa se torna um cidadão participante na comunidade em que vive; 5) começa a existir disponibilidade e organização para melhorar os bairros; 6) a consciência da cidadania estimula a participação política, pois as pessoas passam a ter interesse e querem ter conhecimento sobre o que é feito com o dinheiro público.

O araraquarense está sentindo que participando ele tem voz ativa é importante, porque tem como reivindicar. (entrevistado 8)

Pode-se, portanto afirmar, a partir das entrevistas realizadas, que os espaços abertos pela gestão democrática podem favorecer, de fato, a cidadania ativa, pois essas pessoas começaram a se sentir sujeitos de direitos, descobrindo o valor do espaço público e expressando suas opiniões, a partir da confiança que se estabelece entre os participantes, a partir dessa convivência. Essa participação, declararam eles, faz revitalizar sentimentos como a tolerância, a igualdade, a justiça e a solidariedade, revelações estas que confirmam o que Benevides chamou de "virtude ativa” (1996) e estas, por sua vez, possibilitam o aprendizado para a tomada de decisões em relação às prioridades sociais.

Nesse mesmo sentido, Konder (2003) destaca que essa solidariedade, característica da aprendizagem nesse processo, está associada “à idéia de responsabilidade de todos pela carência ou necessidade de qualquer indivíduo ou grupo social.” (p.64). Analisado dessa forma, poderíamos afirmar que esse sentimento de solidariedade, que é valorizado, passa a 
ser entendido como a realização dos direitos sociais, visando a que todos possam ter condições dignas de vida e acesso igual à Cidade.

Não foi, também, sem uma certa surpresa que constatamos que alguns dos entrevistados fizeram referência ao Prof. Paulo Freire, para fundamentar sua opiniões, em especial, o destaque que o prof. Paulo Freire dá, em relação à prática educativa que se estabelece num processo permanente na vida das Cidades, por intermédio das diferentes atividades e seus contextos, ao considerá-los educativos entre si. Nesse sentido, a participação se torna um ato de decisão, no qual o sujeito aprende por meio de sua atuação nessa tomada de decisão (Freire, 2003).

Foram recorrentes, também, os depoimentos sobre uma mudança de mentalidade, na qual o sujeito começa a perceber o mundo que está em sua volta, que um número significativo deles mencionou (entrevistados $\mathrm{n}^{\circ}$ 2, 3, 7, 9 11, 12, 15, 16, 18, 19 e 22). Como conseqüência desse processo formador, disseram nove dos entrevistados, ele passa a assumir na sua vida, um papel de cidadão ativo, que participa da vida da escola de seu bairro, de Posto de Saúde e da decisão de gerir os recursos de sua cidade, conhecendo-a melhor e sentindo-se responsável por ela. Esse processo, argumentaram os entrevistados mais "entusiasmados”, forma lideranças que passam a ter mais acesso à informação, melhoram a sua vida pessoal, pois possibilita uma auto-estima que o seus cotidianos não lhes possibilitava, e, em especial, o sentimento de pertença a um lugar, uma comunidade, uma Cidade (entrevistados $n^{0}: 1,5,6,9,13,14,27,20$ e 22).

Em função das entrevistas realizadas, enfatizando, sobretudo as formas de participação da população em mecanismos de Gestão Democrática, tendo como referencial o Orçamento Participativo, pode-se afirmar, mesmo com as dificuldades e limitações apontadas, que a hipótese inicial desse trabalho, de que o processo de Gestão Democrática colabora com a formação e o aprendizado dos participantes, é confirmada. Esse aprendizado, por sua vez, nos termos dos depoimentos obtidos, não só ajudou esses cidadãos a perceberem a importância da participação em outros mecanismos de definição de Políticas Públicas, acompanhamento ou controle social das mesmas, como por exemplo, os diferentes Conselhos existentes na Cidade, como, muitas vezes geraram a motivação necessária para essa participação em espaços diversificados. 


\section{O PROCESSO EDUCATIVO E A PARTICIPAÇÃO POPULAR: ALGUMAS CONSIDERAÇÕES}

Pelo estudo de campo realizado, tanto através das entrevistas como das observações e acompanhamento ativo das diferentes reuniões do OP, acrescidos dos dados obtidos nos documentos oficiais, e ainda, considerando o referencial teórico utilizado como base para essa Pesquisa, pode-se afirmar que o que foi proposto como hipótese inicial do trabalho, em algum grau, foi confirmado.

O conjunto de informações obtidas nos permitiu constatar que o processo educativo de uma Gestão que se propõe a democratizar os espaços públicos e que valoriza a participação popular auxiliam no processo educativo da população participante. Verificou-se que o OP auxilia na mobilização das pessoas e desperta para práticas participativas, bem como estimula a cidadania ativa favorecendo uma relação entre os diversos espaços de participação existentes.

Constatou-se, também, pelas análises realizadas, que a educação para a cidadania se desenvolve desde o momento inicial da primeira participação do cidadão no processo do OP, que por sua vez, estimula a integração entre esses mecanismos de participação, como os Conselhos, possibilitando oportunidades cada vez mais complexas do exercício da cidadania e, em conseqüência, motivam o desenvolvimento de uma cultura política participativa.

Apesar dos aspectos positivos levantados pela Pesquisa, também é necessário evidenciar que esse processo "ideal” de formação cidadã ainda tem um desenvolvimento limitado, precisando ser assumido pela população como seu direito de cidadão e não, simplesmente, uma concessão especial que esse ou aquele Governo Municipal possibilite.

Assim, destacamos alguns questionamentos observados sobre o processo do OP de Araraquara, que, evidentemente, não anulam a importância do mesmo, mas são indicadores que essa nova “concepção” de gerir a Cidade, ainda precisa sofrer aperfeiçoamentos e, até mesmo, pressão da população, na definição precisa de seus rumos.

Constatou-se, por exemplo, que a participação nas reuniões do OP não ultrapassa os 6,5\% da população do município, ainda que a mesma tenha se demonstrado cada vez mais qualificada, pois as pessoas reconhecem a importância desse espaço democrático de discussão orçamentária e, portanto, as suas intervenções no mesmo, têm um efeito de caráter politizador para os participantes. 
Constatou-se, também, que quem participa, na sua maioria, são os representantes dos grupos sociais mais pobres da Cidade, que reivindicam melhorias pontuais e emergentes para as suas regiões, como pavimentação, unidade de saúde, escolas. O acompanhamento das reuniões, no entanto, permite considerar que já começa a existir uma preocupação com a questão da cultura e com os espaços de convivência de movimentos culturais pelos participantes, que começam a tomar forma e a se organizar.

No que se refere à autonomia, percebe-se que no processo do OP de Araraquara existe, ainda, muita deficiência, pois Delegados e Conselheiros são muito dependentes da CPP. No Regimento Interno é previsto como função dos Delegados, a realização dos Fóruns Regionais, mas esses Fóruns só acontecem com a organização e mobilização da Prefeitura Municipal. Sendo assim, esses Delegados só se reúnem quando a própria Administração Municipal tem alguma questão específica a tratar ou quando os convoca para ajudar na mobilização do bairro.

Da mesma maneira, os Conselheiros não disputam seu espaço de autonomia (que lhes é de direito pelo Regimento Interno do OP), tornando-se dependentes da organização ditada pela Administração Municipal. Apesar de o Conselho ter uma coordenação, quase sempre, é a CPP que marca ou desmarca as reuniões, elabora a pauta e conduz as reuniões. As Comissões que são formadas para o acompanhamento do Orçamento na Câmara, das Licitações e Acompanhamento das Obras também são dependentes da organização da Equipe da Prefeitura Municipal, conforme o observado nas reuniões, em diferentes momentos do processo do OP.

De certa forma, constatou-se o baixo grau de organização popular da população pesquisada, o que indica a existência, ainda, de falhas no processo de formação, relevando-se este fato, em função, principalmente, do pequeno período de tempo de sua implementação. Em conseqüência, os Conselheiros não se sentem totalmente responsáveis pelo processo como um todo, não se mostrando ainda capazes de tomar decisões sem estarem subsidiados - e até mesmo subordinados - aos técnicos da Prefeitura Municipal.

Pode-se perceber, no entanto, que esse mecanismo favorece um cenário para a participação e educação cidadã, sendo, ainda, necessários investimentos constantes e continuidade, o que indica que a mesma precisa se tornar uma Política Pública de Estado e não, simplesmente, uma Política de Governo.

Para que isso se viabilize, no entanto, faz-se necessário uma Reforma do Estado, 
precedida de amplos debates com a população, no que diz respeito à ampliação dos direitos sociais e as possibilidades de controle social participativo, uma vez que qualquer redefinição das relações entre o Estado e a sociedade civil, pressupõe um novo - e sempre difícil- Pacto Social, frente às atuais condições histórias de descenso dos movimentos sociais.

Outra questão que a construção de uma participação popular autônoma envolve, é que a mesma não acontece de forma imediata. A participação efetiva das pessoas é construída com o tempo. Leva tempo. E como já se apontou, e a prática histórica comprova, só se aprende a participar, participando.

Esse processo do OP, no entanto, tem características especiais, pois também educa pelo processo da transparência no trato com o dinheiro público e com os dados técnicos que são disponibilizados, com uma certa freqüência, possibilitando que os cidadãos possam se apropriar dessas informações e ampliarem seus conhecimentos.

Nesse sentido, a própria Gestão Democrática possibilita o desenvolvimento de uma educação para a cidadania, pois possibilita que seus participantes deliberem sobre assuntos referentes ao seu bairro e à sua cidade, estimulando a co-gestão e desenvolvendo um sentimento de responsabilidade, mais coletivo, pelo Município, isto é, pelo que é público.

Essa prática se dá no decorrer do exercício da cidadania ativa, no âmbito da democracia direta que tenha como objetivo formar cidadãos autônomos, que sejam críticos e que exerçam seu direito de falar, opinar e escolher o que é melhor para seu grupo social e para sua Cidade.

As pessoas se identificam com esses mecanismos e sentem necessidade de participar, seja pela elevação da auto-estima, que se fortalece quando as pessoas sentem que são ouvidas e atendidas, seja pelos valores que são despertados durante esse processo, como a solidariedade, a igualdade e a justiça social.

Sendo assim, esse processo educativo se auto-alimenta possibilitando o convívio entre os participantes - antes, pessoas desconhecidas entre si - e incentivando a troca de experiências. O que se espera é que os participantes alcancem uma automonia para se auto-organizarem, mas, conforme apurado nas entrevistas, os participantes ainda consideram ser necessário que os Governos Participativos sejam os facilitadores desse processo e tornem a Cidade, a grande estimuladora da participação.

Um dos recursos que poderia contribuir para isso, como se pode anotar na maioria 
dos depoimentos dos entrevistados e mesmo nas manifestações ao vivo, nas Plenárias, são os cursos de formação, que conforme eles citam, representam investimento que possibilita ao cidadão, o acesso ao conhecimento, à reflexão e à automonia. Não por acaso, o próprio Prefeito Municipal, acreditando também nisso, ministrou - conforme Relatórios consultados - aulas, em vários dos cursos, em especial, discutindo a noção de Estado, e sua relação com a sociedade Civil.

Observou-se, com razoável freqüência, que o OP, para os participantes, motivou que eles se tornassem interlocutores dos Conselhos existentes na Cidade. Essa aproximação e interligação, apostam eles, auxiliam no aprendizado da Cidade, colaborando para o entendimento do que é ser um cidadão que se faz presente, sempre, na sua Cidade.

Como todo processo educacional, constatou-se, o mesmo precisa ser aprimorado e estimulado, pois a participação pode trazer benefícios para o cidadão, mas se o processo não for, realmente, transparente e não traduzir um real espaço de divisão de poder, a participação popular pode se esvaziar e chegar ao seu limite. Nesse sentido, os Conselhos, em Araraquara, precisam investir mais na formação de seus membros, para que os mesmos possam ter uma atuação mais qualificada. Para isso, é preciso capacitar os participantes, sejam eles representantes da população, ou membros do próprio Governo Municipal, uma vez que, há longo tempo, as Administrações Públicas não investem numa formação consistente e atualizada de seus funcionários.

Os temas debatidos nos Conselhos e, também, no OP se referem às prioridades de investimentos na Cidade, sendo esse o primeiro agente mobilizador para a participação e, também, para a integração entre as diversas formas de participação popular. A dificuldade existente entre os participantes, conforme se constatou nos depoimentos, é ultrapassar essa primeira iniciativa, que podemos chamar de "fazer”, isto é, construir algo físico. As intervenções nas questões de Políticas Públicas ainda não os mobilizam, razão pela qual, conforme depoimentos de alguns representantes do Governo Municipal, não se tornaram Pauta constante nas discussões dos Conselhos e do OP. Constatou-se, inclusive, em todo o processo, que muitos que participam, ao conseguirem que sua reivindicação seja atendida, não mais retornam ao processo do $\mathrm{OP}$, ou se desmobilizam para continuar participando dos Conselhos.

Essas observações são importantes para mostrar que o processo de formação é dinâmico e tem que ser aprimorado, permanentemente. Tanto o OP, quanto os 
Conselhos, são mecanismos de participação que vão se transformando, pois é esta plena realização do mesmo, que gera suas novas necessidades. A cultura da participação vai sendo implementada, gradativamente, e vai se sedimentando ao longo da história de cada Cidade, e mesmo de cada processo de participação que se completa.

As questões aqui analisadas, evidentemente, não têm uma solução imediata, elas fazem parte de um processo de construção da cidadania e, portanto, esse estudo não se esgota nesta pesquisa, mas ele pode sugerir caminhos para um aprofundamento desse tema em futuras pesquisas.

Como já se enfatizou, há muito que avançar, mas verificamos que o caminho para uma educação para a cidadania se faz no dia a dia e nos espaços de atuação dos cidadãos. A importância dessa educação que acontece em um sentido amplo, demonstra que a Cidade pode ser educadora e que a multiplicação dos espaços participativos pode se constituir em uma experiência estimulante, onde se eduque e se exercite a prática da cidadania.

Aprender para nós é construir, reconstruir, constatar para mudar, o que não se faz sem abertura ao risco e à aventura do espírito (Paulo Freire, 1996, p.77) 


\section{REFERÊNCIAS BIBLIOGRÁFICAS}

- Indicadores da Cidade de Araraquara. Disponível em:www.araraquara.sp.gov.br. Acesso em: 25/01/2006.

- Projeto Educacional Para a Rede Municipal de Ensino. Disponível em:www.araraquara.sp.gov.br. Acesso em: 25/01/2006.

Projeto Orçamento Participativo de Santo André/SP. Disponível em: www.santoandre.sp.gov.br. Acesso em 19/07/2006.

Projeto Orçamento Participativo de Porto Alegre/RS. Disponível em www.portoalegre.rs.gov.br. Acesso em 14/07/2006.

ARARAQUARA, I CONFERÊNCIA MUNICIPAL DE EDUCAÇÃO, 2001, Araraquara. Conferência Municipal de Educação: Educação para a Cidadania. Mimeografado.

ARROYO, M. Educação e Exclusão da Cidadania; in Buffa, E. Educação e Cidadania, SP: Cortez, 2003.

AVRITZER, L. Modelos de Deliberação Democrática: Uma Análise do Orçamento Participativo no Brasil. In: SANTOS, B. De S. [org.] Democratizar a Democracia: Os Caminhos da Democracia Participativa. Rio de Janeiro: Civilização Brasileira, 2002.

BASTOS, J. B. (org.). Gestão Democrática. RJ: DP\&A: SEPE,1999.

BENEVIDES, M.V. Democracia e Cidadania. In: BOAS, Renata Villas. et al. (org.) Participação Popular nos Governos Locais, São Paulo: Pólis,1994.

. Educar para a Democracia. Revista Lua Nova, SP, CEDEC, $n^{\circ}$ 38, 1996, pp. 223-238.

. Cidadania Ativa: Referendo, Plebicisto e Iniciativa Popular. SP: Ed. Ática, 2003.

BOAS, R. V. Os Canais Institucionais de Participação Popular. In: BOAS, Renata Villas. et al. (org.) Participação Popular nos Governos Locais, São Paulo: Pólis,1994.

BOBBIO, N. O Futuro da Democracia. São Paulo: Paz e Terra, 2000.

. A Era dos Direitos. Rio de Janeiro: Campus, 1992.

. Liberalismo e Democracia. São Paulo: Ed Brasiliense, 1988.

BOGDAN, R.C. \& BIKLEN, S. K. Investigação Qualitativa em Educação. Porto: Portugal, Ed. Porto: p.43-51,1994.

BRANDÃO C.R. \& STRECK D. R.(org.) Pesquisa Participante: o saber da partilha. 
Aparecida,SP: Idéias \& Letras, 2006.

BRASIL. Constituição (1988). Constituição da República Federativa do Brasil: promulgada em 5 de outubro de 1988. São Paulo: Saraiva, 1990.

CANIVEZ, P. Educar o cidadão?- Campinas, SP: Papirus, 1991.

CARDELLI, J; Duhalde, M e Maffei, L. Educação para o século XXI- SP: Instituto Polis, 2003.

CARNOY, M. Estado e Teoria Política. Campinas, SP: Papirus, 2004.

CARVALHO, M. do C. e FELGUEIRAS, D. Orçamento Participativo no ABC - Mauá, Ribeirão Pires e Santo André. São Paulo: Polis, 2000.

CEPAM. Orçamento Participativo: por uma gestão democrática - mesa técnica realizada em 17/9/1997. São Paulo: FPFL - 1998.

CHAUÍ, M. Cultura e Democracia: o discurso competente e outras falas. São Paulo: Cortez, 1990.

COMPARATO, F.K. A Afirmação Histórica dos Direitos Humanos. São Paulo: Saraiva, 2003.

COUTINHO, C. N. Cidadania, Democracia e Educação.In: Escola: espaço de construção da cidadania. Série IDÉIAS, $n^{\circ}$ 24. São Paulo: Fundação para o desenvolvimento da Educação (FDE), 1994, p. 13-26.

Contra a Corrente: ensaios sobre democracia e socialismo, SP: Cortez, 2000.

DA MATTA, R. A casa \& a Rua. Espaço, Cidadania e morte no Brasil. 5a ed. Rio de Janeiro: Rocco, 1997.

DANIEL, C. Gestão Local e Participação da Sociedade. In: BOAS, Renata Villas. et al. (org.) Participação Popular nos Governos Locais, São Paulo: Pólis,1994.

DEMO, P. Participação é Conquista: noções de política social participativa, SP: Cortez, 1996.

DEWEY, J. Liberalismo, Liberdade e Cultura, SP: Nacional, 1970.

DUTRA ,O. e BENEVIDES, M. V. Orçamento Participativo e Socialismo. São Paulo, Fundação Perseu Abramo, 2001.

FEDOZZI, L. Orçamento Participativo: reflexões sobre a experiência de Porto Alegre. 2 ed. Porto Alegre: Tomo Editorial; Rio de Janeiro: Observatório de Políticas, 1999.

FISCHER, N. B. e MOLL, J. Por uma nova esfera pública: A experiência do Orçamento Participativo. Petrópolis, RJ: Vozes, 2000. 
FREIRE, P. Educação como Prática da Liberdade. RJ: Paz e Terra, 1967. . Pedagogia do Oprimido, RJ: Paz e Terra, 1987.

.Pedagogia da Autonomia: saberes necessários à prática educativa. SP: Paz e Terra, 1996.

. Política e educação: ensaios. SP: Cortez, 2003.

GENRO, T. \& SOUZA, U. Orçamento Participativo: a experiência de Porto Alegre. São Paulo: Fundação Perseu Abramo, 1997.

GOHN, M. Movimentos Sociais e Educação, SP: Cortez, 1994. . Conselhos Gestores e participação sócio política. São Paulo: Cortez, 2001. . Os Conselhos de Educação e a Reforma do Estado. In: Carvalho, M. C. e Teixeira, A. C. et al.(org.) Conselhos Gestores de Políticas Públicas. São Paulo: Polis, 2000.

GOUVEIA, A. B. Orçamento Participativo, Controle Social e o Poder Público Municipal: A Experiência de União da Vitória/PR ( 1997-2000). Dissertação de mestrado. São Paulo: USP, 2002, 132 p.

GRAMSCI, A. Maquiavel, a Política e o Estado Moderno. Rio de Janeiro: Civilização Brasileira, 1984.

HABERMAS, J. Mudança estrutural da esfera pública. RJ: Tempo Brasileiro, 1984.

KERBAUY, M. T. A Morte dos Coronéis: Política Interiorana e Poder Local. Araraquara:FCL/UNESP; SP: Cultura Acadêmica Editora, 2000.

LAFER, C. A Reconstrução dos Direitos Humanos - Um diálogo com o Pensamento de Hannah Arendt. SP: Companhia das Letras, 1988.

LAKATOS, E. M. \& MARCONI, A. Metodologia do Trabalho Científico: procedimentos básicos, pesquisa bibliográfica, projeto e relatório, publicações e trabalhos científico. São Paulo: Atlas, 6a ed., 2001.

LAVILLE, C. \& DIONNE, J. A Construção do Saber: manual de metodologia da pesquisa em ciências humanas. Porto Alegre: Editora Artes Médicas Sul Ltda.; Belo Horizonte: Editora UFMG, 1999.

LIMA, L. Organização Escolar e Democracia Radical: Paulo Freire e a Governação Democrática da Escola Pública. SP: Cortez, 2000.

LOCKE, J. Segundo Tratado Sobre o Governo Civil. Petrópolis, RJ: Vozes, 2006. 
MARX, K. O Capital. Volume I.R.J.: Ed. Bertrand Brasil, 1988.

MARSHALL, T.H. Cidadania, classe social e status. Rio de Janeiro: Zahar, 1957.

MILLS,C.W. A Imaginação Sociológica. Rio de Janeiro:Zahar, 1965.

PARO, V. H. Eleição de Diretores: A Escola Pública Experimenta a Democracia. Campinas, SP: Ed. Papirus, 1996. Por Dentro da Escola Pública. São Paulo: Xamã, 2000 a. . Qualidade de Ensino: A Contribuição dos Pais. São Paulo: Xamã, 2000 b. . Escritos sobre Educação. São Paulo: Xamã, 2001a. - Implicações do Caráter Político da Educação para a administração da Escola Pública. Revista Educação e Pequisa, São Paulo, v. 28, n. 2, jul./dez. 2001b. p.1123. . Políticas Públicas e Educação de Base. São Paulo: Xamã, 2001b. . Gestão Democrática da Escola Pública. São Paulo: Ed. Ática, 2005a. . Administração Escolar: Introdução Crítica. São Paulo: Cortez, 2005b.

PONT, R. Democracia, participação, cidadania: uma visão de esquerda. Porto Alegre, RS: Ed Palmarinca, 2000.

PONTUAL, P. de C. O Processo Educativo no Orçamento Participativo: Aprendizado dos atores da Sociedade Civil e do Estado. Tese de doutorado. São Paulo: PUC, 2000, 281 p. POULANTZAS, N. O Estado, O Poder, O Socialismo. Rio de Janeiro: Graal, 1985. PREFEITURA MUNICIPAL DE ARARAQUARA. Regimento Interno do Orçamento participativo, 2003, mimeografado.

. Relatório sobre a participação no Processo do OP, 2003, mimeo.

RAICHELIS, R. Sistematização: Os Conselhos de Gestão no contexto internacional. In: Carvalho, M. C. e Teixeira, A. C. et al.(org.) Conselhos Gestores de Políticas Públicas. São Paulo: Polis, 2000.

RODRIGUES, L. M. Sindicalismo e Classe Operária (1930-1964) In: Gomes, A. et. al. O Brasil Republicano, V. 3: Sociedade e Política (1930-1964). RJ: Bertrand Brasil, 2004 ROUSSEAU, J. J. o Contrato Social. São Paulo: Nova Cultural, 1997.

SADER, E. Quando novos personagens entraram em cena. Experiências, falas e lutas dos trabalhadores da grande São Paulo ( 1970- 80). São Paulo: Paz e Terra, 1995.

SANCHES, F. Orçamento Participativo: teoria e prática. São Paulo: Cortez, 2002. 
SANTOS, B. S. Orçamento Participativo em Porto Alegre: para uma democracia redistributiva. In: SANTOS, B. De S. [org.] Democratizar a Democracia: Os Caminhos da Democracia Participativa. Rio de Janeiro: Civilização Brasileira, 2002.

SPÓSITO, M. P. Educação, Gestão Democrática e Participação Popular. In: Bastos, J. B. et. al. (org). Gestão Democrática. RJ: DP\&A: SEPE, 1999

TELLES, V. Sociedade Civil, Direitos e Espaços Públicos. In: Boas, Renata Villas. et al. (org.) Participação Popular nos Governos Locais, São Paulo: Pólis,1994.

VILAS-BOAS, R. Os Canais Institucionais de Participação Popular. In: Boas, Renata Villas. et al. (org.) Participação Popular nos Governos Locais, São Paulo: Pólis,1994. 
Anexos: 
Anexo A - Lei de alteração dos artigos $9^{\circ}$ e 10 da Lei Municipal $n^{\circ}$ 4.947, do Conselho Municipal de Educação. 


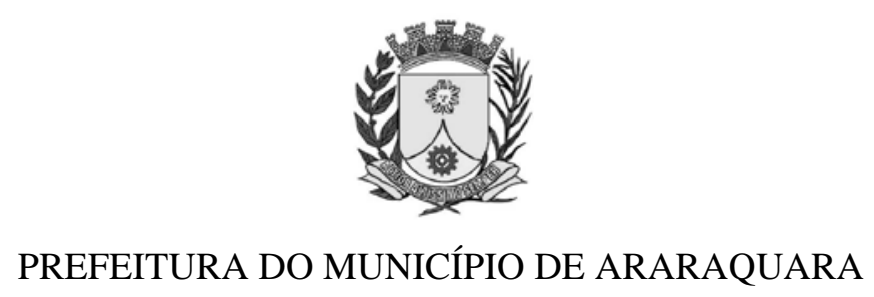

LEI No 5.658

De 29 de agosto de 2001

Dispõe sobre alteração dos artigos $9^{\circ}$ e 10 da Lei Municipal $n^{\circ} 4.947$, de 27 de novembro de 1997, que criou o Conselho Municipal de Educação.

\section{O PREFEITO DO MUNICÍPIO DE ARARAQUARA,}

Estado de São Paulo, no exercício de suas atribuições legais, e de acordo com o que aprovou a Câmara Municipal, em sessão ordinária de 14 de agosto de 2001, promulga a seguinte lei:

Artigo $1^{\circ}$ - Os Artigos $9^{\circ}$ e 10 da Lei Municipal no 4.947, de 27 de novembro de 1997, que dispõe sobre a criação do Conselho Municipal de Educação, passam a ter a seguinte redação:

“ Artigo 90 - O Conselho Municipal de Educação será composto por 33 (trinta e três) membros, escolhidos entre pessoas com experiência ou que possuam definido interesse em matéria educacional ou ainda de reconhecida dedicação às atividades educacionais no Município, observada a devida representação das diversas modalidades de ensino e a participação de representantes do ensino público e privado, bem como de entidades da comunidade em geral.

\section{Parágrafo Único -}

Artigo 10 - O Conselho Municipal de Educação terá a seguinte composição: 
I - O Secretário Municipal de Educação;

II - 1 (um) representante da Coordenadoria de Participação Popular do Município;

III - 1 (um) representante do Conselho do Fundef;

IV - 1 (um) representante do Conselho de Alimentação Escolar;

V - 1 (um) representante da Secretaria Municipal de Educação;

VI - 1 (um) representante da Secretaria Municipal de Cultura;

VII - 1 (um) representante da Secretaria Municipal de Esportes e Lazer;

VIII - 1 (um) representante da Secretaria Municipal de Assistência Social;

IX - 1 (um) representante da Secretaria Municipal de Saúde;

X - 1 (um) representante do magistério público municipal;

XI - 1 (um) representante do magistério público estadual;

XII - 1 (um) representante do magistério da rede particular de ensino;

XIII - 1 (um) representante dos diretores das escolas municipais de Araraquara;

XIV - 1 (um) representante dos diretores das escolas estaduais de Araraquara;

XV - 1 (um) representante dos diretores do ensino privado;

XVI - 1 (um) representante dos professores aposentados da cidade de Araraquara;

XVII - 2 (dois) representantes dos pais de alunos das escolas públicas municipais (indicado pelos Conselhos de Escola do Município);

XVIII - 1 (um) representante da Diretoria Regional de Ensino;

XIX - 1 (um) representante dos pais de alunos das escolas públicas estaduais;

XX - 1 (um) representante dos pais de alunos das escolas particulares;

XXI - 1 (um) representante das entidades estudantis do Município;

XXII - 1 (um) representante da Educação Especial oferecida no Município;

XXIII - 1 (um) representante dos servidores do quadro de apoio da educação municipal;

XXIV - 1 (um) representante dos servidores do quadro de apoio da educação estadual;

XXV - 1 (um) representante do ensino superior público de Araraquara;

XXVI - 1 (um) representante do ensino superior privado de Araraquara;

XXVII - 1 (um) representante das escolas técnicas do Município;

XXVIII - 1 (um) representante das entidades de classe do magistério público;

XXIX - 1 (um) representante dos sindicatos dos trabalhadores da cidade de Araraquara;

XXX - 1 (um) representante do sindicato dos funcionários municipais;

XXXI - 2 (dois) representantes da Câmara Municipal.” 
Artigo $\mathbf{2}^{\mathbf{0}}$ - Esta Lei entrará em vigor na data de sua publicação.

Artigo $3^{\mathbf{0}}$ - Revogam-se as disposições em contrário.

PREFEITURA DO MUNICÍPIO DE ARARAQUARA, aos 29 (vinte e nove) dias do mês de agosto do ano de 2001 (dois mil e um).

\section{EDSON ANTONIO DA SILVA}

- Prefeito Municipal -

Publicada na Secretaria Municipal de Governo, na data supra.

\section{CLÉLIA MARA SANTOS FERRARI}

- Secretária de Governo -

Arquivada em livro próprio nº 01/2001. (“PC”). 
Anexo B - Lei de Criação dos Conselhos de Escola 


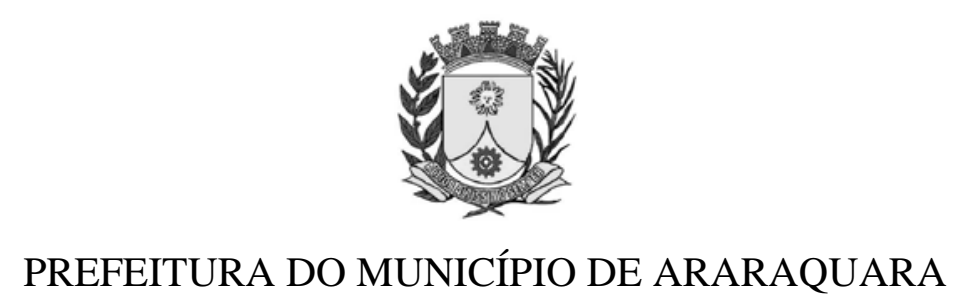

\section{LEI $N^{\circ} 5.785$}

De 25 de março de 2002

Institui o Conselho de Escola nas Unidades

Escolares do Município de Araraquara e dá outras providências.

\section{O PREFEITO DO MUNICÍPIO DE ARARAQUARA,}

Estado de São Paulo, no exercício de suas atribuições legais, e de acordo com o que aprovou a Câmara Municipal, em sessão ordinária de 21 de março de 2002, promulga a seguinte lei:

\section{CAPÍTULO I DISPOSIÇÕES GERAIS}

Artigo $1^{\circ}$ - Fica instituído o Conselho de Escola, como espaço de decisões de cada unidade escolar do Município, de acordo com o Artigo 205, do Capítulo III da Constituição da República Federativa do Brasil, promulgada em 05 de outubro de 1988 e do Artigo 14, inciso II, da Lei Federal nº 9.394/96 - Lei de Diretrizes e Bases da Educação Nacional - LDB.

Artigo $\mathbf{2}^{\mathbf{0}}$ - Cabe ao Poder Executivo Municipal, por todos os meios ao seu alcance, subsidiar a atuação dos Conselhos de Escola estabelecida por esta Lei.

\section{CAPÍTULO II}




\section{DOS OBJETIVOS}

Artigo $3^{\circ}$ - O Conselho de Escola terá como objetivos:

I - Democratizar as relações de poder no interior da escola, priorizando a representação e garantindo o poder de decisão de todos os segmentos da comunidade escolar;

II - Garantir o interesse de todos, propiciando espaços de informação, respeitando o pluralismo de idéias, as regras do jogo democrático, e estimulando a relação entre administração e população, de forma a assegurar a eficiência do processo; e, III - Contribuir para que a escola alcance progressivos graus de autonomia no campo pedagógico, administrativo e financeiro.

\section{CAPÍTULO III}

DA NATUREZA

Artigo $4^{\mathbf{0}}$ - O Conselho de Escola é o órgão máximo de decisão da Unidade Escolar, de natureza deliberativa, consultiva, normativa e fiscalizadora.

\section{CAPÍTULO IV}

\section{DA COMPOSIÇÃO}

Artigo $5^{\mathbf{0}}$ - O Conselho de Escola terá o número de membros fixado a critério da escola, e respeitadas suas características, será paritário, assegurada a proporcionalidade de 50\% (cinqüenta por cento) para representantes da população usuária, distribuídos entre os segmentos de pais ou responsáveis, alunos e comunidade local, e 50\% (cinqüenta por cento) para o Poder Público, distribuídos entre os segmentos membros do magistério, funcionários da Unidade de Ensino e direção da escola.

§ $\mathbf{1}^{\mathbf{0}}$ - O diretor da Unidade integrará o Conselho de Escola como membro nato, fazendo parte dos 50\% da representação do Poder Público no referido colegiado. 
$\S \mathbf{2}^{\mathbf{0}}$ - A comunidade local onde a escola está inserida, será representada por uma de suas lideranças preocupadas com a educação.

§ $\mathbf{3}^{\mathbf{0}}$ - Não havendo candidato da comunidade local, sua vaga será preenchida por um representante de pais ou responsáveis legais, ou por um representante dos alunos.

§ $\mathbf{4}^{\mathbf{0}}$ - Não havendo candidatos para representação dos alunos, as vagas serão preenchidas por representantes de pais ou responsáveis legais.

§ $\mathbf{5}^{\mathbf{0}}$ - Os funcionários das escolas poderão participar do Conselho apenas como representantes do Poder Público, sendo vedado aos mesmos representar, na unidade escolar de atuação, qualquer dos segmentos da população usuária.

§ $6^{0}$ - A função de membro do Conselho de Escola não será remunerada.

$\S \mathbf{7}^{\mathbf{0}}$ - Exclusivamente em Unidades Escolares onde o Município mantém parceria / convênio com Entidades, Associações e Fundações, esta terá assento no Conselho de Escola, devidamente representada por membros indicados pela Entidade, na proporção de 1/3 do total de membros, sendo os outros 2/3 representados pelo Poder Público e pela Comunidade Local, respeitada a mesma proporção.

\section{CAPITULO V}

\section{DAS ATRIBUIÇÕES E COMPETÊNCIAS}

Artigo $6^{\circ}$ - São competências do Conselho de Escola:

I - Participar da formulação de prioridades e metas de ação da escola, que deverão orientar a elaboração da proposta pedagógica e do Plano Escolar, bem como da sua homologação; II - Deliberar, acompanhar e fiscalizar a execução do Plano da Unidade Escolar; III - Participar do processo de identificação dos custos do Plano Escolar, bem como da elaboração do Orçamento da Cidade, nas plenárias temáticas de Educação; IV - Debater e deliberar sobre os problemas não previstos no Plano da Unidade Escolar e que envolvam a Unidade Escolar;

V - Avaliar o desempenho da escola face às diretrizes, prioridades e metas estabelecidas no Plano Escolar, a partir das normas da Secretaria de Educação consubstanciadas nas diretrizes do Plano Municipal de Educação; 
VI - Decidir a organização e funcionamento da escola, de acordo com a orientação da Secretaria Municipal de Educação sobre:

a) Atendimento e acomodação das demandas, turnos, distribuição de série e classes, utilização do espaço físico.

b) A fixação de critérios para a construção, adequação, reforma e ocupação do prédio e suas instalações, condição para sua preservação, cessão para outras atividades que não do ensino e de interesse da comunidade.

c) Análise, aprovação e acompanhamento de projetos propostos pelos professores e pela comunidade.

d) Regulamentação dos organismos auxiliares que venham a ser criados.

VII - Analisar os problemas relacionados com a demanda e evasão escolar, bem como contribuir para a superação dos mesmos;

VIII - Discutir e definir critérios e procedimentos de avaliação, relativos ao trabalho educativo e de todos os envolvidos nas ações educacionais;

IX - Deliberar, gerir e fiscalizar a utilização e priorização de recursos sob responsabilidade da escola;

$\mathbf{X}$ - Decidir sobre os procedimentos relativos à integração com outros equipamentos públicos, instituições, organizações da sociedade em seu âmbito local, em conformidade com a política da Secretaria de Educação;

XI - Indicar ou sugerir nomes que integrarão o Fórum Municipal de Educação;

XII - Homologar o nome do eleito à Diretor de Escola, quando a ocupação desse cargo for em caráter emergencial;

XIII - Homologar a escolha do Vice-Diretor e do Professor Coordenador, no âmbito da Unidade Escolar;

XIV - Elaborar e aprovar normas próprias de funcionamento, um calendário de reuniões e delegar atribuições às Comissões, com finalidade de dinamizar sua atuação e facilitar sua organização;

XV - Debater e aprovar o Regimento da Escola em consonância com a normatização ou orientação advindas da Secretaria de Educação ou do Conselho Municipal de Educação; XVI - Apresentar periódica e sistematicamente, informações sobre o uso dos recursos financeiros, a qualidade dos serviços prestados e os resultados obtidos, bem como divulgar tais informações à Comunidade; 
XVII - Tornar públicas e dar ampla divulgação a todas as suas ações e deliberações, imediatamente, através de murais, boletins, jornais locais, rádios comunitárias, reuniões ou assembléias gerias, para prestação de contas;

XVIII - Convocar Assembléias Gerais Ordinárias, no mínimo 02 (duas) vezes ao ano e Assembléias Extraordinárias quando for necessário para:

a) Apresentação ou avaliação do Plano da Escola;

b) Prestação de contas dos trabalhos do Conselho;

c) Tratar de assuntos gerais que julguem necessários;

d) Debater temas polêmicos, sempre que dividirem a opinião da comunidade escolar ou que ferem algum tipo de direito das crianças e dos adolescentes.

XIX - Divulgar com antecedência a data e o horário das reuniões e assembléias;

XX - Buscar intercâmbio e integração com outros Conselhos existentes no Município, escolares ou não, especialmente com o Conselho Municipal de Educação;

XXI - Analisar a substituição de conselheiros em casos de perda de mandato, abuso de poder ou renúncia, de acordo com o previsto no Regimento Interno.

Parágrafo Único - Os casos de substituição e perda de mandato dos conselheiros deverão estar previstos no Regimento Interno do Conselho de Escola.

\section{CAPÍTULO VI}

\section{DAS DELIBERAÇÕES DO CONSELHO DE ESCOLA}

Artigo $7^{\mathbf{0}}$ - As reuniões do Conselho de Escola serão instaladas, em primeira convocação, com a presença da maioria simples dos membros e, em segunda convocação, após 30 minutos, com qualquer número de membros.

Artigo $8^{\circ}$ - As deliberações do Conselho de Escola dar-se-ão por maioria simples de votos, sendo lavradas em ata e tornadas públicas, no prazo máximo de 15 (quinze) dias.

Parágrafo Único - A nenhum membro do Conselho de Escola será permitido o acúmulo de voto, nem o voto por procuração. 
Artigo $9^{\circ}$ - As reuniões do Conselho de Escola serão públicas e abertas, tendo todos os participantes direito a voz.

\section{CAPÍTULO VII \\ DA ELEIÇÃO DO CONSELHO DE ESCOLA}

Artigo 10 - Os integrantes do Conselho de Escola serão eleitos, por seus pares, a cada início do ano letivo, mediante processo eletivo direto, com mandato de um ano, com direito a uma reeleição.

$\S \mathbf{1}^{\mathbf{0}}$ - Cada segmento integrante do Conselho de Escola elegerá também um suplente, que substituirá o membro efetivo em sua ausência ou impedimento.

$\S \mathbf{2}^{\mathbf{o}}$ - O representante da comunidade local deverá ser eleito em plenária específica, convocada para esse fim, com as organizações ou entidades da região, convocada pela direção da escola.

$\S \mathbf{3}^{\mathbf{o}}$ - O representante dos alunos no Conselho de Escola deverá ter idade mínima de 12 (doze) anos para ter direito à voz e, desde que não haja nenhum impedimento legal, também direito a voto.

Artigo 11 - O processo que elegerá o Conselho de Escola será conduzido por comissão eleitoral, escolhida pelo Conselho de Escola e, na falta deste, pela Assembléia Geral, especialmente composta para este fim, que deverá iniciar seus trabalhos no prazo mínimo de dois meses antes do final do mandato dos membros do Conselho de Escola.

Artigo 12 - A Comissão eleitoral será composta por:

I - Diretor da unidade escolar;

II - Pelo menos 4 representantes dos segmentos que compõem o Conselho.

Parágrafo Único - A Comissão Eleitoral elegerá seu presidente dentre os membros que a compõem, maiores de 16 anos, o que deverá ser registrado em ata, bem como os demais trabalhos pertinentes ao processo eleitoral. 
Artigo 13 - A Comissão Eleitoral convocará os segmentos que elegerão os representantes para o Conselho de Escola através de edital e outras formas de divulgação, com antecedência de 15 (quinze) dias.

\section{CAPÍTULO VIII}

\section{DAS DISPOSIÇÕES TRANSITÓRIAS}

Artigo 14 - Às Unidades Escolares que elegeram os seus Conselhos antes da aprovação e publicação desta lei, fica garantida a decisão de permanecer nas condições em que foram constituídos, até as próximas eleições, adequar-se ou convocar novas eleições, a partir do novo ano letivo, de acordo com esta legislação.

Artigo 15 - Esta lei entrará em vigor na data de sua publicação, revogadas as disposições em contrário.

PREFEITURA DO MUNICÍPIO DE ARARAQUARA, aos 25 (vinte e cinco) dias do mês de março do ano de 2002 (dois mil e dois).

\section{EDSON ANTONIO DA SILVA}

- Prefeito Municipal -

Publicada na Secretaria Municipal de Governo, na data supra.

\section{CLÉLIA MARA SANTOS FERRARI}

- Secretária de Governo -

Arquivada em livro próprio nº 01/2002. (“PC”) 
Anexo C: Lei que reformula o Conselho Municipal de Saúde 


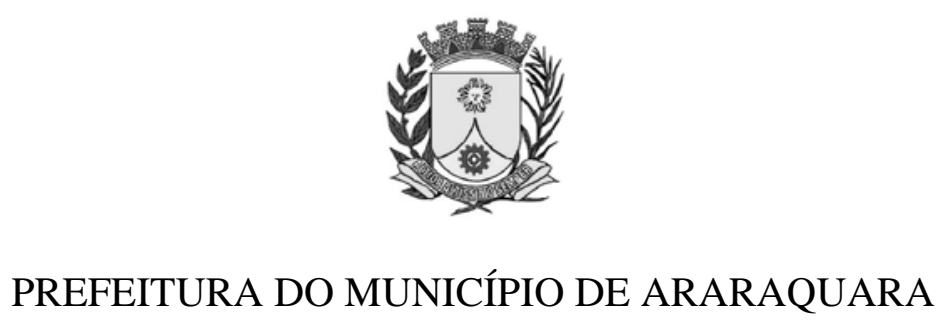

LEI $N^{\circ} 6.264$

De 02 de junho de 2005

Reformula o Conselho Municipal de Saúde de Araraquara e dá outras providências.

O PREFEITO DO MUNICÍPIO DE ARARAQUARA, Estado de São Paulo, no exercício de suas atribuições legais, e de acordo com o que aprovou a Câmara Municipal, em sessão ordinária de 31 de maio de 2005, promulga a seguinte lei:

\section{CAPÍTULO I \\ DA INSTITUIÇÃO}

Art. $1^{0}$ Em conformidade com a Constituição da República Federativa do Brasil, Título VIII, Capítulo II e as Leis Federais nºs 8.080/90 e 8142/90, fica reformulado o Conselho Municipal de Saúde de Araraquara, órgão permanente, deliberativo, propositivo e normativo do Sistema Único de Saúde no âmbito municipal, que tem por competência elaborar estratégias e controlar a execução da política de saúde do município, inclusive nos seus aspectos econômicos e financeiros.

\section{Capítulo II}

\section{DAS COMPETÊNCIAS DO CONSELHO MUNICIPAL DE SAÚDE}

Art. $2^{\mathbf{0}}$ Ao Conselho Municipal de Saúde de Araraquara, consoante o disposto na legislação federal, compete:

I - Implementar a mobilização e articulação contínuas da sociedade, na defesa dos princípios constitucionais que fundamentam o SUS, para o controle social de saúde;

II - Elaborar o Regimento Interno do Conselho e outras normas de funcionamento; 
III - Discutir, elaborar e aprovar proposta de operacionalização das diretrizes aprovadas pelas Conferências de Saúde;

IV - Atuar na formulação e no controle da execução da política de saúde, incluindo os seus aspectos econômicos e financeiros e propor estratégias para a sua aplicação aos setores público e privado;

V - Definir diretrizes para elaboração dos planos de saúde e sobre eles deliberar, conforme as diversas situações epidemiológicas e a capacidade organizacional dos serviços;

VI - Estabelecer estratégicas e procedimentos da gestão do SUS, articulando-se com os demais colegiados como os de seguridade, meio ambiente, justiça, educação, trabalho, agricultura, idosos, criança e adolescente e outros;

VII - Proceder à fiscalização periódica dos planos de saúde, respeitadas as normas de direito privado;

VIII - Deliberar sobre os programas de saúde e aprovar projetos a serem encaminhados ao Poder Legislativo, propor a adoção de critérios definidores de qualidade e resolutividade, atualizando-os em face do processo de incorporação dos avanços científicos e tecnológicos, na área da saúde;

IX - Estabelecer diretrizes e critérios operacionais relativos à localização e ao tipo de unidades prestadoras de serviços de saúde públicos e privados, no âmbito do SUS, tendo em vista o direito ao acesso universal às ações de promoção, proteção e recuperação da saúde em todos os níveis de complexidade dos serviços, sob a diretriz da hierarquização/regionalização da oferta e demanda de serviços, conforme o princípio da eqüidade;

X - Avaliar, explicitando os critérios utilizados, a organização e o funcionamento do Sistema Único de Saúde - SUS;

XI - Avaliar os contratos e convênios, conforme as diretrizes dos Planos de Saúde Nacional, Estaduais, do Distrito Federal e Municipais;

XII - Aprovar a proposta orçamentaria anual da saúde, tendo em vista as metas e prioridades estabelecidas na Lei de Diretrizes Orçamentarias (artigo $195 \S 2^{\circ}$ da Constituição Federal), observado o princípio do processo de planejamento e orçamentação ascendentes (artigo 36 da Lei Federal n 8.080/90);

XIII - Propor critérios para programação e execução financeira e orçamentaria dos Fundos de Saúde e acompanhar a movimentação e destinação dos recursos;

XIV - Fiscalizar e controlar gastos e deliberar sobre critérios de movimentação de recursos da Saúde, incluindo o Fundo de Saúde e os transferidos e próprios do Município, Estado, Distrito Federal e da União; 
XV - Analisar, discutir e aprovar o relatório de gestão, com a prestação de contas e informações financeiras, repassadas em tempo hábil aos conselheiros, acompanhando do devido assessoramento;

XVI - Fiscalizar e acompanhar o desenvolvimento das ações e dos serviços de saúde e encaminhar as eventuais denúncias aos respectivos órgãos, conforme legislação vigente;

XVII - Examinar propostas e denúncias de indícios de irregularidades, responder no seu âmbito a consultas sobre assuntos pertinentes às ações e aos serviços de saúde, bem como apreciar recursos a respeito de deliberações do Conselho, nas suas respectivas instâncias;

XVIII - Estabelecer critérios para a determinação de periodicidade das Conferências de Saúde, propor sua convocação, estruturar a comissão organizadora, submeter o respectivo regimento e programas ao Pleno do Conselho de Saúde correspondente, explicitando deveres e papéis dos conselheiros nas pré-conferências de saúde;

XIX - Estimular articulação e intercâmbio entre os conselheiros de Saúde e entidades governamentais e privadas, visando à promoção da Saúde;

XX - Estimular, apoiar e promover estudos e pesquisas sobre assuntos e temas na área de saúde pertinentes ao desenvolvimento do Sistema Único de Saúde - SUS;

XXI - Estabelecer ações de informação, educação e comunicação em saúde e divulgar as funções e competências do Conselho de Saúde, seus trabalhos e decisões por todos os meios de comunicação, incluindo informações sobre as agendas, datas e local das reuniões;

XXII - Apoiar e promover a educação para controle social. Constarão do conteúdo programático os fundamentos teóricos da saúde, a situação epidemiológica, a organização do SUS, a situação real de funcionamento dos serviços do SUS, as atividades e competências do Conselho de Saúde, bem como a Legislação do SUS, suas políticas de saúde, orçamento e financiamento;

XXIII - Propor e avaliar a política de Recursos Humanos do SUS;

XXIV - Acompanhar a implementação das deliberações constantes do relatório das plenárias dos Conselhos de Saúde;

XXV - Acompanhar e assessorar os Conselhos Gestores das Unidades de Saúde no cumprimento de seus objetivos, conforme dispõe a Lei n 5.655, de 24/08/2001.

\section{Capítulo III DA CONSTITUIÇÃO}

Art. $3^{\circ}$ O Conselho Municipal de Saúde terá a seguinte constituição:

I - Segmentos organizados de usuários do Sistema Único de Saúde; 
II - Entidades dos trabalhadores da Saúde;

III - Prestadores de serviços de saúde do Sistema Único de Saúde; e,

IV - Representantes do governo municipal.

Parágrafo único. A representação dos usuários será paritária em relação ao conjunto dos demais segmentos.

Art. 4 ${ }^{\mathbf{0}}$ O Conselho Municipal de Saúde terá uma Mesa Diretora como órgão operacional de execução e implementação de suas decisões sobre o Sistema Único de Saúde do Município, eleita na forma do art. $6^{\circ}$ desta Lei.

composição:

Art. $5^{\circ}$ O Conselho Municipal de Saúde terá a seguinte

I - De forma paritária e quadripartite, escolhidos por voto direto dos delegados de cada segmento na conferência Municipal de Saúde, as representações no conselho serão assim distribuídos:

a). 18 (dezoito) representantes dos segmentos organizados de usuários do Sistema Único de Saúde;

b). 9 (nove) representantes de entidades dos trabalhadores de Saúde;

c). 5 (cinco) representantes de prestadores de serviço de saúde do Sistema Único de Saúde Municipal;

d). 4 (quatro) representantes do Poder Executivo, indicados pelo Prefeito Municipal;

II - A representação paritária de que trata este artigo será realizada de forma direta junto aos delegados representantes dos segmentos, que participarão da Conferência Municipal de Saúde;

III - Para garantir o princípio legal da paridade e para não comprometer a sua atuação, os representantes dos usuários não devem ter vínculos diretos com pessoas ou cargos no governo, com trabalhadores de saúde, com os prestadores de serviço ou com outros segmentos já contemplados na composição do CMS;

IV - Cada segmento representado do conselho terá um suplente, eleito na Conferência Municipal de Saúde;

V - Um mesmo segmento poderá ocupar no máximo duas vagas no Conselho Municipal de Saúde;

VI - A presidência do Conselho Municipal de Saúde será atribuída ao conselheiro eleito pela plenária do Conselho. 
Art. $6^{\circ}$ A mesa Diretora, referida no artigo $4^{\circ}$ desta Lei, será eleita diretamente pela Plenária do Conselho e será composta de:

I - Presidente;

II - Vice-Presidente;

III - Secretário; e

IV - Vice-Secretário.

Art. $7^{\circ} \mathrm{O}$ Conselho Municipal de Saúde reger-se-á pelas seguintes disposições, no que se refere a seus membros:

I - Serão indicados pelos seus respectivos segmentos e serão substituídos pelos mesmos mediante solicitação ao Prefeito através da Mesa Diretora do Conselho;

II - Terão seu mandato extinto, caso faltem, sem prévia justificação, a 3 (três) reuniões consecutivas ou 6 (seis) intercaladas, num período de 12 (dose) meses;

III - Terão mandato de 2 (dois) anos, cabendo prorrogação ou recondução, porém na primeira eleição o mandato será, excepcionalmente, de 3 (três) anos;

IV - Cada entidade participante terá um suplente, conforme disposto no item III do Art. $5^{\circ}$ desta Lei.

Parágrafo único. O exercício do mandato de membro do Conselho Municipal de Saúde não será remunerado e será considerado de alta relevância pública.

Art. $8^{\mathbf{0}}$ Para melhor desempenho de suas funções, o Conselho Municipal de Saúde poderá recorrer a pessoas e entidades, mediante os seguintes critérios:

I - Consideram-se colaboradores do Conselho Municipal, as instituições formadoras de recursos humanos para a saúde e as entidades representativas de profissionais e usuários de saúde, independentemente de sua condição de membros;

II - Poderão ser convidadas pessoas ou instituições de notória especialização na área de saúde, para assessorar o Conselho em assuntos específicos.

III - Poderão ser criadas comissões internas entre as instituições, entidades e membros do Conselho, para promover estudos e emitir pareceres a respeito de temas específicos.

\section{Capítulo IV}

\section{DO FUNCIONAMENTO E CONVOCAÇÃO}

Art. $9^{\circ}$ O Conselho Municipal de Saúde funcionará segundo o que disciplina o seu Regimento Interno e terá as seguintes normas gerais: 
I - O órgão de deliberação máxima será a Plenária do Conselho;

II - A plenária do Conselho reunir-se-á ordinariamente uma vez por mês e extraordinariamente, quando convocada pelo Presidente ou pela maioria simples de seus membros;

III - O Conselho Municipal de Saúde reunir-se-á extraordinariamente para tratar de matérias especiais ou urgentes, quando houver:

a) Convocação formal da Mesa Diretora;

b) Convocação formal de metade, mais um de seus membros titulares.

IV - Cada membro do Conselho terá direito a um único voto na Plenária do Conselho;

V - As Plenárias do Conselho serão instaladas com a presença da maioria simples dos membros ou, em segunda chamada, após 30 minutos, com no mínimo 1/4 (um quarto) dos presentes;

VI - As decisões do Conselho Municipal de Saúde serão consubstanciadas em resolução, moção ou recomendação.

VII - As decisões da Mesa Diretora deverão, na sessão seguinte, ser apresentadas à Plenária do Conselho para deliberação.

Art. 10. O Conselho Municipal de Saúde convocará pelo menos a cada quatro anos, uma Conferência Municipal de Saúde para avaliar a política municipal de saúde, propor diretrizes de ação para o Sistema Único de Saúde e efetuar a eleição dos representantes do conselho.

\section{Capítulo V}

\section{DAS DIRETRIZES BÁSICAS DA ATUAÇÃO}

Art. 11. O Conselho Municipal de Saúde observará no exercício de sua atribuições, as seguinte diretrizes básicas e prioritárias:

I - A saúde é direito de todos e dever do Estado, garantido mediante políticas sociais e econômicas que visem à promoção da saúde, redução do risco de doenças e de outros agravos, e ao acesso universal e igualitário às ações e serviços para sua promoção, proteção, recuperação e reabilitação.

II - Integralidade de serviços de saúde, buscando promoção da saúde em toda a rede municipal, diminuindo as taxas de mortalidade infantil e aumentando a expectativa de vida. 
Art. 12. O Conselho Municipal de Saúde promoverá como órgão colegiado deliberativo e representativo, debates estimulando a participação comunitária, visando prioritariamente, a melhoria de serviços de saúde no Município.

Art. 13. As disposições desta Lei, quando necessário, serão regulamentadas pelo Poder Executivo.

Art. 14. Esta Lei entrará em vigor na data de sua publicação, revogadas as disposições em contrário.

PREFEITURA DO MUNICÍPIO DE ARARAQUARA, aos 02 (dois) dias do mês de junho do ano de 2005 (dois mil e cinco).

\section{EDSON ANTONIO EDINHO DA SILVA}

Prefeito Municipal

DR. WAGNER CORRÊA

Secretário dos Negócios Jurídicos

Publicada na Secretaria Municipal de Governo, na data supra.

\section{MÁRCIA APARECIDA OVEJANEDA LIA}

Secretária de Governo

Arquivada em livro próprio nº 01/2005. (“PC”). 
Anexo D: Lei que institui os Conselhos Gestores das Unidades de Saúde do Município de Araraquara e dá outras providências. 


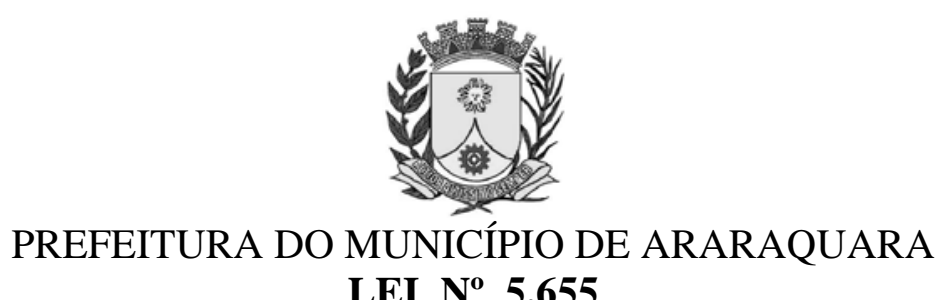

LEI $\mathbf{N}^{\circ} \mathbf{5 . 6 5 5}$

De 24 de agosto de 2001

Institui os Conselhos Gestores das Unidades de Saúde

do Município de Araraquara e dá outras providências.

O PREFEITO DO MUNICÍPIO DE ARARAQUARA,

Estado de São Paulo, no exercício de suas atribuições legais, e de acordo com o que aprovou a Câmara Municipal, em sessão ordinária de 21 de agosto de 2001, promulga a seguinte lei:

\section{CAPÍTULO I \\ DISPOSIÇÕES GERAIS}

Artigo $\mathbf{1}^{\mathbf{0}}$ - Ficam instituídos os Conselhos Gestores das Unidades de Saúde, como órgãos assessores e colegiados, e hierarquicamente subordinados ao Conselho Municipal de Saúde, tendo como finalidade assegurar a participação da comunidade na definição das prioridades das unidades de saúde, de acordo com a permissão contida no Artigo 198, Inciso III, da Constituição Federal.

Artigo $\mathbf{2}^{\mathbf{0}}$ - Cabe ao Poder Executivo Municipal subsidiar amplamente a atuação dos Conselhos Gestores das Unidades de Saúde, estabelecidos por esta lei.

]

\section{CAPÍTULO II \\ DOS OBJETIVOS}

terão por objetivo:

Artigo $3^{\mathbf{0}}$ - Os Conselhos Gestores das Unidades de Saúde I - Participar da elaboração do planejamento anual da sua unidade de saúde, bem como da adaptação dos programas à realidade da região; 
II - Acompanhar o desenvolvimento das diretrizes estabelecidas;

III - Incentivar a população a utilizar os serviços públicos de saúde;

IV - Participar da avaliação da qualidade do atendimento e propor mudanças;

V - Participar da avaliação mensal dos relatórios de produção e do desempenho das unidades de saúde, tanto do ponto de vista qualitativo como quantitativo;

VI - Acompanhar o desenvolvimento dos programas de saúde;

VII - Divulgar ações de interesse da comunidade;

VIII - Aprovar seu Regimento Interno, respeitadas as deliberações do Conselho Municipal de Saúde;

IX - Participar da análise dos indicadores de saúde correspondentes à sua área de atuação;

$\mathbf{X}$ - Proceder ao encaminhamento e execução de todas as providências, recomendações e decisões exaradas pelo Conselho Municipal de Saúde.

\section{CAPÍTULO III}

DA NATUREZA

Artigo $4^{0}$ - O Conselho Gestor da Unidade de Saúde é o órgão de decisão da Unidade de Saúde, de natureza consultiva e fiscalizadora.

\section{CAPÍTULO IV \\ DA COMPOSIÇÃO}

Artigo $5^{0}$ - O Conselho Gestor da Unidade de Saúde terá o número de membros fixado a critério da unidade de saúde e respeitadas suas características, assegurada a paridade de $50 \%$ (cinqüenta por cento) para representantes da população, entre os usuários do SUS - Sistema Único de Saúde, e 50\% (cinqüenta por cento) para os servidores municipais da respectiva unidade.

§ $\mathbf{1}^{\mathbf{0}}$ - O encarregado técnico da unidade de saúde integrará o Conselho como membro nato, fazendo parte dos $50 \%$ (cinqüenta por cento) da representação dos servidores municipais no referido colegiado. 
$\S \mathbf{2}^{\mathbf{0}}$ - Os funcionários das unidades de saúde poderão participar do conselho apenas como representantes do Poder Público, sendo vedado aos mesmos representar quaisquer dos segmentos da população usuária.

$\S \mathbf{3}^{\mathbf{o}}$ - Cada membro titular deverá ter seu respectivo suplente, igualmente eleito pelo segmento que represente.

§ $\mathbf{4}^{\mathbf{0}}$ - A função de membro do Conselho Gestor não será

remunerada.

\section{CAPÍTULO V DAS ATRIBUIÇÕES}

Artigo $6^{0}$ - São atribuições dos Conselhos Gestores:

I - Participar da formulação de prioridades e metas de ação da unidade, que deverão orientar a elaboração do planejamento anual, bem como a adaptação dos programas de saúde à realidade da região, sempre respeitando as determinações da Secretaria Municipal de Saúde e do Conselho Municipal de Saúde;

II - Acompanhar e fiscalizar a execução das prioridades e metas da unidade;

III - Participar do processo de identificação dos custos das prioridades e programas da saúde, bem como da elaboração do orçamento do município, por intermédio do Orçamento Participativo - Plenárias Temáticas da Saúde;

IV - Participar das deliberações para solução dos problemas não previstos no plano de prioridades e metas da unidade;

V - Participar da avaliação do desempenho da unidade face ao plano de prioridades, metas e programas, a partir de normas da Secretaria Municipal de Saúde;

VI - Participar das decisões sobre a organização e funcionamento da unidade;

VII - Participar da análise dos problemas relacionados com a demanda da unidade, bem como contribuir para a superação dos mesmos;

VIII - Elaborar e aprovar normas próprias de funcionamento e um calendário de reuniões do Conselho, com finalidade de dinamizar sua atuação e facilitar sua organização;

IX - Aprovar o Regimento Interno da Unidade em consonância com a normatização ou orientação advinda da Secretaria de Saúde ou do Conselho Municipal de Saúde; 
$\mathbf{X}$ - Buscar periódica e sistematicamente informações sobre o uso dos recursos financeiros, a qualidade dos serviços prestados e os resultados obtidos, bem como divulgar tais informações à comunidade, no âmbito de atuação do respectivo Conselho;

XI - Tornar públicas e dar ampla divulgação de todas as suas ações e deliberações, imediatamente, através de murais, boletins, jornais locais, rádios comunitárias, reuniões ou assembléias gerais, para prestação de contas à comunidade;

XII - Convocar assembléias gerais ordinárias uma vez por mês e extraordinárias sempre que for necessário;

XIII - Divulgar com antecedência a data e o horário das reuniões e assembléias;

XIV - Buscar intercâmbio e integração com os Conselhos Gestores das demais Unidades;

XV - Integrar, representativamente, o Conselho Municipal de Saúde, resguardada a composição paritária do mesmo, por um membro titular e um suplente, escolhidos dentre todos os Conselhos Gestores de Unidades;

XVIII - Analisar a substituição de conselheiros em caso de perda de mandato, abuso de poder ou renúncia, de acordo com o previsto no Regimento Interno.

Parágrafo Único - Os casos de substituição e perda de mandato dos conselheiros deverão estar previstos no Regimento Interno dos Conselhos Gestores.

\section{CAPÍTULO VI DAS DELIBERAÇÕES DO CONSELHO GESTOR}

Artigo $7^{\mathbf{0}}$ - As deliberações do Conselho Gestor dar-se-ão por maioria simples dos votos dos Conselheiros titulares presentes ou no exercício da titularidade, sendo que as reuniões serão realizadas com a presença da maioria de seus membros, com a lavratura e publicação de atas das discussões e deliberações, no prazo máximo de 07 (sete) dias.

Artigo $8^{\circ}$ - A nenhum membro do Conselho Gestor será permitido acúmulo de voto, resguardado o disposto no artigo antecedente.

Parágrafo Único - Em caso de empate na votação de deliberações do Conselho Gestor, ao Coordenador do Conselho caberá o voto de qualidade.

Artigo $9^{\circ}$ - As reuniões do Conselho Gestor serão públicas e abertas, tendo direito à voz todos os participantes. 
Artigo 10 - Fica assegurado aos membros dos Conselhos Gestores das Unidades de Saúde o direito de recorrer das deliberações dos mesmos ao Conselho Municipal de Saúde.

\section{CAPÍTULO VII}

\section{DA ELEIÇÃO DO CONSELHO GESTOR}

Artigo 11 - O mandato dos membros do Conselho Gestor será de 02 (dois) anos, admitindo-se uma única reeleição.

Artigo 12 - Os representantes dos servidores da unidade serão eleitos pela categoria, através de eleição direta e secreta dentre os seus pares.

Artigo 13 - Os membros indicados pela comunidade serão escolhidos através de eleição direta, que deverá ser organizada pela Coordenadoria de Participação Popular, juntamente com as associações de moradores dos bairros atendidos na respectiva unidade, aberta à população da área geográfica de sua abrangência, sob a coordenação da Secretaria Municipal de Saúde e do Conselho Municipal de Saúde.

Artigo 14 - O Conselho Gestor terá uma organização interna composta de Coordenador(a), Vice-Coordenador(a) e Secretário(a) Executivo(a).

Parágrafo Único - A escolha do(a) Secretário(a) Executivo(a) far-se-á por meio de eleição direta e secreta pelos conselheiros presentes, por maioria simples de votos.

Artigo 15 - O processo que elegerá o Conselho Gestor será conduzido por comissão eleitoral, escolhida pelo mesmo, especialmente composta para esse fim, que deverá iniciar seus trabalhos dois meses antes do término do mandato dos membros do Conselho.

forma:

Artigo 16 - A comissão eleitoral será composta da seguinte

I - Pelo encarregado técnico da unidade de saúde; e

II - Por, no mínimo, 04 (quatro) representantes de segmentos que compõem o Conselho.

Parágrafo Único - A Comissão eleitoral elegerá seu Presidente dentre os membros que a compõem, o que deverá ser registrado em ata, bem como os demais trabalhos pertinentes ao processo eleitoral.

Artigo 17 - A Comissão eleitoral convocará os segmentos que elegerão os representantes para o Conselho Gestor através de edital e outras formas de divulgação, com antecedência de 15 (quinze) dias. 
Artigo 18 - O Conselho Municipal de Saúde aprovará normas dispondo sobre a eleição de representantes dos segmentos dos servidores e dos usuários para a constituição dos Conselhos Gestores das Unidades de Saúde.

\section{CAPÍTULO VIII}

DAS ASSEMBLÉIAS

Artigo 19 - O Conselho Gestor reunir-se-á ordinariamente uma vez por mês e extraordinariamente quando convocado por seu Coordenador ou por 1/3 (um terço) de seus membros.

\section{CAPÍTULO IX \\ DAS DISPOSIÇÕES GERAIS}

atribuições, será concedido:

Artigo 20 - Ao membro do Conselho, no exercício de suas I - Acesso às instalações físicas da unidade, observadas as normas internas de funcionamento;

II - Acesso a todos os documentos de caráter administrativo ou técnico, com exceção daqueles que contenham informações de caráter pessoal de servidores ou matriculados, bem como dos prontuários médicos.

\section{CAPÍTULO X DAS DISPOSIÇÕES FINAIS E TRANSITÓRIAS}

Artigo 21 - Para a formação do primeiro Conselho Gestor das Unidades de Saúde o Conselho Municipal de Saúde, a Secretaria Municipal de Saúde e a Coordenadoria de Participação Popular do Município, criarão uma Comissão Especial que coordenará o processo de escolha de seus membros.

Parágrafo Único - Os casos omissos, não resolvidos pela Comissão Especial, serão remetidos ao Conselho Municipal de Saúde.

Artigo 22 - Esta Lei entrará em vigor na data de sua publicação, revogada as disposições em contrário. 
PREFEITURA DO MUNICÍPIO DE ARARAQUARA, aos 24 (vinte e quatro) dias do mês de agosto do ano de 2001 (dois mil e um).

\section{EDSON ANTONIO DA SILVA}

- Prefeito Municipal -

Publicada na Secretaria Municipal de Governo, na data supra.

\section{CLÉLIA MARA SANTOS FERRARI \\ - Secretária de Governo -}

Arquivada em livro próprio nº 01/2001. (“PC”). 
Anexo E: Alteração do art. $6^{\circ}$ da lei que instituiu o Conselho Gestor de Saúde 


\title{
0 \\ PREFEITURA DO MUNICÍPIO DE ARARAQUARA
}

\section{LEI $\mathrm{N}^{\circ} 6.308$}

De 30 de setembro de 2005

Altera o art. $6^{\circ}$, inciso XV, da Lei $n^{\circ} 5.655$, de 24 de agosto de 2001, que instituiu os Conselhos Gestores das Unidades de Saúde do Município.

\section{O PREFEITO DO MUNICÍPIO DE ARARAQUARA,}

Estado de São Paulo, no exercício de suas atribuições legais, e de acordo com o que aprovou a Câmara Municipal, em sessão ordinária de 27 de setembro de 2005, promulga a seguinte lei:

Art. $1^{\circ} \mathrm{O}$ artigo $6^{\circ}$, inciso XV, da Lei $\mathrm{n}^{\circ} 5.655$, de 24 de agosto de 2001, passa a vigorar com a seguinte redação:

“Art. $6^{\circ} \ldots$

XV - Integrar o Conselho Municipal de Saúde, indicando representantes em quantidade a ser definida em Conferência Municipal de Saúde, respeitada composição paritária do mesmo.”

Art. $2^{\mathbf{0}}$ Esta Lei entrará em vigor na data de sua publicação, revogadas as disposições em contrário.

PREFEITURA DO MUNICÍPIO DE ARARAQUARA, aos 27 (vinte e sete) dias do mês de setembro do ano de 2005 (dois mil e cinco).

\author{
EDSON ANTONIO EDINHO DA SILVA \\ Prefeito Municipal \\ DR. WAGNER CORRÊA
}

Secretário dos Negócios Jurídicos

Publicada na Secretaria Municipal de Governo, na data supra

\section{MÁRCIA APARECIDA OVEJANEDA LIA}

Secretária de Governo

Arquivada em livro próprio nº 01/2005 - (“PC”).

\section{Anexo F: Regimento Interno do Orçamento Participativo de Araraquara}




\section{REGIMENTO INTERNO DO ORCAMENTO PARTICIPATIVO 2004}

\section{CAPÍTULO I - Dos (as) Delegados (as).}

Art. $1^{\circ}$ - Cada região e cada plenária temática elegerá delegados(as) nas reuniões das subregiões do Orçamento Participativo, ficando garantida a representação mínima de um(a) delegado(as) por bairro, agrovila e loteamento da região ou temática, desde que presentes à Assembléia, na seguinte proporção:

De 01 a $10-01$ delegado (a);

De 11 a 20 - 02 delegados (as);

De 21 a 30 - 03 delegados (as); e assim sucessivamente.

O conjunto dos (as) delegados(as) eleitos (as) nas regiões e nas temáticas irá compor o Fórum Municipal de Delegados(as)

$\S 1^{\circ}$ - No processo preparatório das regiões realizar-se-ão reuniões das sub-regiões, onde serão hierarquizadas as demandas, e eleitos(as) os(as) delegados(as) na proporção acima.

\section{$\S 2^{\circ}$ - As plenárias temáticas terão em seu conjunto 6 (seis) temas:}

Pessoas Portadoras de Deficiências, •Negros, •Mulheres, •Idosos, •Juventude e •Plenária da Cidade.

Os(as) participantes das plenárias elegerão prioridades de forma hierarquizada e os delegados(as), na proporção do artigo $1^{\circ}$.

$\S 3 .^{\circ}$ - Para ter direito a voto no processo do Orçamento Participativo é necessário ser morador(a) da região e ter, no mínimo, 16 (dezesseis) anos de idade. Bem como o(a) cidadão(ã) que de alguma maneira esteja inserido(a) em espaços públicos ou privados e que tenham vínculo com a políticas estabelecias para a região desde que comprove mencionado vinculo.

$\S 4 .^{\circ}-$ Não há possibilidade de ser delegado(a) na região e na temática, ou em duas ou mais temáticas simultaneamente. 
$\S 5 .^{\circ}$ - As prioridades votadas nas plenárias temáticas deverão atender aos interesses da cidade como um todo.

$\S 6 .^{\circ}$ - Na temática dos(as) Portadores(as) de Deficiências, os(as) Delegados(as) a serem escolhidos para representantes dos(as) portadores(as) de deficiência mental/transtorno mental serão obrigatoriamente seus respectivos representantes legais.

§ 7..$^{\circ}$ - Na plenária temática dos portadores(as) de deficiências será garantido 1 um(a) delegado(a) para cada segmento de deficiência, nas seguintes modalidades: •visual, auditivo, físico, deficiência mental e transtorno mental.

$\S 8 .^{\circ}$ - Na temática dos(as) Idosos, no que se refere ao peso do voto, o COP delibera, nesta data, que será discutido e votado em plenária por delegados(as) da temática em 2004, para vigorar na data da mesma.

Art. $2^{\circ}$ - São atribuições dos(as) delegados(as):

a) organizar as reuniões e os(as) moradores(as) dos bairros (sub-regiões e regiões), para participarem das Reuniões e atividades do Orçamento Participativo;

b)divulgar as informações para a população sobre o funcionamento do Orçamento Participativo;

c) acompanhar o plano de Investimentos, desde a sua elaboração até a execução das obras;

d) compor as comissões que acompanharão a escolha das prioridades, bem como as comissões de obras, licitação, conselhos, e acompanhamento do orçamento na Câmara e execução orçamentária. As comissões poderão ser ampliadas com pessoas da comunidade, que participarem das reuniões do Orçamento Participativo.

e) acompanhar, em conjunto com os Conselheiros (as), e dar opiniões sobre dúvidas que eventualmente surjam no processo de elaboração do Plano de Investimentos da cidade;

f) acompanhar, em conjunto com os Conselheiros (as), e dar opiniões sobre o Regimento Interno do Conselho do Orçamento e sobre eventuais modificações no processo do Orçamento Participativo.

g) defender no Fórum de Delegados(as) as prioridades definidas no bairro e votar as prioridades regionais e temáticas. 
h) Deliberar, por intermédio do Fórum Municipal de Delegados(as),sobre a aplicação do disposto no artigo $4^{\circ}$ deste regimento.

i) comunicar com antecedência suas ausências das reuniões;

j) organizar, juntamente com a equipe do Orçamento Participativo, cursos para formação de delegados(as) e conselheiros(as) sobre orçamento público, licitação e finanças públicas.

k) Participar das reuniões do COP, tendo direito a voz e não a voto;

l) Reunir-se com os demais delegados(as) de sua região, uma vez por mês.

Art. $3^{\circ}$ - Não poderá ser delegado(a) o(a) detentor(a) de cargo em comissão na Administração Municipal, bem como o(a) detentor(a) de mandato eletivo no poder público (de qualquer esfera), porém, ambos(as), poderão votar nas plenárias de sua região como qualquer cidadão(ã).

\section{CAPÍTULO II}

Da perda do Mandato dos(as) Delegados(as).

Art. $4^{\circ}$ - Perderá o mandato o(a) delegado(a) que deixar de comparecer a três reuniões consecutivas ou a cinco intercaladas do Fórum Regional e Temático de Delegados(as), no período de um ano, salvo se apresentar motivo justo, a ser avaliado pelo próprio Fórum Regional de Delegados(as). Será garantido nas votações em plenárias das sub-regiões, a eleição de suplentes para delegados(as), caso exista a necessidade manifestada dos(as) presentes em plenária, em cada subregião.

\section{CAPÍTULO III}

Da composição do Conselho do Orçamento Participativo - COP.

Art. $5^{\circ}$ - O COP será composto por representantes da sociedade civil, desde que sejam delegados(as) do OP, na seguinte proporção: 
I - 2 (dois) conselheiros(as)titulares e 2 (dois) conselheiros(as)suplentes, eleitos(as) em cada uma das 8 (oito) regiões;

II - 2 (dois)conselheiros(as) titulares e 2 (dois) conselheiros(as) suplentes, em cada uma das 6 (seis) Plenárias temáticas do Orçamento do Participativo;

III - a equipe do Orçamento Participativo assessora o Conselho, porém não tem direito a voto.

Art. $6^{\circ}$ - Os(as) conselheiros(as) do Orçamento Participativo serão eleitos(as) pelos(as) participantes da Plenárias Regionais e das temáticas.

Art. $7^{\circ}$ - O mandato dos(as) conselheiros(as) é de 1 (um) ano, admitindo-se reeleição.

$\S 1^{\circ}$ - Os (as) conselheiros(as) poderão ter o seu mandato revogado a qualquer tempo, pelo Conselho do Orçamento Participativo.

$\S 2^{\circ}$ - O Conselho do Orçamento Participativo(as) deverá justificar a revogação do mandato, garantindo o direito de recurso do(a) Conselheiro(a) junto ao COP.

$\S 3^{\circ}$ - A revogação do mandato do(a) Conselheiro(a) ocorrerá por deliberação de 2/3 dos(as) Conselheiros (as).

\section{CAPÍTULO IV}

Das competências do Conselho (COP)

Art. $8^{\circ}$ - O COP é um órgão de participação direta da comunidade, tendo por finalidade propor, fiscalizar e deliberar sobre matérias referentes ao Plano de Investimentos do Orçamento Municipal de Araraquara, com base nas prioridades definidas no processo do OP.

Art. $9^{\circ}$ - Ao COP compete:

I - apreciar, emitir opinião e posicionar-se a favor ou contra a proposta de orçamento anual parte de investimentos - a ser enviada a Câmara de Vereadores(as); 
II - apreciar e emitir opinião sobre o conjunto das atividades constantes do orçamento anual apresentado pelo Executivo, em conformidade com o processo de discussão do Orçamento Participativo;

III - acompanhar a execução orçamentária anual e fiscalizar o cumprimento do Plano de Investimentos, opinando sobre eventuais incrementos, cortes ou alterações nos investimentos;

IV - opinar e decidir em comum acordo com o Executivo a metodologia adequada para o processo de discussão e definição do Plano de Investimentos e do processo do OP para o ano vindouro;

V - apreciar e emitir opinião sobre investimentos que o Executivo entenda como necessários para a cidade;

VI - dar ciência à população das deliberações tomadas pelo COP;

VII - participar e acompanhar todas as comissões juntamente com os(as) delegados(as);

VIII - avaliar e fiscalizar as demandas do ano anterior, principalmente as constantes do orçamento anual;

IX - reunir-se, trimestralmente, com os(as) delegados(as) das suas respectivas regiões, com o objetivo de discutir a atuação no processo do OP;

$\mathrm{X}$ - reunir-se, ordinariamente, uma vez por mês.

Art. 10 - Para serem aprovadas as deliberações do Conselho, metade mais uma das regiões e temáticas e/ou metade mais um dos(as) conselheiros(as) deverão estar presentes para aprovar os encaminhamentos prevalecentes. Caso não seja atingido o quorum acima estabelecido, em segunda convocação, após trinta minutos, a reunião acontecerá com o número de conselheiros(as) presentes. 
$\S 1^{\circ}$ - As resoluções aprovadas serão encaminhadas ao Executivo, que as acolherá ou vetará no todo ou em parte.

$\S 2^{\circ}$ - Vetada a resolução, a matéria retorna ao COP para nova apreciação ou votação;

$\S 3^{\circ}$ - Na hipótese de rejeição do veto, o que somente ocorrerá, por decisão mínima de 2/3 (dois terços) dos membros do COP, conforme quorum estabelecido, a matéria será novamente encaminhada ao Executivo Municipal.

\section{CAPÍTULO V - Da Organização interna do COP}

Art. 11 - O Conselho do Orçamento Participativo será composto por 1(um) coordenador(a), 1(um) vice-coordenador(a) e 1(um) secretário(a) executivo(a).

Parágrafo Único - A escolha do(a) Coordenador(a), Vice-Coordenador(a) e do(a) Secretário(a) executivo(a) far-se-á por meio de eleição direta e com voto aberto, pelos(as) conselheiros(as) presentes, por maioria simples de votos.

Art. 12 - As deliberações do COP dar-se-ão por maioria simples dos votos dos(as) conselheiros(as) titulares presentes ou no exercício da titularidade, sendo que as reuniões serão realizadas com a presença da maioria de seus membros, com a lavratura e publicação das atas das discussões e deliberações.

Parágrafo único - Caso não seja atingido o quorum estabelecido no caput deste artigo, em segunda convocação, após trinta minutos, a reunião acontecerá com o número de conselheiros(as) presentes.

Art. 13 - A nenhum membro do COP será permitido o acúmulo de voto, resguardado o disposto no artigo antecedente.

Art. 14 - Perderá o mandato o(a) conselheiro(a) que deixar de comparecer a 03 (três) reuniões consecutivas ou a 05 (cinco) intercaladas, no período de um ano, salvo se apresentar motivo justo, a ser avaliado pelo COP. 
Art. 15 - Ocorrendo perda do mandato pelo(a) conselheiro(a)a vaga será ocupada pelo seu suplente.

Art. 16 - O(a) Conselheiro(a) titular que não puder comparecer as reuniões deverá comunicar o seu suplente com 2 (dois) dias de antecedência.

\section{CAPÍTULO VI - Das Reuniões.}

Art. 17 - O COP se reunirá ordinariamente uma vez por mês e extraordinariamente quando convocado por seu Coordenador(a) ou por 1/3 (um terço) de seus membros.

$\S 1^{\circ}$ - Uma vez protocolado o requerimento solicitando a reunião extraordinária, o(a) coordenador(a) terá o prazo de 03 (três) dias úteis para expedir a convocação e realizar a reunião.

$\S 2^{\circ}$ - O(a) secretário(a) executivo(a) deverá lavrar as atas das reuniões do COP, fazendo nela constar as discussões e deliberações, tornando-a pública, bem como realizar o controle de freqüência dos presentes e fornecer o material necessário para a reunião.

$\S 3^{\circ}$ - As datas e os horários das reuniões ordinárias serão fixadas, por consenso, na primeira reunião ordinária de cada semestre e enviado Cronograma para todos(as) os(as) conselheiros(as).

$\S 4^{\circ}$ - O coordenador(a), juntamente com o secretário(a) executivo(a) expedirá, obrigatoriamente, convocação, para os membros titulares e suplentes, com a devida pauta, 05(cinco) dias úteis antes das reuniões ordinárias.

Art. 18 - No início de cada reunião será estipulado por consenso o tempo de sua duração, podendo ser prorrogado, desde que haja o quorum mínimo exigido.

Art. 19 - As reuniões do COP serão compostas por:

I - expediente;

II - Ordem do dia.

Art. 20 - O expediente obedecerá ao seguinte procedimento: 
I - discussão e aprovação da ata anterior;

II - comunicações do coordenador (a);

III - comunicações dos membros.

Art. 21 - A Ordem do Dia deverá compor-se dos assuntos constantes da pauta para deliberação.

Art. 22 - Os (as) suplentes que não estiverem substituindo titulares, poderão participar das reuniões com direito a voz.

Art. 23 - As reuniões do COP serão públicas. Toda pessoa tem direito de assistir as reuniões, podendo manifestar-se a cada assunto.

Art. 24 - Caberá à Comissão executiva a elaboração da pauta que comporá a Ordem do dia das reuniões do COP considerando:

I - propostas do Plenário feitas em reuniões anteriores;

II - matérias pendentes constantes da Ordem do dia das reuniões anteriores;

III - matéria apresentada por qualquer membro do Conselho e dirigida ao Coordenador (a).

Parágrafo único - Em reuniões ordinárias, por decisão do plenário, poderão ser incluídos para deliberação, assuntos que não constem

da ordem do dia.

Art. 25 - O COP deliberará por maioria simples de seus membros, por meio de votação aberta, tendo cada membro o direito a um voto.

Art. 26 - O(a) Coordenador(a) colocará, obrigatoriamente, em votação toda matéria depois de esgotadas as discussões.

\section{CAPÍTULO VII}

Das Disposições Finais 
Art. 27 - Os(as) delegados (as) e conselheiros(as) não receberão qualquer tipo de remuneração por sua participação nas atividades do Orçamento Participativo.

Art. 28 - O presente regimento vigorará a partir das modificações feitas pelo COP e início do OP de 2005.

Art. 29 - Os casos omissos deste regimento serão decididos pelo COP.

Araraquara, 30 de Março de 2004.

CONSELHO DO ORÇAMENTO PARTICIPATIVO 
Anexo G: Roteiro de Entrevista 


\section{ROTEIRO DE PERGUNTAS PARA A ENTREVISTA}

1. Você participava de algum movimento ou entidade antes de 2001?

2. E agora você participa em quê? Por que participa?

3. Em que essa administração ajudou na sua atual atuação?

4. O que fez com que você se interessasse em participar desses espaços?

5. O OP tem haver com isso? Ele colabora com esse interesse em participar? Como? Por quê?

6. O que você entende por cidadania?

7. Você acha importante participar de conselhos, associações, partidos políticos, sindicatos? Por quê?

8. Os espaços abertos de participação popular pela atual Administração estimulam o envolvimento do cidadão com o que é público? Como isso acontece?

9. Você se sente estimulado em participar destes mecanismos de controle social ou a ajudar na questão do que é público? 